\title{
6306 Sayılı Kanun Kapsamında Riskli Yapılarda Pay (Hisse) Satışı
}

\author{
Share Sale in Hazardous Structures Under Law No. 6306
}

\author{
Hüseyin Melih Çakır ${ }^{*}$ (D), Barış Ülker ${ }^{* *}$ (iD)
}

\section{öz}

6306 sayılı Afet Riski Altındaki Alanların Dönüştürülmesi Hakkında Kanun, büyük bölümü deprem kuşağında yer alan ülkemizde deprem kaynaklı riskleri mümkün olan en süratli şekilde asgari düzeye indirmeyi amaçlamaktadır. Riskli olduğu belirlenen yapı ve alanlar, bu Kanun sayesinde, malikler arasında oybirliği bulunmasa dahi nitelikli çoğunluk kararı ile kentsel dönüşüme tabi tutulabilmektedir. Bu kapsamda söz konusu Kanunla, çeşitli nedenlerle kentsel dönüşüm kararına muhalif kalan paydaşların paylarının idare aracılığıyla satılabilmesi mümkün kılınmıştır. Ancak bu payların satışına ilişkin mevzuatta öngörülen şartlar ve usul konusunda bazı hukuki belirsizlikler bulunmaktadır. $\mathrm{Bu}$ belirsizlikler, Kanun'un "depreme süratli şekilde hazırlanma” amacına sekte vurmasının yanı sıra, kentsel dönüşüm umuduyla riskli yapılarını tahliye etmek zorunda kalan vatandaşların mülkiyet haklarını uzun yıllar olumsuz etkileyebilmektedir. Bu çalışmada, riskli yapılarda pay satışının konusu, şartları ve usulüne ilişkin mevzuatın yazımından veya başka sebeplerle ortaya çıkan gri alanlar üzerinde durularak, uygulamada yaşanan veya yaşanması muhtemel hukuki problemlere çözüm önerileri getirilmek istenmektedir.

Anahtar Kelimeler: Pay Satışı, Kentsel Dönüşüm, Riskli Yapı, 6306 sayılı Kanun, Deprem, Mülkiyet Hakkı

\section{ABSTRACT}

Law on the Transformation of Areas under Disaster Risk ["Law No. 6306”] intends to reduce the risks arising from earthquakes as rapidly as possible in Turkey, which is mostly located in an earthquake zone. Structures and areas that are determined to be hazardous can be subjected to urban transformation with a majority decision of the owners under the Law, even if there is no unanimity among the owners. As a matter of fact, the Law stipulates the shares of minority stakeholders - who are dissenting to the decision taken by the majority sought by the Law - sold through the administration. However, there are uncertainties about the statutorily mandated conditions and procedure for the sale of owners' shares. In addition to obstructing the Law's purpose of "Preparation promptly for an earthquake beforehand", these uncertainties may have a long-term negative impact on the property rights of residents who have been forced to evacuate hazardous structures in the hope of urban transformation. This study will highlight gray areas stemming from the writing of laws regarding subject, conditions, and procedure of the sale of shares in terms of hazardous structures or other reasons; so, with this study, it is intended to recommend provide solutions to these legal issues that have arisen or are expected to arise in this area of practice.

Keywords: Share Sale, Urban Transformation, Hazardous Structure, Law No. 6306, Earthquake, Property Right 


\section{GíRiş}

Neredeyse her yıl yaşanan irili ufaklı doğal afetler, ülkemizin talihsiz kaderi olarak karşımıza çıkmaktadır. Bu afetlerin ortaya çıkardığı sonuçların ağırlığı, çoğu zaman afetin büyüklügüule değil, afetin gerçekleştiği alan veya bu alanda bulunan yapıların durumlarıyla bağlantılıdır. Özellikle ülkemizde yaşanan depremlerin ortaya çıkardığı ağır sonuçların, yapıların kalitesizliğinin bir çıktısı olduğu her platformda dile getirilmektedir. Deprem kuşağında yer alan ülkemizde, geçmişte yaşanan depremlerin son büyük deprem olmadığı da bilimsel bir gerçektir. Öte yandan, başta İstanbul olmak üzere ülkemizde şiddetli bir depremin gerçekleşmesi ihtimalinde, afet riski altındaki yapılara bağlı olarak kişilerin yaşama haklarının büyük bir tehlike altında kalacağını öngörmek hiç de zor değildir.

Kanun koyucu, böylesine olumsuz bir senaryonun önüne geçmek amacıyla, 6306 sayılı Afet Riski Altındaki Alanların Dönüştürülmesi Hakkında Kanun’u [“6306 sayılı Kanun”] ihdas etmiş; sonrasında, bu kanunun uygulanmasını göstermek üzere, 6306 sayılı Kanun’un Uygulama Yönetmeliği [“Uygulama Yönetmeliği”] ${ }^{2}$ yürürlüğe konmuştur. Bu mevzuat, riskli yapı ve alanları depreme hazır hale getirme amacı gütmekte ve günümüz kentsel dönüşüm uygulamalarının esasını oluşturmaktadir.

6306 sayılı Kanun, afet riski altında bulunan, i. riskli alan; ii. riskli yapı ve iii. rezerv yapı alanlarını kapsamakla birlikte; bu çalışmanın konusu 'riskli yapılar'la sınırlıdır. Kanun'da, Kanun'un ihdas edilme amacı doğrultusunda riskli yapılarda gerçekleştirilecek kentsel dönüşüm uygulamalarını kolaylaştırıcı düzenlemeler bulunmaktadır. Bu doğrultuda, riskli yapılarda gerçekleştirilecek uygulama işlemleri için $2 / 3$ çoğunluk yeterli görülmüştür. Şu halde, kentsel dönüşüme muhalif $1 / 3$ azınlık paydaş(lar)1n payına ne olacağı sorusu akla gelmektedir. Kanunda, riskli yapıların bulunduğu parsellerde hisseleri oranında paydaşların en az 2/3 çoğunluğu ile alınan karara katılmayan maliklerin arsa paylarının satışının gerçekleştirilebileceği ifade edilmiştir. Mezkûr mevzuatta öngörülen şartların sağlanması halinde ise, Uygulama Yönetmeliği'nin 15/A maddesinde gösterilen usul dairesinde muhalif paydaşın payının satışı mümkün kılınmıştır. Şu hâlde, pay satışı müessesesi, kentsel dönüşüm uygulamalarının gerçekleştirilmesinin önemli bir aracı olarak karşımıza çıkmaktadır. Ancak gerek pay satışı için aranan şartlara gerekse de pay satış usulüne ilişkin kurallar, yeterli açıklığa sahip olmaması nedeniyle hukuki sorun yaratmaya aday niteliktedir. Zira, mevzuatın lafzı son derece karışıktır.

Öte yandan, 6306 sayılı Kanun ve Uygulama Yönetmeliği’nin, kısa sayılabilecek zaman diliminde fazlaca değişikliğe uğraması da var olan karmaşayı her defasında biraz daha artırmıştır. 6306 sayılı Kanun ve Uygulama Yönetmeliği ihdas tarihinden itibaren defalarca kapsamlı değişikliğe uğramıştır. 'Kervan yolda düzelir' anlayışıyla hareket edilerek, uygulamada ortaya çıkan ihtiyaç ve/ veya eksiklikler nedeniyle mevzuatta sıkça değişikliğe gidilmesi, 6306 sayılı Kanun uygulamasının hem yargı hem de idare açısından - yeknesaklaşmasını engellemiş; bu durum, hukuki belirlilik ve

1 Afet Riski Altındaki Alanların Dönüştürülmesi Hakkında Kanun, Kanun Numarası: 6306, Kabul Tarihi: 16.05.2021, RG 31.05.2012/28309.

26306 Sayılı Kanunun Uygulama Yönetmeliği, RG 15.12.2012/28498. 
öngörülebilirliğin sağlanmasının önüne geçmiştir. 6306 sayılı Kanun kapsamında riskli yapılarda pay satışı müessesesi de bu sonuçlardan nasibini almıştır.

Bu çalışmada, 6306 sayılı Kanun kapsamında yer alan riskli yapılarda uygulama işlemlerine ilişkin olarak alınacak kararlara muhalif kalan maliklere ait pay (hisse) satışının konusu, şartları, usulü, sonuçları ve satışa karşı başvuru yolları gibi hususlar üzerinde durulacaktır. Böylece, güncel mevzuat ve yargı kararları ışığında, pay satışı müessesenin hukuki çerçevesi çizilmeye çalışılacaktır. Bu sayede, en azından riskli yapılarda pay satış müessesesinin 6306 sayılı Kanun'un karmaşasından sıyrılması, 6306 sayılı Kanun’un afet riski altındaki riskli yapılarda "süratli dönüşüm sağlama" amacının gerçekleştirilmesi, uygulamada ve yargı kararlarındaki farklılıkların önüne geçilmesi ile kişilerin mülkiyet haklarının ihlal edilmesinin önlenmesi amaçlanmaktadır.

\section{GENEL OLARAK 6306 SAYILI KANUN VE KENTSEL DÖNÜŞÜM}

6306 sayılı Kanun, günümüz kentsel dönüşüm uygulamalarının ana kaynağı niteliğindedir ${ }^{3} . \mathrm{Bu}$ Kanun, kentsel dönüşüme ilişkin daha önce çıkarılan mevzuata ${ }^{4}$ göre çok daha kapsayıcı nitelik taşımaktadır. Kanun'un 1.maddesinde, "(b)u Kanunun amacl; afet riski altındaki alanlar ile bu alanlar dışındaki riskli yapıların bulunduğu arsa ve arazilerde, fen ve sanat norm ve standartlarına uygun, sağlıklı ve güvenli yaşama çevrelerini teşkil etmek" olarak belirlenmiştir ${ }^{5}$. Bu Kanun’la kanun koyucu, olası afetler sonucunda can ve mal güvenliğinin zarar görmesine neden olacak riskleri kaldırmayı, kentsel alanların ve yapıların planlama ve şehircilik ilkelerine uygunluğunun sağlanmasını ${ }^{6}$, yani kentsel dönüşüm $\ddot{\ddot{i}}^{7}$ hedeflemiştir.

Her ne kadar 6306 sayılı Kanun'un başlı̆̆ında "afet" kavramına yer verilmiş olsa da bu Kanun incelendiğinde, esas odak noktasının deprem afeti olduğu görülecektir. Bilindiği ve müteaddit defalar

3 Gül Üstün, Kentsel Dönüşüm Hukuku (1. Bası, On İki Levha Yayıncılık 2014) 128.

4 Bkz 6306 sayılı Kanun’un yürürlüğe girmesinden önce kentsel dönüşümü konu edinen düzenlemeler ile bu düzenlemelere ilişkin değerlendirmeler hakkında $\boldsymbol{b} \boldsymbol{k} z$ Melikşah Yasin, 'Kentsel Dönüşüm Uygulamalarının Hukuki Boyutu' Türkiye Barolar Birliği Dergisi (2005) 18(60) 105, 116 vd.; Selami Demirkol ve Zuhal Bereket Baş, 'Kentsel Dönüșümün, 6306 Sayılı Yasa Kapsamında Hak ve Özgürlükler Açısından Ele Alınması’ (2013) (108) Türkiye Barolar Birliği Dergisi 23, 4042 .

56306 sayılı Kanun'un ihdas edilmesindeki ekonomik, hukuki, sosyal ve siyasi nedenler için $\boldsymbol{b} \boldsymbol{k} z$ Esin Gürsel, Kentsel Dönüşüm (1. Bası, Adalet Yayınları 2018) 65 vd.

6 Osman Oy ve Selahattin Nazik, Kentsel Dönüşüm Kapsamında Rezerv Yapı Alanı - Riskli Alan ve Riskli Yapılar (1.Bası, Beta 2014) 46. Bu yönde ayrıca bkz Yargıtay 14 HD, E 2017/1069 K 2018/3038, 17.04.2018; Yargitay 3 HD E 2018/4855 K 2019/8655, 04.11.2019. (Bundan sonra Yargıtay kararları için ayrıca bir kaynak belirtilmeyen hallerde, kararların 'Lexpera' bilgi bankasından alındığı kabul edilecek ve ayrıca kaynak gösterilmeyecektir).

7 "Kentsel dönüşüm, farklı nedenlerden ötürü zaman içerisinde eskimiş, köhneleşmiş, yıpranmış ya da kimi durumlarda terk edilmiş, vazgeçilmiş kent dokusunun, günün sosyo-ekonomik ve fiziksel koşulları göz önünde tutularak değiştirilmesi, dönüştürülmesi, ıslah edilmesi ve yeniden canlandırılarak kente kazandırılmasıdır”. Anayasa Mahkemesi, E 2010/82 K 2012/159, 18.10.2012. (Bundan sonra Anayasa Mahkemesi kararları için ayrıca bir kaynak belirtilmeyen hallerde, kararların Anayasa Mahkemesi’nin resmi internet sitesinde yer alan 'Kararlar Bilgi Bankası'ndan alındığı kabul edilecek ve ayrıca kaynak gösterilmeyecektir).

8 Jeolojik bir afet olan depremin yanı sıra sel gibi klimatik afetler, salgın gibi biyolojik afetler, terör gibi sosyal afetler ve nükleer kaza gibi teknolojik afetler vb. vardır. Nitekim mevzuatta da bu şekilde tanımlanmıştır. Afet ve Acil Durum Müdahale Hizmetleri Yönetmeliği, Bakanlar Kurulu Kararının Tarihi: 26.08.2013 / 2013/5703, Dayandığ Kanunun 
acı şekilde tecrübe edildiği üzere Türkiye bir depremler ülkesidir ${ }^{9}$. Türkiye'nin 1999 depremine benzer büyük yeni bir depreme hazır olmadığı resmi makamlar başta olmak üzere, düzenli şekilde gündeme getirilmektedir.

6306 sayılı Kanun'un gerekçesinde de ${ }^{10}$ yukarıda açıklananlara paralel şekilde Türkiye’nin deprem riski altında olduğu; buna rağmen mevcut yapıların büyük kısmının muhtemel afetlere karşı dayanıklı olmadıkları ve orta şiddetteki bir depremde bile ağır derecede hasar görüp yıkıldıkları ifade edilmiştir. İşte 6306 sayılı Kanun'la ${ }^{11}$ beraber, mümkün olan en kısa sürede risk altında bulunan yapı ve alanları dönüştürmek ${ }^{12}$ ve Türkiye'yi olası afetlere, depremlere hazır hale getirmek istenmiştir. 6306 sayılı Kanun'un kapsamı da bu doğrultuda belirlenmiştir ${ }^{13}$. Kanun, özel mülkiyette bulunan taşınmazlar üzerindeki yapıların, depreme dayanıklılık testlerine tabi tutulmasını, bu testler sonucunda riskli bulunan yapıların yıkılarak yerlerine afetlere dayanıklı yeni yapıların inşa ettirilmesini öngörmekte ${ }^{14}$; üzerindeki zeminin özelliği nedeniyle afete maruz kalacak alanların tahliyesini ve bu alanlarda yaşayan kişilerin yeni yapılacak yerleşim alanlarına naklini konu almaktadır ${ }^{15}$.

"Şüphesiz bunda riskli yapı maliklerinin önemli kişisel menfaatleri bulunmaktadır16”. Ancak bu menfaatin her durumda tüm malikler açısından özdeş olduğunu söylemek zordur. Kentsel dönüşüm uygulamalarıyla elde edilmek istenen menfaat (yarar) ile mülkiyet hakkı17 zaman zaman karşı karşıya

Tarihi : 29.05.2009/5902, RG 18.12.2013/28855’nin 4.maddesine göre afet, “Toplumun tamamı veya belli kesimleri için fiziksel, ekonomik ve sosyal kayıplar doğuran, normal hayatı ve insan faaliyetlerini durduran veya kesintiye uğratan, etkilenen toplumun baş etme kapasitesinin yeterli olmadı̆̆ı doğal, teknolojik veya insan kaynaklı olayları," ifade eder.

9 Türkiye’nin yüzölçümünün \%92'si 1. 2. 3. ve 4. derece deprem bölgesinde bulunmaktadır; toplam nüfusunun \%70'i 1. ve 2. derece deprem bölgesinde yer almaktadır; nüfusunun \%23’ü tarihsel süreç içinde doğrudan bir afete maruz kalmıştır. <https://webdosya.csb.gov.tr/db/altyapi/icerikler/r-skl-_alan_ilan-_ve_uygulama_klavuzu-201.802.22090434.pdf:> Erişim Tarihi: 3 Ağustos 2021

$10<$ https://www2.tbmm.gov.tr/d24/1/1-0569.pdf> Erişim Tarihi: 27 Ağustos 2021

116306 sayılı Kanun’a ilişkin değerlendirmeler için $\boldsymbol{b} \boldsymbol{k} z$ Ergun Özsunay, '6306 Sayılı Kanun ve Kentsel Dönüşüm Uygulamalarına İlişkin Düşünceler’ İstanbul Barosu Dergisi (2014) 88(6) 15, 15-52.

12 "Anayasa'nin 5. maddesinde, "Devletin temel amaç ve görevleri, [...] kişilerin ve toplumun refah, huzur ve mutluluğunu sağlamak; [...] insanın maddi ve manevi varlı̆ı̆ın gelişmesi için gerekli şartları hazırlamaya çalışmaktır." denilmiştir. Anayasänın 56. maddesinde ise "herkesin, sağlıkh ve dengeli bir çevrede yaşama hakkına sahip olduğu belirtilmiş; çevreyi geliştirmek, çevre sağlığını korumak ve çevre kirlenmesini önlemek” Devletin ve vatandaşların ödevleri arasında sayılmıştır: "Afet riski altındaki alanların dönüştürülmesi, Anayasa'nn anılan maddelerinde Devlete yüklenen ödevlerle ilgilidir". Anayasa Mahkemesi, E 2012/87 K 2014/41, 27.02.2014.

136306 sayılı Kanun i. riskli alanları; ii. riskli yapıları ve iii. rezerv yapı alanlarını kapsamaktadır. Bu kavramlar, 6306 sayılı Kanun'un 2.maddsinde tanımlanmıştır.

Madde 2: "Bu Kanunun uygulanmasinda; [...]

c) Rezerv yapı alanı: Bu Kanun uyarınca gerçekleștirilecek uygulamalarda yeni yerleșim alanı olarak kullanılmak üzere, TOKİnin veya İdarenin talebine bağh olarak veya resen Bakanlıkça belirlenen alanları,

c) Riskli alan: Zemin yapısı veya üzerindeki yapılaşma sebebiyle can ve mal kaybına yol açma riski taşıyan, Cumhurbaşkaninca kararlaştırılan alanı,

d) Riskli yapı: Riskli alan içinde veya dışında olup ekonomik ömrünü tamamlamış olan ya da yıkılma veya ağır hasar görme riski taşıdığı ilmî ve teknik verilere dayamilarak tespit edilen yapıyı, [...] ifade eder".

14 Suat Şimşek, Türkiye’de Kentsel Dönüşüm Uygulamaları (4. Bası, Seçkin Yayınclık 2016) 25.

15 Üstün, Kentsel Dönüşüm Hukuku (1. Bası, On İki Levha Yayıncılık 2014) (n 3) 131.

16 Anayasa Mahkemesi, E 2012/87 K 2014/41, 27.2.2014.

17 Anayasa Mahkemesi, E 2016/133 K 2017/155, 15.11.2017: “Mülkiyet hakkı; kişiye başkasııın hakkına zarar vermemek ve kanunların koyduğu sinırlamalara uymak koșuluyla sahibi olduğu şeyi dilediği gibi kullanma, ürünlerinden 
gelebilmekte; dönüşüm, her zaman kolaylıkla gerçekleş(e)memektedir. Nitekim bu çalışmanın konusunu oluşturan "pay satışı" müessesesi de bu karşıtllğın ve zorluğun bir sonucu olarak ortaya çıkmıştır.

\section{SATIŞIN KONUSU: PAY (HISSE)}

6306 sayılı Kanun ve Uygulama Yönetmeliğìnin farklı noktalarında ${ }^{18}$ kanun koyucunun ayrı ayrı "pay", "arsa payı" ve "hisse" kavramlarına yer verdiği görülmektedir. Pay, arsa payı ve hisse kavramlarının aynı anda kullanılmasının bir terminoloji karmaşasına yol açtığı aşikardır. Bu durum, ister istemez, kavramların farklı bir anlam ifade edip etmediği; farklı bir anlam ifade ediyorsa, bu kullanımın sebep(ler)inin ve sonuçlarının ne olduğu gibi soruları akla getirmektedir. Söz konusu soruların cevabı, kavramların ayrı ayrı kullanımının bilinçli bir tercih olup olmadığını tespite yaramanın yanı sıra, çalışmada ele alınan satışın konusunu hangisinin oluşturduğunu da ortaya çıkaracaktır. Bunun için öncelikle kavramların ne anlama geldiklerinin incelenmesi gerekmektedir.

Pay, konumuz bakımından birlikte sahip olunan mülkiyete 'katılma' yetkisi sağlayan, bünyesinde haklar ve borçlar barındıran bir kavramdır. Bu pay sayesinde paydaşlar TMK md.688’te belirtilen "malik hak ve yükümlülüklerine" sahip olurlar. Kelime anlamı olarak, "pay" ve "hisse" eş anlamlıdır19. Gerçekten de riskli yapı kararına konu taşınmazda hak sahibi olan malikler arasında, müşterek (paylı) mülkiyet söz konusu değilse; pay ve hisse, 6306 sayılı Kanun sistematiğinde kelime anlamına uygun şekilde kullanılmaktadır.

Ancak riskli yapı malikleri içerisinde müşterek (paylı) mülkiyet rejimine tabi olanlar varsa; kanun koyucu, bu maliklerin taşınmazdaki pay(lar)ı üzerinde sahip oldukları hisselerini esas almaktadır. Gerek uygulama işlemlerine karar verme asgari nisabı olan paydaşların 2/3'ünün hesabında, gerekse de satışın konusunu oluşturması bakımından; müşterek mülkiyete konu payın tamamı değil, her biri kendi payı bakımından malik hak ve yükümlülüklerine sahip olan paydaşların pay üzerindeki hisseleri dikkate alınmaktadır. 6306 sayılı Kanun kapsamında alınan kararlara katılan müşterek mülkiyet paydaşları, hisseleri kapsamında dönüşüm uygulamaları sonrasında taşınmazdaki mülkiyet haklarını muhafaza ederken; karara katılmayan(lar)ın hisseleri ise satışa konu edilebilmektedir. Bu durumda satışın konusunu ise, payın tamamı değil, müşterek maliklerden uygulamaya ilişkin karara katılmayan(lar)ın hisseleri oluşturmaktadır.

Böylece, 6306 sayılı Kanun uyarınca, riskli yapı olarak belirlenen ve hızlı bir şekilde dönüşüme tabi tutulması arzulanan binada gerçekleştirilecek uygulama işlemlerinde, 4271 sayılı Türk Medeni Kanunu ${ }^{20}$ yararlanma ve tasarruf olanağı veren bir haktır".

18 "Pay" kavramının geçtiği maddeler için bkz 6306 Sayılı Kanun md.6; Yönetmelik md.13, md.15, md.15/A. "Arsa payı" kavramının geçtiği maddeler için: $b \boldsymbol{k z} 6306$ Sayılı Kanun md.6, md.6/A; Yönetmelik md.7, md.13, md.15, md.15/A.

19 Türk Dil Kurumu: "Pay - 1. isim Birden fazla kişi arasında bölüşülmüş bir bütünden, bu kişilerin her birine düşen bölüm, hisse." <https://sozluk.gov.tr/> Erişim Tarihi: 25 Eylül 2021; Türk Hukuk Kurumu, Türk Hukuk Lügatı, (1. Bası, Başbakanlık Basımevi 1991) (129), 278; Nişanyan Sözlük: "Hisse - 1. Pay [...]" <https://www.nisanyansozluk. com/?k=hisse $>$ Erişim Tarihi: 25 Eylül 2021. 
[“TMK”] hükümleri uyarınca paylı mülkiyette yönetim ve tasarrufa ilişkin ortaya çıkması muhtemel bir ön sorun’un önüne geçilmekte; tabir-i caizse müstakbel sorun bypass edilmektedir. Ayrıca, her bir paydaşın pay üzerindeki hissesine karşılık gelecek şekilde 6306 sayılı Kanun kapsamındaki uygulama işlemlerinin karar alma süreçlerine katılmaları sağlanarak, taşınmazda mülkiyet hakkına sahip olan herkesin, mülkiyetin bahşettiği yetkileri kullanmasına imkân tanınmaktadır.

Arsa payı kavramı ise 634 sayılı Kat Mülkiyeti Kanunu" ${ }^{21}$ ["KMK”] md.2/d ile Toplu Yapılarda Kat Mülkiyeti ve Kat Mülkiyeti Tesisine Dair Yönetmelik ${ }^{22}$ md.4/b’de tanımlanmıştır. Paralel düzenlemelere sahip olan bu mevzuata göre arsa payı, arsanın kanunda yazılı esasa göre bağımsız bölümlere tahsis edilen ortak mülkiyet paylarına denilmektedir. Buna göre, arsa payı kavramının, kat mülkiyetinin veya kat irtifakının kurulu olduğu yapılarda söz konusu olduğunu söylemek yanlış olmayacaktır ${ }^{23}$. Şu hâlde, kat mülkiyetine/irtifakına özgülenen arsa payı kavramı, paylı mülkiyete dair bir kavram olan pay kavramından ${ }^{24}$ tamamen bağımsız olmamakla birlikte ${ }^{25}$, daha farklı bir anlama sahiptir.

Görüldüğü üzere, arsa payı ve pay kavramları birbirinden farklı anlamlar ihtiva etmektedir. Bu noktada kanun koyucunun hem arsa payı hem de pay kavramını zikretmesinin anlamlandırılması gerekmektedir. Yukarıda da ifade edildiği üzere arsa payı, kat mülkiyetinin/irtifakının kurulu olduğu yapılarda söz konusu olabilmektedir ${ }^{26}$. Şu hâlde arsa payı, kat mülkiyeti/irtifakının halihazırda var olduğu; henüz yıkımı gerçekleşmemiş taşınmazlar açısından söz konusu olabilir. KMK’nın arsa payı ve bağımsız bölüm arasında kurduğu sıkı bağ nedeniyle, yapı yıkılarak kat mülkiyeti/irtifakı terkin edilmeksizin arsa payının satışı söz konusu olamaz. Bu terkin gerçekleştikten sonra ise bir 'arsa payı satışı’ndan değil; aslında 'pay satışı’ndan bahsedilebilir. Zira ortada kat mülkiyeti/irtifakı bulunmadığı için, KMK kapsamında ona bağlı bir arsa payından da söz edilemez ${ }^{27}$. Şu hâlde, 6306 sayılı Kanun kapsamında satışın konusunu, pay veya paydaki hissenin oluşturduğunu söylemek mümkündür.

21 Kat Mülkiyeti Kanunu: 634, Kabul Tarihi: 23.06.1965, RG 02.07.1965/12038.

22 Toplu Yapılarda Kat Mülkiyeti ve Kat Mülkiyeti Tesisine Dair Yönetmelik, RG 16.08.2008/26969.

23 İmar Kanunu, [“ÍK”] Kanun Numarası: 3194, Kabul Tarihi: 03.05.1985, RG 09.05.1985/18749, İmar Kanunu'na aykır1 inşa edilmiş yapılarda kat mülkiyetinin kurulamayacağına ilişkin olarak bkz Yargıtay 23 HD, E 2014/10194 K 2015/5890, 15.09.2015.

24 Birlikte mülkiyetin bir türü olan elbirliğiyle mülkiyette paylı mülkiyetten farklı olarak payın söz konusu olmayacağına ilişkin bkz Mustafa Kemal Oğuzman, Özer Seliçi ve Saibe Oktay Özdemir, Eşya Hukuku (18. Bası, Filiz Yayıncılık 2015) 348.Nitekim TMK md.701/2 göre de "(e)lbirliği mülkiyetinde ortakların belirlenmiş payları olmayıp her birinin hakkı, ortaklı̆̆a giren malların tamamına yaygındır”. Şu hâlde, elbirliğiyle mülkiyetin söz konusu olduğu durumlarda, 6306 sayılı Kanun kapsamında işlem tesisi için, TMK md.702 çerçevesinde hareket edilmesi veya TMK md.703 uyarınca elbirliğiyle mülkiyetin sona erdirilmesi gerektiği söylenebilecektir.

Buna karşın Jale G. Akipek, Turgut Akıntürk ve Derya Ateş, Eşya Hukuku (2. Bası, Beta 2018) 390’a göre vergi vb. konularda yine de paydan söz edilmesi gerekmektedir.

25 Etem Sabâ Özmen ve Ahmet Ayar, 'Kentsel Dönüşüm Uygulamalarında Eski Arsa Payından Paylı Mülkiyete ve Yeni Arsa Payına Uzanan Süreçte Yanılgılar’ Türkiye Barolar Birliği Dergisi (2021) (156) 107, 139-163. Yazarlar, arsa payı kavramın, pay kavramına dayalı olduğunu söylemekte ve bunu şu şekilde formüle etmektedirler: "Arsa payı yalnızca kat mülkiyeti elbisesi giymiş pay kavramı ile birlikte vücut bulur." ibid 142.

26 Etem Sabâ Özmen ve Mehmet Şengül, Kentsel Dönüşümde Kat Mülkiyeti Uygulamaları ile Sınırlı Ayni Haklar ve Şerhler (1.Bası, On İki Levha Yayıncılık 2018) 171.

27 Bu husustaki açıklamalar hakkında $\boldsymbol{b} \boldsymbol{k} z$ "Yapının Yıkılmış Olması" başlığımız. 
Peki 'arsa payı' kavramının kullanılmasının sebebi nedir? Bir dairenin arsa payının, konumu ve büyüklüğüne göre diğer dairelerle farklılık gösterebileceği bilinmektedir ${ }^{28} 29$. Bu husus, payın gerçek değeri üzerinden satılmasına doğrudan etki edecek olması nedeniyle mülkiyet hakkını da yakından ilgilendirmektedir. Bu açıklamalardan hareketle, kat mülkiyeti/irtifakı kurulu taşınmazlarda da satışın konusunu 'pay’ın (hissenin) oluşturduğunu; ancak satışa konu edilecek payın ve değerinin, öncesindeki arsa payı üzerinden hesaplanacağını söylemek yanlış olmaz.

\section{PAY SATIŞININ ŞARTLARI}

6306 sayılı Kanun kapsamında gerçekleştirilecek pay satışı, belirli şartların tamamlanmasının ardından, bir idari usul neticesinde söz konusu olur. Bir diğer ifadeyle, riskli yapı maliklerine ait payın idarece satışının gerçekleştirilebilmesi, öncelikle pay satışına ilişkin mevzuatta gösterilen şartların varlığına bağlıdır. İdare, pay satışına ilişkin şartların var olmadığına karar verirse istemi reddedecek; şartları taşıyan başvuruları ise kabul ederek, pay satışına ilişkin usul doğrultusunda satış işlemini gerçekleştirecektir. İhtiva ettiği bu önem dolayısıyla aşağıda pay satışının şartları üzerinde durulacaktır.

\section{A. RISKLI YAPI KARARININ VARLIĞI}

Riskli yapı, 6306 sayılı Kanun md.2 f.1/d uyarınca "riskli alan içinde veya dışında olup ekonomik ömrünü tamamlamış olan ya da yıkılma veya ağır hasar görme riski taşıdığı ilmî ve teknik verilere dayanılarak tespit edilen yapi” olarak tanımlanmaktadır ${ }^{30}$.

28 Bu yönde $\boldsymbol{b} k z$ Özmen / Ayar (n 25) 145 vd.: "Değer, rayiç (sürüm) değeridir. Bir bağımsız bölümün kat mülkiyetine geçiş sirasında değeri alım-satım değeridir. Ekonomik verilere göre arz ve talebin buluştuğu anda oluşan bu değer objektif kriterlerin irdelenmesi sonucu oluşur; yoksa sübjektif nedenlerle oluşan bedelin dikkate alınmayacağı açıktır. Sürüm veya rayiç değer olarak ifade edilen bu değerin oluşumunda piyasa kuralları göz önüne alınır ve bu değerin zamanla farkllaşması mümkündür.". Mahir Ersin Germeç, Kat Mülkiyeti Hukuku, (10. Bası, Seçkin Yayıncılık 2021) 80 vd.: "[...] arsa üzerindeki anayapının bağımsız bölümlerine arsa payı özgülenirken her bir bağımsız bölümün yüzölçümü, biçimi, kaçıncı katta bulunduğu, cadde veya sokağa cepheli olup olmadığı, güneşten yararlanma olanağı gibi unsurlar dikkate alınacaktır." Nitekim KMK md.3 f.2'de de "Kat mülkiyeti ve kat irtifakl, bu mülkiyete konu olan ana gayrimenkulün bağımsız bölümlerinden her birinin konum ve büyüklüklerine göre hesaplanan değerleri ile oranl olarak projesinde tahsis edilen arsa payını ortak mülkiyet esaslarına göre açıkça gösterilmesi suretiyle kurulur [...]" denerek kat mülkiyeti / irtifakı projesinde arsa payının bağımsız bölümlerin konum ve büyüklüğüne göre belirleneceği belirtilmiştir.

29 Yargıtay da kararlarında bu hususu arsa payının belirlenmesinde bağımsız bölümlerin cinsi, bulunduğu katı, alanı, ısınma sistemi, aydınlanması, mimari kullanımı ve konumu, cephesi ve manzarası, kullanma amacı [konut, işyeri vs.], eklentileri, güneşten yararlanma, rüzgâr ve diğer dış etkenlerden etkilenme olayı gibi hususlar dikkate alınır demek suretiyle belirtmektedir. Bu yönde $\boldsymbol{b} \boldsymbol{k} \boldsymbol{z}$ Yargitay 20 HD, E 2017/2569 K 2017/6174 04.07.2017; Yargitay 18 HD, E 2018/10404 K 2009/700, 05.02.2009.

30 Danıştay 6 D, E 1992/2066 K 1993/913, 08.03 .1993 çerçevesinde riskli yapı "ancak esasl bir onarımla tehlike arz etmeyecek duruma gelebileceği aksi takdirdeyıkılma tehlikesine altında olduğu anlaşılan yapı" olarak tanımlanmıştır. Kararda Danıştay, taşıyıcı unsurların bakımsızlıktan çürümesini, duvarlarda çatlakların olmasını ve duvar içindeki harcın bağlayıcı özelliğini kaybetmesini yapının yıkılacak dereceye getiren somut emareler olarak kabul etmektedir. (Bundan sonra Danıştay ve Bölge İdare Mahkemesi kararları için ayrıca bir kaynak belirtilmeyen hallerde, kararların 'Lexpera' bilgi bankasından alındığı kabul edilecek ve ayrıca kaynak gösterilmeyecektir). 
Şu hâlde, 6306 sayılı Kanun kapsamında pay satışı işleminin gerçekleşebilmesi için öncelikle ortada bir yapı olması gerekmektedir. 3194 sayılı İmar Kanunu'nun [“İK”] 5. maddesine göre yapı, "karada ve suda, daimî veya muvakkat, resmi ve hususi yeraltı ve yerüstü inşaatı ile bunların ilave, değişiklik ve tamirlerini içine alan sabit ve müteharrik tesislerdir”. Görüldüğü üzere İK, yapıı1 oldukça geniş tanımlamaktadır ${ }^{31}$. Ancak Uygulama Yönetmeliği, İK’ya göre yapı tanımı içerisinde değerlendirilebilecek her imalatı riskli yapı kararına konu olabilecek şekilde düzenlememiş; riskli yapı kararına konu olabilecek yapıların kapsamını daraltmıştır. Buna göre, “( r)iskli yapı tespiti; kendi başına kullanılabilen, üstü örtülü ve insanların içine girebilecekleri ve insanların oturma, çalışma, eğlenme veya dinlenmelerine veya ibadet etmelerine yarayan yapilar ile hayvanların ve eşyaların korunmasına yarayan yapılar hakkında yapılır. Inşaat halinde olup ikamet edilmeyen yapılar ile metrukluk veya başka bir sebeple statik bakımdan yapı bütünlüğü bozulmuş olan yapılar riskli yapı tespitine konu edilmez”. [Uygulama Yönetmeliği, md.7 f.1] Uygulama Yönetmeliği’nin bu hükmünden hareketle, 6306 sayılı Kanun ve alt mevzuatı kapsamında dönüşüme tabi tutulabilecek yapılardan, aslında İK’nın 5. maddesinde tanımlanan 'bina’ların ${ }^{32}$ anlaşılması gerektiği söylenebilecektir ${ }^{33} 34$.

Uygulama Yönetmeliği ayrıca, 'inşaat halinde olmama ve ikamete elverişli olma' ile 'statik bakımdan yapı bütünlüğ̈̈ bozulmamış olma' şeklinde iki ek koşul öngörmek suretiyle, dönüşüme tabi olabilecek binaların kapsamını biraz daha daraltmıştır. Buna karşın, dönüşüme tabi olabilecek bina niteliğindeki yapılar hakkında, ruhsatlı-ruhsatsız, yapı kullanma izni olan-olmayan şeklinde ayrımlara gidilmeyerek ${ }^{35}$, 6306 sayılı Kanun'un amacına paralel şekilde kapsam bu yönden geniş tutulmuştur.

Şüphesiz bu nitelikte bir binanın varlığı, tek başına, uygulama işlemlerine konu edilmesine imkân tanımayacaktır. Bunun için anılan nitelikteki binanın fenni bakımdan 'riskli' nitelik taşıması ve bu yönde bir risk tespiti yapılması gerekmektedir ${ }^{36}$. Taşınmazın hukuki statüsünü değiştiren bu

31 'Yapı' kavramı hakkında ayrıntılı bilgi için $\boldsymbol{b k z}$ Hasan Nuri Yaşar, Imar Hukuku (1. Bası, Filiz Kitabevi 2008) 229 vd.; Taner Ayanoğlu, Yapı Hukukunun Genel Esasları (1. Bası, Vedat Kitapçılık 2014) 6 vd.; Ömer Koroğlu, Imar Hukukunda Yapı Kavramı ve Temel Yapı Belgeleri (1. Bası, On İki Levha Yayıncılık 2017) 11 vd.

32 İK md.5: "Bina; kendi başına kullanılabilen, üstü örtülü ve insanların içine girebilecekleri ve insanların oturma, çalışma, eğlenme veya dinlenmelerine veya ibadet etmelerine yarayan, hayvanların ve eşyaların korunmasına yarayan yapılardır”.

33 Bu nedenle çalışmanın bundan sonraki kısmında imar mevzuatı ve 6306 Sayılı Kanun arasında kavramsal bütünlüğü sağlamak adına, riskli yapı kararına konu edilmiş yapı için mümkün olduğunca 'bina' kavramı tercih edilecektir.

34 Nitekim 6306 sayılı Kanun’un 6. maddesinde “[...] (ü)zerindeki bina yıkılarak arsa hâline gelen taşınmazlarda(n) [...]” bahsederken; Uygulama Yönetmeliği’nde de riskli yapı tespit raporuna konu edilen binanın Ulusal Adres Veri Tabanında belirtilen adresinin ve bina kodunun yer alması zorunluluğu hüküm altına alınmıştır (md.7/3).

35 Aynı yönde $\boldsymbol{b} \boldsymbol{k z}$ Üstün, Kentsel Dönüşüm Hukuku (1. Bası, On İki Levha Yayıncılık 2014) (n 3) 131 . “634 sayılı Kat Mülkiyeti Kanunu uyarınca kat irtifakı veya kat mülkiyeti kurulmadığ i ç̧in arsa payl tapu var ise, arsa üzerinde fiilen bulunan yapının riskli yapı tespiti, yapının sahibi olan arsa payı sahibince; arsa üzerindeki yapının başkasına ait olması ve bunun da tapu kütüğ̈̈nde belirtilmiş olması halinde, riskli yapı tespiti lehine şerh olan tarafça yaptırılacaktır."

36 Riskli yapı tespiti hakkında bkz Gürsel (n 5) 146 vd.; Gün Yazıcı, Yargı Kararları Işı̆̆ında Kentsel Dönüşüm, Riskli Yapılar ve Yargısal Denetim (1. Bası, Seçkin Kitabevi 2018) 34 vd.; Hakan Karadabağ, Mülkiyet Hakkı Çerçevesinde Kentsel Dönüşüm (1. Bası, Legal Yayıncılık 2020) 76 vd.; Üstün, Kentsel Dönüşüm Hukuku (1. Bası, On İki Levha Yayıncılık 2014) (n 3) 131. 
tespit, 6306 sayılı Kanun kapsamında kentsel dönüşüm sürecinin de başlangıc1 ${ }^{37}$ ve pay satışının ilk şartıdır $^{38}$. Bu karardan sonra taşınmaz, 6306 sayılı Kanun'un hukuki rejimine tabi olacaktır ${ }^{39}$.

Riskli yapı tespit kararı, idari davaya konu edilebilen, kesin ve yürütülebilir nitelikte bir idari işlemdir. 6306 sayılı Kanun ${ }^{40}$ ve Uygulama Yönetmeliği’nde ${ }^{41}$ öngörülen itiraz yolu, ihtiyari nitelikte olup; yapılacak itiraz, İdari Yargılama Usulü Kanunu'nun [“IYYUK”] 11.maddesi kapsamında gerçekleştirilen bir başvurudur.

Malikler veya kanuni temsilcilerince bu yola başvurulmaksızın idari yargıda dava açılmasının önünde herhangi bir engel bulunmamaktadır. Şu hâlde, itiraz yolu için öngörülen süre geçmeden veya bu yola başvurulmuşsa sonucu beklenilmeden kararın hüküm ve sonuçlarını doğurmadığını söylemek mümkün değildir. Riskli yapı tespit kararının varlığı, maliklerce veya kanuni temsilcilerince itiraz yoluna gidilmesinden bağımsız olarak, yapının hukuki statüsünü değiştirmekte; böylece pay satışının ilk şartı gerçekleşmektedir. Uygulama Yönetmeliği’nin 8/1.maddesinde yer alan, “( $r$ iskli yapı tespitine karşı yapılan itirazın reddedilmesi veya riskli yapı tespitine itiraz edilmemesi suretiyle, riskli yapı tespitinin kesinleşmesi halinde Müdürlük, gerekli tebligatların yapılmasını ve riskli yapının yıktırılmasını İdareden ister” şeklindeki hüküm ise yapının yıktırılması için ön görülmüş bir şart olup; idari işlemin [riskli yapı tespiti kararı] niteliğinde bir değişiklik yaratmamaktadır.

\section{B. MALIKLERIN ANLAŞMASI VE PAY SATIŞI KARARININ ALINMASI}

Riskli yapı tespit kararının alınmasından sonra maliklerin taşınmazda gerçekleştirilecek uygulama işlemleri konusunda bir karar alması gerekmektedir. Maliklerin riskli yapı kararına konu taşınmazda gerçekleştirilecek uygulama işlemleri konusunda oy birliği ile karar almaları durumunda paydaşlar arasında bir hukuki ihtilaf doğmayacağı açıktır. Bu anlamda hukuki problem, maliklerin riskli yapı olarak tespit edilmiş taşınmazda ne yönde tasarruf edeceklerine ilişkin tam bir mutabakata varamaması halinde ortaya çıkar.

37 Riskli yapı tespitinin, pay satışının dayanağı olduğu yönünde $\boldsymbol{b} \boldsymbol{k} z$ İstanbul BİM 4 İDD, E 2017/1173 K 2017/1346, 29.12.2017.

38 Tespiti yapmaya yetkili idareler [Yönetmelik md.6, md.7 / Kanun md.3]; tespit talebinde kimlerin bulunabileceği [Yönetmelik md.7 / Kanun md.3] ve usulü [Yönetmelik md.7 / Kanun md.8] ile tespite yapılacak itirazlara [Yönetmelik md.7 / Kanun md.3, md.8] ilişkin hükümler, 6306 sayılı Kanun ve Uygulama Yönetmeliğinde belirlenmiştir.

39 Bu hukuki rejime tabi olmanın beraberinde getirdiği sonuçlardan birisi de, doğacak uyuşmazlıkların idari yargıda çözümlenmesi gerekeceğidir. "[...] (D)avaya konu satış işlemine dayanak olarak gösterilen 26.06.2014 tarihli, 12 nolu kat malikleri kurulu kararı veya 03.07.2015 tarihli arsa payı hak sahipleri ortak kararı, 6306 sayıl Kanun'un 6. maddesi ve 6306 sayıl Kanun Uygulama Yönetmeliğinin 15. ve 15/A. maddeleri hükümleri uyarınca alınmış kararlar olup bu kararların hukuki denetiminin İdari Yargı mercilerince 6306 sayıl Kanun hükümlerine göre yapılması gerektiğinden [...]”, Danıştay 14 D, E 2016/8636 K 2017/1089, 28.02.2017.

406306 sayılı Kanun md. 6/1: “[...] Bakanlıkça veya İdarece yaptırılan riskli yapı tespitlerine karşı maliklerce veya kanuni temsilcilerince on beş gün içinde itiraz edilebilir. Bu itirazlar, Bakanlığın talebi üzerine üniversitelerce, ilgili meslek disiplini öğretim üyeleri arasından görevlendirilecek dört ve Bakanlıkça, Bakanlıkta görevli üç kişinin iştiraki ile teşkil edilen teknik heyetler tarafindan incelenip karara bağlanır."

416306 sayılı Kanun md. 7/6: “Riskli yapı tespitine karşı yapı malikleri veya kanunî temsilcilerince on beş gün içinde yapının bulunduğu yerdeki Müdürlüğe veya Bakanlıkça yetki devri yapılması durumunda İdareye verilecek bir dilekçe ile itiraz edilebilir." 
Kanun'un "uygulama işlemleri” başlıklı 6. maddesine göre, " [...] riskli yapılarda [...] bu yapıların bulunduğu parsellerde, yapılar yıktırlmadan önce, parsellerin tevhit edilmesine, münferit veya birleştirilerek veya imar adası bazında uygulama yapılmasına, ifraz, terk, ihdas ve tapuya tescil işlemlerine, yeniden bina yaptırılmasına, payların satışına, kat karşıllğ̆ veya hasılat paylaşımı ve diğer usuller ile yeniden değerlendirilmesine, yapının paydaşı olup olmadıkları gözetilmeksizin sahip oldukları hisseleri oranında paydaşların en az üçte iki çoğunluğu ile karar verilir".

Görüldüğü üzere, mevzuatta riskli yapı kararına konu binanın bulunduğu parselin ne şekilde değerlendirileceği hususu numerus clausus değildir ${ }^{42}$. Malikler, riskli yapı tespiti kararı üzerine, taşınmazda gerçekleştirilecek imar uygulamaları ve taşınmazın ne şekilde değerlendirileceğine ilişkin kararlar almaktadırlar. Maliklerin alacakları bu karar(lar), paydaşların muhalif kalmalarına, pay satış kararı alınmasına, sonrasında satışa konu edilecek payların değerine ve mülkiyet hakkına doğrudan etki edecek niteliktedir. Nitekim Anayasa Mahkemesi, bireysel başvuru yoluyla önüne gelen bir uyuşmazlıkta, riskli yapı tespiti kararı sonrası malikler aldığ kamuya bedelsiz terk ${ }^{43}$ kararı neticesinde gerçekleşen terk işlemi bakımından, uygulama işlemleri içerisinde 'terk'in düzenlenmediği ${ }^{44}$, terk miktarına ${ }^{45}$ ilişkin hüküm bulunmadığı ve muhalif paydaşların payının yola

42 Madde metninde geçen "[...] diğer usuller ile yeniden değerlendirilmesine [...]" ifadesinin, en az 2/3 çoğunlukla karar alan maliklerin sınırsız bir takdir yetkisine sahip oldukları anlamına gelmediği; bu ifadenin - "yıkılacak taşınmazın arsasının tüm maliklere (azınlı̆a da) ekonomik olarak makul ve yüksek yarar sağlayacağı bir değerlendirme" olarak dar yorumlanması gerektiği ifade edilmektedir. Malikler tarafından bu nitelikte bir karar alınmamışsa, 6306 sayılı Kanun’un 6.maddesi kapsamında alınmıs bir kararın bulunmadığının kabul edilmesi gerektiği hususunda $\boldsymbol{b} \boldsymbol{k} z$ Turgut Öz, 'Kentsel Dönüşüm Kanunu Çerçevesinde Yapı Maliklerinin Üçte İki Çoğunlukla Alacakları Kararın İçeriğinin Amaca Göre Sınırlanabilmesi’ İstanbul Kültür Üniversitesi Hukuk Fakültesi Dergisi (2016) 15(1) 391, 396-399.

43 Bir imar hukuku kurumu olan bedelsiz terk, "malikin parselinde yapılaşmaya gidebilmesi için imar planında yol veya kamu hizmetleri için gösterilmiş kısmını terk etmesidir", Oğuz Sancakdar, İmar Hukuku (1. Bası, SBNET Uzaktan Eğitim ve Yayıncllık 2020) 299-300; "İmar hukuku bakımından bedelsiz terk genel olarak bir taşınmazın tamamının veya bir bölümünün, belli şartlar gerçekleştiğinde, yasada sayılan kamu hizmetlerinin yerine getirilmesinde ihtiyaç duyulan taşınmazların sağlanması amacıyla sahibine herhangi bir bedel ödenmeden yetkili ve görevli idare lehine mülkiyetinin terk edilmesini, dolayısılyla anılan taşınmazın mülkiyetinin idareye geçirilmesini ifade eder", Ramazan Yıldırım, 'İdareye Taşınmaz Mal Kazandıran Bedelsiz Terk, Devir ve Temlikler' KTO Karatay Üniversitesi Hukuk Fakültesi Dergisi (2016) $1(2)$ 13,14. Şu hâlde terk, riskli yapının bulunduğu parselde var olan imar rejimi kapsamında yapılaşmaya gidilebilmesi için gerçekleştirilmesi zorunlu bir uygulama olarak karşımıza çıkabilmektedir.

Kişi yapı yapmak istemediği müddetçe terkin gündeme gelmeyeceği; yapı yapılmak istenmesi halinde ise, terk talebinin her parsel için olmayabileceği, olması halinde ise DOP’tan farklı olarak aynı oranda istenilmeyebileceği hususunda $\boldsymbol{b} \boldsymbol{k} \boldsymbol{z}$ Sancakdar (n 43) 300.

44 Türk Silâhlı Kuvvetleri Personel Kanunu ile Bazı Kanunlarda Değişiklik Yapılmasına Dair Kanun ["7281 sayılı Kanun”], Kanun Numarası: 7281, Kabul Tarihi: 18/2/2021, RG 05.03.2021/31414, 7281 sayılı Kanun'la 6.maddede yapilan değişiklikle, maddeye "terk" ibaresi eklenmiştir. Ancak, riskli yapıda en az 2/3 çoğunlukla alınacak 'terk' kararına ilişkin, Yüksek Mahkemenin aradığı üst sınır 6306 sayılı Kanun'da bulunmamaktadır.

45 Terke ilişkin üst sınır belirlenmesinin, imar hukukunun arazi esaslı olması, arazinin her yerde aynı nitelikte olmaması, farklı imar planlarına dayalı farklı yapılaşma koşullarının varlığı gibi sebeplerle ne denli mümkün ve isabetli olacağı üzerinde ayrıca düşünülmelidir.

Öte yandan, terk işlemi neticesinde taşınmazın yüzölçümünde azalma olmaktaysa da değerinde bir artı̧ olacağ 1 kuşkusuzdur. Anayasa Mahkemesi kararında, bu değer artışı ile terk nedeniyle katlanılan külfetin, terke ilişkin üst sınır belirlenmemiş olması nedeniyle ölçülemediğinden bahsedilmektedir. Ancak, üst sınırın belirlendiği DOP’ta da bu ölçümün tam olarak gerçekleştirilemediğini ifade etmek gerekmektedir. Şu hâlde, nimet-külfet dengesine ilişkin bu değerlendirmenin, üst sınırın belirlenmesiyle doğrudan ilgili olmadığını söylemek yanlış olmayacaktır. Ayrıca terk işleminin, imar rejimine aykırılık taşıması veya taşınmazın yüzölçümünde gerçekleşecek azalma ile değerinde gerçekleşecek artış arasında, payı satışa konu edilecek maliklerin mülkiyet haklarına ölçüsüz müdahale teşkil edecek 
terk kararı sonrasında taşınmazın yüzölçümünde gerçekleşen küçülme neticesi satılması sebebiyle, mülkiyet hakkının ihlal edildiği sonucuna ulaşmıştır ${ }^{46}$.

Riskli yapı tespiti kararı sonrasında maliklerin, karara konu taşınmazın değerlendirilmesi konusunda alacakları kararlar içinse, 6306 sayılı Kanun ve Uygulama Yönetmeliğinde, kararın zamanı ve nisabı ile alınma usulüne ilişkin özel hükümler getirilmiştir. Kanun koyucu, maliklerin taşınmazın ne şekilde değerlendirileceği hususunda anlaşamayarak, aralarında hukuki ihtilafın doğması ihtimaline binaen riskli yapı olarak tespit edilmiş binada gerçekleştirilecek uygulama işlemleri konusunda karar almaya ilişkin genel hükümlerden ayrı bir nisap ve usul öngörmüştür. Bu karara katılmayanların sahip oldukları payların ise satılmasına imkân tanımıştır. Bu olanak, kentsel dönüşüm rejiminin kamusal yönünün tezahürüdür ${ }^{47}$. Kişilerin [riskli yapı maliklerinin] mülkiyet hakkını doğrudan etkileyen - hatta sonlandıran - bu hukuki imkânın hukuka uygun şekilde kullanılabilmesi için karar nisabı ile kararın alınma zamanı ve usulü üzerinde ayrıca durulması gerekmektedir.

\section{KARAR NISABI}

Riskli yapıda gerçekleştirilecek uygulama işlemleri konusunda riskli yapı maliklerinin oy birliği ile mutabakat sağlayamamaları halinde kanun koyucu, afet riski altındaki binanın fen ve sanat norm ve standartlarına uygun şekilde dönüşümünü sağlayabilme adına, paydaşların en az 2/3 çoğunluğuyla alınan kararı yeterli bulmaktadır. Bu durumda, karara katılmayan maliklerin paylarının akıbeti sorunu gündeme gelmekte; 6306 sayılı Kanun'da bu payların satışına imkân tanımaktadır. 6306 sayılı Kanun’un 6. maddesine göre, "[...] riskli yapılarda ise bu yapıları bulunduğu parsellerde, yapılar

nitelikte olması halinde, terk işlemine karşı yargı yoluna gidilebileceğine kuşku yoktur. Bu nedenle, 6306 sayılı Kanun'un 6.maddesinin açık hükmüne karşın, üst sınır belirlenmemesi nedeniyle en az 2/3 nisapla terke ilişkin karar alınamayacağını söylemek mümkün gözükmemektedir.

$\mathrm{Bu}$ noktada üzerinde durulması gereken bir husus ise, en az 2/3 nisapla alınan terk veya diğer uygulama işlemlerine (tevhit, ifraz gibi) ilişkin kararının ne zaman icra edileceğidir. Bu sorunun cevabını, yukarıda yer verilen Anayasa Mahkemesi kararına konu olan terk işlemi üzerinden vermek mümkündür. Terke ilişkin kararın en az 2/3 çoğunlukla alınmasını müteakip, terk işleminin satıştan sonraya bırakılmasının, muhalif paydaşın elde edeceği bedele (mülkiyet hakkına) olumlu etki edeceği düşünülebilecektir. Gerçekten de terk kararının alınmasından sonra ve/fakat işlemler tamamlanmadan pay satışının gerçekleştirilmesi halinde, taşınmazın yüzölçümü küçülmeksizin pay satışa çıkarılacaktır. Ancak satışa katılacak malikler ve üçüncü kişiler, terkin gerçekleştirileceğini maliklerce alınan karardan bilmektedirler. Hatta üçüncü kişilerin satışa katılabilmeleri için, "satıştan önce üçte iki çoğunluk ile alınan kararı kabul edeceklerini ve üçte iki çoğunluk ile alınan karar doğrultusunda yapılan sözleşmeyi ve yapılacak uygulamanin gerektirdiği diğer belgeleri imzalayacaklarım yazılı olarak beyan etmeleri" gerekmektedir. Bu durumun, imar durumu belirsiz bir taşınmaza ait payın satı̧ına katılacakların tekliflerine olumsuz etki edeceğini öngörmek hiç de zor değildir. Öte yandan, terk işlemlerinin pay satışından sonraya bırakılmasında ortaya çıkacak bir başka sorun da satışa konu edilecek payın rayiç bedel tespitinde ortaya çıkacaktır. Terke ilişkin alınan karar doğrultusunda, terkin gerçekleşmesi, satışa konu edilecek payın rayiç bedelinin doğru tespit edilmesine direkt etki edecektir. Tüm bu açıklamalardan anlaşıldığı üzere, en az $2 / 3$ çoğunlukla, 6306 sayılı Kanun’un 6.maddesi uyarınca, pay satışı yanında terke - ya da diğer imar uygulamalarına - ilişkin de karar alınması halinde, muhalif paydaşların satışa konu edilecek paylarının rayiç bedelinin doğru tespiti ve satışın rekabet koşulları altında gerçekleştirilebilmesi için, işlemlerin tamamlanarak payın satışa çıkarılması isabetli olacaktır.

Anayasa Mahkemesi 1 B, B 2018/1406, 30.06.2021.

47 Emrah Kulaklı, 'Türkiye’de Kentsel Dönüşüm Rejimini Ortaya Çıkaran Nedenler, Uygulaması ve Özel Hukuk Alanına Bazı Etkileri' in Furkan Beşel, Fatih Yardımcıoğlu ve Hakkı Bağcı (eds), Uluslararası Politik, Ekonomik ve Sosyal Araștırmalar Kongresi ICPESS 2017 Bildiri Özetleri Kitabı (Kaşköprü Yayınları 2017) 289. 
yıktırılmadan önce, [...] payların satışına, [...] yapının paydaşı olup olmadıkları gözetilmeksizin sahip oldukları hisseleri oranında paydaşlarm en az üçte iki çoğunluğu ile karar verilir. Bu karara katılmayanların arsa payları, Bakanlıķ̧a rayiç değeri tespit ettirilerek ve bu değerden az olmamak üzere anlaşma sağlayan diğer paydaşlara açık artırma usulü ile satılır". Şu hâlde, riskli yapılarda gerçekleştirilecek uygulama işlemleri konusunda, paydaşların en az 2/3'ü ile karar verilmesi durumunda, karara katılan maliklerce karara katılmayan maliklerin paylarının satışı yönünde de bir karar tesisi gerekmektedir.

Bu noktada üzerinde durulması gereken husus ise üçte iki çoğunluğun ne şekilde belirleneceğidir. 6306 sayılı Kanun'da bu hesap yapılırken "yapının paydașı olup olmadıkları gözetilmeksizin sahip oldukları hisseleri oranında paydaşların en az üçte iki çoğunluğu ile karar verilir” hükmü yer almaktadır. Anılan hükümdeki nisabın, pay ve paydaş çoğunluğunu mu yoksa yalnızca pay çoğunluğunu mu kastettiği doktrinde tartışılmış; bu nisabın pay çoğunluğu olduğu görüşü kabul edilmiştir ${ }^{48}$. Gerçekten de kanun koyucu bu hususta, TMK’nın paylı mülkiyet veya KMK’nın kat mülkiyetinde maliklerin taşınmazda tasarrufta bulunmalarına ilişkin öngörülen karar nisabından farklı bir kural belirlemiştir. Kanun, 2/3 nisaba ilişkin olarak, yalnızca 'pay'ı (hisseyi) ${ }^{49}$ esas almıştır ${ }^{50} .6306$ sayılı Kanun'un amacı gözetildiğinde, riskli olduğunun tespit edilmesi nedeniyle - güçlendirmeye konu edilemeyecekse yıkılacak bir bina hakkında pay satı̧ıına karar verilmesinde 'pay (hisse)'ın esas alınmasının isabetli bir yaklaşım olduğu söylenebilecektir.

Burada dikkat çekilmesi gereken bir diğer ifade ise 2/3 nisabının "yapının paydaşı olup olmadıkları gözetilmeksizin” maliklerin hisseleri oranında hesaplanacağının düzenlenmiş olmasıdır ${ }^{51} . \mathrm{Bu}$ ifadeden hareketle, yapının paydaşı olmadan hisse sahibi olan paydaşın söz konusu olup olmayacağı sorusu akla gelmektedir. Bu ifadenin, uygulama işlemlerine [dolayısıyla pay satışına] yönelik alınacak kararlarda, paydaş sayısının hesaba katılmayacağına, yalnızca hissenin esas alınacağına ve bina ile arzın mülkiyetinin farklılaşabildiği durumlarda, arsa malik(ler)inin hissesinin hesaba katılması gerektiğine işaret etmek üzere getirildiği söylenebilecektir ${ }^{52}$.

48 2/3 oranının yalnızca pay üzerinden hesaplanması gerektiği yönünde $\boldsymbol{b} \boldsymbol{k} z$ Üstün, Kentsel Dönüşüm Hukuku (1. Bası, On İki Levha Yayıncılık 2014) (n 3) 163; Şimşek (n 14) 149 vd.; Öz (n 42) 391-402; Özsunay (n 11) 32; Yazıc1 (n 36) 56; Gürsel (n 5) 191; Özmen / Şengül (n 26) 74 vd.

49 Pay ve hisse kavramları hakkında $\boldsymbol{b} \boldsymbol{k} \boldsymbol{z}$ "Satışın Konusu: Pay (Hisse)" başlı̆̆ı.

50 Kat mülkiyeti/kat irtifakı kurulu binalarda, yapı yıkılmadan önce bu kararın alınması söz konusu ise karar nisabı toplam arsa payı üzerinden hesaplanacaktır.

51 “Yapının paydaşı olup olmadıkları gözetilmeksizin” ibaresi, Uygulama Yönetmeliği’nin 15/2.maddesinde de yer alan almaktadır. Yönetmelik’te yer alan bu ibare iptal davasına konu edilmiş; ancak Danıştay bu ifadenin iptali istemini şu gerekçeyle reddetmiştir: "(A)fet riski altındaki yapıların iyileştirilmesi, tasfiyesi ve yenilenmesine ilişkin uygulamaların ivedilikle yapılmasının kamu yararına hizmet ettiği, fen ve sanat norm ve standartlarına uygun, sağlıkl ve güvenli yaşama çevrelerini teşkil etmek üzere afet riski altındaki alanlarda bulunan veya bu alanlar dışında olup da riskli olduğu tespit edilen yapıların yıkılarak yerine yenisinin yapılması sürecinde maliklerin haklarına zarar vermeden, ancak uygulamanın da sürüncemede kalmasına mahal vermeden iş ve işlemlerin yürütülmesinin hedeflendiği anlaşılmaktadır.

Bu durumda; kanun koyucu tarafindan idareye tanınan düzenleme yetkisi uyarınca dava konusu Yönetmelik hükümlerinin öngörüldüğ̈̈, normlar hiyerarşisine, dayană̆ Kanun maddelerine ve sağlikl bir çevrede yaşama hakkı ilkesine uygun olarak, kamu yararı ve hizmet gerekleri doğrultusunda düzenleme yapıldı̆̆ı sonucuna ulaşıldığından, yukarıda belirtilen iptale konu Yönetmelik kuralında hukuka aykırılık bulunmamaktadır”, Danıştay 6 D, E 2019/15170 K 2020/11080, 18.11.2020.

52 Bu yönde bir karar için $\boldsymbol{b} \boldsymbol{k} z$ Danıştay 6 D, E 2019/15170 K 2020/11080, 18.11.2020. 
Gerçekten de 6306 sayılı Kanun'un uygulanmasını göstermek üzere çıkarılan Uygulama Yönetmeliği’ne bakıldığında bu çıkarımların hukuki dayanaklarını görmek mümkündür. Uygulama Yönetmeliği’nin 15/7.maddesine göre, "(b)ir parselde birden fazla yapı bulunması ve bu yapıların tamamının riskli yapı olarak tespit edilmiş olması halinde, yürütülecek uygulamalara yapının paydaşı olup olmadıkları gözetilmeksizin sahip oldukları hisseleri oranında bütün maliklerin en az üçte iki çoğunluğu ile karar verilir”. Görüldüğü üzere, bir parsel üzerinde birden fazla riskli yapının varlığı halinde ${ }^{53}, 2 / 3$ nisabı her bir riskli yapı için ayrı ayrı aranmamakta; riskli yapıların maliklerinin ${ }^{54}$ sahip oldukları toplam hisse üzerinden bu nisap hesaplanmaktadır. Ayrıca, Uygulama Yönetmeliği’nin "Riskli yapıların tespiti ve itiraz" başlıklı 7/2.maddesinde, "(a)rsa üzerindeki yapının başkasına ait olması ve bunun da tapu kütüğ̈̈nde belirtilmiş olması halinde, riskli yapı tespiti lehine şerh olan tarafça yaptırılır" hükmüne yer verilerek, yapı maliki ile arsa malikinin farklılaşabileceğine işaret edilmiştir. Böyle bir durumda, riskli yapı tespiti için başvurabilecek olan kişi(ler) ile uygulama işlemlerine karar verecek kişi(ler) ayrılmakta; riskli yapı tespiti gerçekleştirildiği takdirde, taşınmazda ne yönde tasarruf edileceğine (ve pay satışına), yapının maliki olup olmadığına bakılmaksızın, arsa maliklerinin payları doğrultusunda karar verilecektir 55 .

Şu hâlde, uygulama işlemlerine [ve pay satışına] ilişkin alınacak kararlarda aranan 2/3 nisabın, parsel üzerinde bulunan riskli yapı/yapıların maliklerinin arsa üzerinde sahip oldukları hisseler üzerinden hesaplanacağını söylemek mümkündür.

\section{KARARIN ALINMA ZAMANI}

6306 sayılı Kanun'un 6/1.maddesine göre, “[...] riskli yapılarda [...] bu yapıların bulunduğu parsellerde, yapılar yıktırılmadan önce, [...] payların satışına, [...] yapının paydaşı olup olmadıkları gözetilmeksizin sahip oldukları hisseleri oranında paydaşların en az üçte iki çoğunluğu ile karar verilir”. Buna göre kanun koyucu, pay satışına ilişkin alınacak kararın - riskli yapı hakkında alınabilecek diğer kararlar gibi - riskli yapı tespiti kararından sonra ve/fakat yapı yıktırılmadan önce alınacağını hüküm altına almıştır.

Peki, yapı yıkıldıktan sonra malikler, pay satışına veya riski yapıda ne yönde tasarrufa girişileceğine ilişkin bir karar tesis edemeyecekler midir? Kanun'un lafzına bakılarak pay satışına ilişkin kararın mutlaka yapı yıktırılmadan önce alınabileceği gibi anlam çıkarılması mümkünse de mezkûr maddeye

53 Bu durum, - toplu yapılarda olduğu gibi - yapıların ilk inşa aşamasından itibaren söz konusu olabileceği gibi; yapılaşması tamamlanmış alanlarda idarece, tek taraflı olarak, İK’nın 18. maddesi uyarınca gerçekleştirilecek bir imar uygulaması (arazi ve arsa düzenlemesi) sonucunda veya tevhid işlemi neticesinde de ortaya çıkabilecektir. İK’nın yanı sıra, 6306 sayılı Kanun'un 6/5.maddesinde bu işlemlere ilişkin olarak Çevre ve Şehircilik Bakanlı̆̆ı’na geniş yetkiler verilmiştir.

54 Ayrıca bkz Uygulama Yönetmeliği, md.15/8: "Bir parselde birden fazla yapı bulunmast ve bu yapılardan bazılarının riskli yapı olarak tespit edilmiş olması halinde;

b) Yürütülecek uygulamalara sahip oldukları hisseleri oranında riskli olarak tespit edilen yapıların maliklerinin en az üçte iki çoğunluğu ile karar verilir".

55 İstanbul BİM 4 D, E 2017/474 K 2017/293, 24.04.2017:“[...] (B)inada ortak olup olmadiklarina bakılmaksizin arsanin üçte iki çoğunluk hissesine sahip maliklerce alınacak karar ile pay satışının mümkün olduğu hususunda tartışma bulunmamaktadir". 
6704 sayılı Kanun'la eklenen ${ }^{56}$ “[... y yapılar yıktırılmadan önce [...]” ifadesinin ihdas edilme nedenine yakından bakıldığında ${ }^{57}$, kanun koyucunun iradesinin bu yönde olmadığı anlaşılacaktır ${ }^{58}$. Gerçekten de malikleri, riskli yapı tespiti kararı verilmesi ile binanın yıkımı arasındaki kısa sayılabilecek bir sürede anlaşmak zorunda bırakmaya; yıkımdan önce en az 2/3 nisapla anlaşma sağlanamaması halinde ise 6306 sayılı Kanun'un kapsamı dışına çıkarmaya olanak bulunmamaktadır.

Bina hakkında 6306 sayılı Kanun kapsamında riskli yapı tespit kararı alınmasıyla birlikte, taşınmaz artık 6306 sayılı Kanun'un hukuki rejimine tabi olacaktır. Alınan riskli yapı tespit kararının kesinleşmesini müteakiben yapının yıkılacağ ${ }^{59}$ veya şartların varsa (Uygulama Yönetmeliği md.8/5) güçlendirilmek suretiyle afete dayanıklı hale getirileceği muhakkaktır. Bir binanın riskli yapı olarak tespiti ve buna bağlı olarak kamu düzeni açısından yarattığ 6306 sayılı Kanun'un amacına ne kadar uygunsa; riskli yapının yıkımı sonrasında, taşınmazın ve maliklerin 6306 sayılı Kanun kapsamında mütalaa edilemeyeceğinin söylenmesi de dönüşüm uygulamalarını zorlaştıracak olması nedeniyle 6306 sayılı Kanun'un amacına bir o kadar aykırıdır. Bu nedenle, maliklerin yapı yıktırılmadan önce veya sonra pay satışı veya diğer uygulama işlemleri yönünden karar almasının önünde herhangi bir engel bulunmadığının kabulü gerekmektedir. Kaldı ki, gerek 6306 sayılı Kanun'da ${ }^{60}$ gerekse de Uygulama Yönetmeliği'nde ${ }^{61}$, yapının yıkımı sonrasında da pay satışı veya dönüşüm uygulamalarına yönelik diğer kararların alınabileceğine ilişkin hükümler düzenlenmiştir. Şu hâlde, taşınmaz maliklerinin pay satışına ilişkin kararı, bina yıkılmadan önce veya sonra almalarının mümkün olduğuna kuşku yoktur.

566306 sayılı Kanun'un 6/1.maddesinin 6704 sayılı Kanun'la yapılan değişiklikten önceki hali şu şekildedir: “Üzerindeki bina yıkılarak arsa hâline gelen taşınmazlarda daha önce kurulmuş olan kat irtifakı veya kat mülkiyeti, ilgililerin muvafakatleri aranmaksızın Bakanlı̆̆ın talebi üzerine ilgili tapu müdürlügünce resen terkin edilerek, önceki vasfi ile değerlemede bulunularak veya malik ile yapılan anlaşmanın şartları tapu kütüğünde belirtilerek malikleri adına payları oranında tescil edilir. [...] Bu çerçevede, parsellerin tevhit edilmesine, münferit veya birleştirilerek veya imar adası bazında uygulama yapılmasına, yeniden bina yaptırılmasına, payların satışına, kat karşılığı veya hasılat paylaşımı ve diğer usuller ile yeniden değerlendirilmesine sahip oldukları hisseleri oranında paydaşların en az üçte iki çoğunluğu ile karar verilir”.

57 26.04.2016 tarihli Resmî Gazetede yayınlanan 6704 sayılı Kanun'un 23.maddesiyle, Kanun'un 6/1.maddesinde değişikliğe gidilmiş; yapılar yıktırılmadan önce uygulama işlemleri ve pay satışına ilişkin olarak kat malikleri kurulunca karar alınabilmesinin önü açılmıştır. Zira, bu değişiklikten önceki Yargıtay içtihadı, Kanun’un değişiklikten önceki lafzından hareketle, yapı yıkılmadan, kat mülkiyeti ve kat irtifakı müşterek mülkiyete dönüştürülmeden, 6306 sayılı Kanun’un uygulama alanı bulamayacağı yönündeydi. Bu yöndeki Yargıtay kararları ile eleştirisi hakkında bkz Bilgehan Çetiner, 'Kentsel Dönüşüme İlişkin Yargıtay 18. Hukuk Dairesinin 04.11.2015 Tarihli Kararına İlişkin İnceleme ve Değerlendirmeler' İstanbul Üniversitesi Hukuk Fakültesi Mecmuası (2016) 74(1) 233, 233-240.

58 Emrehan İnal, Kentsel Dönüşüm Hukukunda Riskli Yapı (1. Bası, On İki Levha Yayıncılık 2017) 94-95; Kürşad Yağc1, 'Kat Mülkiyetine Tabi Binaların Kentsel Dönüşüm Çerçevesinde Yıkılıp Yeniden Yaptırılmasında Aranacak Karar Nisabı' iç Tufan Ögüz ve Baki İlkay Engin (edr), Medeni Hukuk Alanındaki Güncel Yargıtay Kararlarının Değerlendirilmesi Sempozyumları Cilt 1 Eşya Hukuku (1. Bası, On İki Levha Yayıncılık 2016) 68.

59 Riskli yapının yıktırılması hususunda $\boldsymbol{b} \boldsymbol{k} \boldsymbol{z}$ "Riskli Yapının Yıkılması" başlığımız.

606306 sayılı Kanun md.6/2: “Üzerindeki bina yıkılmış olan arsanın maliklerine yapılan tebligatı takip eden otuz gün içinde en az üçte iki çoğunluk ile anlaşma sağlanamaması hâlinde, gerçek kişilerin veya özel hukuk tüzel kişilerinin mülkiyetindeki taşınmazlar için Bakanlık, TOKİ veya İdare tarafindan acele kamulaştırma yoluna da gidilebilir".

616306 sayılı Kanun md.15/5: "Kanunun 6’ncı maddesinin birinci fikrası uyarınca, üzerindeki riskli binanın yıkılmasından sonra arsa haline gelen taşınmazın satışına karar verilmesi halinde, bu satışın öncelikle Bakanlı̆̆a veya Bakanliğın uygun gördüğ̈̈ bağlı veya ilgili kuruluşuna veyahut da İdareye veya TOKİye teklif edilmesi gerekir". 
Ancak, üzerindeki binanın yıkılmış olmasına karşın, maliklerce taşınmazın ne şekilde değerlendirileceğine ilişkin en az 2/3 çoğunlukla karar alınmaması halinde, bu anlaşmanın gerçekleştirilmesini temin etmek için maliklere idarece tebligat yapılabilmektedir. $\mathrm{Bu}$ tebligat sonrasında otuz gün içerisinde maliklerce en az $2 / 3$ çoğunlukla karar alın(a)maması halinde taşınmaz, Bakanlık, TOKİ veya İdarece acele kamulaştırmaya konu edilebilecektir. (6306 Sayılı Kanun Madde 6/2 $)^{62}$.

$\mathrm{Bu}$ hükümden hareketle, bu statüde bulunan taşınmazlarda, maliklerce anlaşma sağlanmasının, tebligatı takip eden otuz günlük süreyle sınırlandırıldığı söylenebilecektir ${ }^{63}$. Ancak Danıştay bir kararında, bu hükmün ve otuz günlük sürenin, riskli alan ilan edilen bölge içerisinde kalan taşınmazlar için geçerli olduğunu işaret eder ifadelerde bulunmuştur. Buna göre: "Uyuşmazlikta, davalı idarece verilen bilgiler ıșığında, 6306 sayılı Kanunun 6. maddesinin birinci fikrasında uygulama işlemleri için paydaşların hisseleri oranında aranan en az üçte iki çoğunluk nisabının sağlandiğı beyan edildiğine göre "Üzerindeki bina yıkılmış olan arsanın maliklerine yapılan tebligatı takip eden otuz gün içinde en az üçte iki çoğunluk ile anlaşma sağlanamaması [...]" hâlinde hüküm ifade eden ve riskli alan içerisinde yer alan taşınmazların idarelerce acele kamulaştırllmasina imkan sağlayan aynı maddenin ikinci fikrası uygulama alanı bulamamakta, usulüne uygun olarak tebliğ edilerek, yeterli karar nisabinin alındiğ toplantıya ya da karara katılmadığı resmi belge ile kanitlanan kişilere ait hisselerden kaynaklanan uygulama problemlerinin birinci fikra uyarınca çözümlenmesi gerekmektedir"64. Görüldügü üzere Danıştay, 6306 sayılı Kanun’un 6/2.maddesinde yer alan hükmün, "riskli alan içerisinde yer alan taşınmazların idarelerce acele kamulaştırılmasına imkân sağlayan" bir düzenleme olduğunu ifade etmektedir. Bu ifadenin, anılan karara konu somut uyuşmazlığın riskli alanda bulunan taşınmazlara ilişkin olması sebebiyle mi, yoksa genel bir şart olarak değerlendirilmiş olması nedeniyle mi kullanıldığı, karardan tam olarak anlaşılamamaktadır.

Maliklerce alınacak kararın bina yıkılmadan önce veya yıkıldıktan sonra alınması, kamu düzenini ilgilendirmemekte; taşınmaz maliklerinin, mülkiyetten doğan haklarının kullanımını etkilemektedir. Üzerindeki bina, riskli yapı tespit kararı neticesinde yıkılarak arsa haline gelmiş bir taşınmazın, kamu düzenine herhangi bir olumsuz etkisi olmamasına karşın; malikleri otuz gün gibi kısa bir sürede anlaşmaya zorlamanın; sonrasında ise - özellikle riskli yapılar açısından - hiçbir "ivedilik"

62 Anayasa Mahkemesi, "[...] (A)fet riski altındaki yerleşim merkezlerinin iskân durumunun yeniden düzenlenmesinin bir parçası olarak malikleri tarafından kendi iradeleriyle değerlendirilmeyen taşınmazların, ilgili kamu kurum ve kuruluşları tarafindan kamulaştırma yoluyla değerlendirilmesinde kamu yararı bulunduğu açıktır [...]" șeklindeki soyut gerekçeyle bu hükmün Anayasa’ya aykırı olmadığına karar vermiştir, Anayasa Mahkemesi GK, E 2012/87 K 2014/41, 27.02.2014.

Anılan durumdaki taşınmazların acele kamulaştırmaya konu edildikten sonra, 2942 sayılı Kamulaştırma Kanunu’nun 3. Maddesi uyarınca bedellerin taksitle ödeneceğinin düzenlenmiş olmasının adil olmadığı hususunda ayrıca $\boldsymbol{b} \boldsymbol{k} z$ Gürsel Öngören, Kentsel Dönüşüm Hukuku (Öngören Hukuk Yayınları 2013) 39.

63 Ancak bu süre ve acele kamulaştırma yoluna başvurma, üzerindeki riskli yapı yıkılmış her taşınmaz için geçerli değildir. Burada idarenin takdir yetkisi bulunmaktadır. Nitekim maddede yer alan, "[...] acele kamulaştırma yoluna da gidilebilir" hükmü buna işaret etmektedir. İdare, üzerindeki riskli yapı yıkılmış olan taşınmazlar hakkında, kamulaştırma yoluna gitme/gitmeme; gidecekse, hangisi/hangileri için acele kamulaştırma yoluna başvuracağını belirleme ve başvurma zamanını tayin etme konusunda, kamu yararı ve kamu hizmetinin gerekleri doğrultusunda değerlendirme yapma yetkisine sahiptir. Zira, idarenin, maliklerin taşınmazda ne yönde tasarruf edileceği konusunda anlaşamaması nedeniyle, özel mülkiyette bulunun bir taşınmazı kamulaştırmak zorunda bırakılması, kamu yararı anlayışıly bağdaşmayacaktır. 
hali olmamasına rağmen, acele kamulaştırma yoluyla taşınmazlarını kamu mülkiyetine geçirmeye imkân tanımanın, mülkiyet hakkına ölçüsüz bir müdahale teşkil ettiğine kuşku yoktur. Zira burada artık, dönüşüm uygulamalarını ivedi şekilde gerçekleştirebilmek adına yapılan bir pay satışı değil, taşınmazın bütün olarak kamu mülkiyetine geçirilmesi söz konusudur.

Buna karşın, pay satışına ilişkin kararın, yapının yıkımından önce/sonra alınması, kararın alınmasına ilişkin usule etki edebilecek niteliktedir. Aşağıda bu husus üzerinde ayrıca durulacaktır.

\section{TOPLANTI USULÜ}

Riskli yapı tespiti kararının alınmasından sonra maliklerin taşınmazda ne şekilde tasarrufta bulunulacağına ilişkin karar almaları gerektiği daha önce ifade edilmişti. Bu kararın - ve pay satışı kararının - alınma usulü, sonuç işlem olan pay satışının hukuka uygunluğuna doğrudan etki etmesi sebebiyle büyük önem arz etmektedir. Bu kararın alınacağı toplantıya ilişkin olarak 6306 sayılı Kanun ve Uygulama Yönetmeliği’nde bir düzenleme yer almamaktadır. Uygulama Yönetmeliği’nin ilk halinde getirilmiş olan toplantı usulüne ilişkin kuralın, yıllar içerisinde birden fazla kere değişmiş olması nedeniyle konu daha da girift bir hal almıştır. Bu durum, kentsel dönüşüm uygulamalarında farklı toplantı usullerinin uygulanmasına yol açmaktadır. Uygulamadaki bu farklılık, yargı kararlarına da yansımakta; bu anlamda bir hukuki belirsizlik ortaya çıkmaktadır.

Nitekim İstanbul 7. İdare Mahkemesinin 31.05.2021 tarih, 2020/1762 E. ve 2021/823 K. sayll dosyasında ${ }^{65}$ pay satışına ilişkin idari işlemin iptaline karar verilmiştir. Yukarıda da ifade edildiği üzere, Uygulama Yönetmeliği’ndeki toplantı usulü müteaddit defalar değişikliğe uğramıştır. Nitekim 2014 yılında yapılan değişiklikle, maliklere noter yoluyla tebligat yapılması usulü kaldırılmış olmasına karşın, mezkûr kararda İdare Mahkemesi, değişiklikten önceki hükmü esas alarak, maliklerin - her ne kadar kararın içeriğinde zikretmese de - noter vasıtasıyla toplantıya çağrılmadığından bahisle pay satış işleminin iptaline karar vermiştir ${ }^{66}$.

Uygulama ve yargı kararlarında, kentsel dönüşüme yönelik toplantı usullerine ilişkin olarak bazı farklılıklara rastlanmaktadır. Bunun temel nedeni ise, toplantı usulüne ilişkin bir kuralın 6306 sayılı Kanun ve Uygulama Yönetmeliğìnde düzenlenmemiş olması ya da var olan düzenlemenin kaldırılmış olmasıdır.

Uygulama Yönetmeliğininin 15/2.maddesine göre, “(b)u karar anlaşma şartlarımı ihtiva eden teklif ile birlikte karara katılmayanlara noter vasıtasıyla veya 7201 sayıl Kanuna göre tebliğ edilir. Bu tebliğde, on beş gün içinde kararın ve teklifin kabul edilmemesi halinde arsa paylarının, [...] satılacağı bildirilir". Maliklerce riskli yapıda gerçekleştirilecek uygulama işlemlerine ilişkin alınan karara sonradan katılma

65 Karar yayınlanmamıştır.

66 Buna karşın İstanbul 14. İdare Mahkemesinin 2021/825 E. sayılı iptal davasında, mahkemenin 30.06 .2021 tarihli ara kararı [karar yayınlanmamıştır] ile bütün maliklerin noter aracılığıyla davet edilmediği bir kat malikleri kurulu akabinde alınan pay satışına ilişkin işlemin yürütmesinin durdurulması istemi reddedilmiştir. Söz konusu karara karşı davacı tarafından İstanbul Bölge İdare Mahkemesi Altıncı İdare Dava Dairesi nezdinde yapılan 2021/916 YD itiraz numaralı itiraz yine, "itiraz istemine konu edilen mahkeme kararı uygun görüldüğünden” reddedilmiştir. 
şart ve usulüne ilişkin kural ihdas eden idarenin, toplantı usulüne ilişkin herhangi bir düzenleme yapmamış veya yapılmış bir düzenlemeye atıfta bulunmamış olmasını bir 'unutkanlık' ya da 'ihmal' olarak düşünmek mümkün gözükmemektedir. Nitekim Uygulama Yönetmeliği’nin ilk halinde bu konuya ilişkin düzenleme de yer almaktadır ${ }^{67}$. İdare, Yönetmelik’te değişiklik yapmak suretiyle, Uygulama Yönetmeliği'nin ilk halinde var olan bir usulden vazgeçmiştir. Yukarıda yer verdiğimiz yargı kararlarına ve uygulamaya bakıldığında, toplantı usulüne ilişkin kuraldan vazgeçme gerekçe ve amaçlarının gerçekleştiğini söylemek pek mümkün değildir. Uygulamada gerek mahkemelerin gerek maliklerin herhangi bir usul öngörülmemiş olmasına karşın noter marifetiyle tebligat yapılması şartını aradıkları müşahede edilmektedir. Bu nedenle, halihazırdaki hukuki durumun tespiti büyük önem arz etmektedir.

Peki, bu belirsizlik ne şekilde giderilecektir? Bu noktada, kat mülkiyeti/irtifakı kurulu olan veya kurulu olmayan taşınmazlar arasında ikili bir ayrım yapmak gerekmektedir. Zira KMK'da kat mülkiyeti/irtifakı kurulu taşınmazlarda, karar alma usulüne ilişkin hükümler bulunmaktadır ${ }^{68}$. Burada cevaplanması gereken soru ise, kat mülkiyeti/irtifakı kurulu olmayan riskli yapılarda, KMK hükümlerinin uygulanıp uygulanamayacağıdır.

Kat mülkiyeti/irtifakı kurulu ve 6306 sayılı Kanun kapsamında riskli yapı olarak belirlenmiş taşınmazlara ilişkin olarak KMK ile 6306 sayılı Kanun hükümleri arasında bir farklılık bulunması durumunda, özel ve sonraki kanun olması nedeniyle, 6306 sayılı Kanun’un uygulanacağına kuşku yoktur. Ancak, bu nitelikteki taşınmazların kısmen veya tamamen KMK kapsamı dışına çıkarıldığına ilişkin ne 6306 sayılı Kanun'da ne KMK'da bir düzenleme vardır. Bu nedenle, - her ne kadar 6306 sayılı Kanun ve alt mevzuatıyla getirilmek istenen bu olmasa da - riskli yapılarda, 6306 Kanun'la bağdaştı̆̆ı ölçüde KMK hükümlerinin uygulanacağını söylemek yanlış olmayacaktır. Bu durumda, kat mülkiyetine tabi binalar bakımından çağrı şekline ilişkin olarak KMK md.29 f.2 hükmünün göz önünde bulundurulması gerekecektir ${ }^{69}$.

67 Uygulama Yönetmeliği md.15/2: "Riskli yapılarda, Kanunun 6 ncı maddesinin birinci fikrası uyarınca, parsellerin tevhit edilmesine, münferit veya birleştirilerek veya imar adası bazında uygulama yapılmasına, yeniden bina yaptırılmasına, payların satışına, kat karşılı̆̆ veya hasılat paylaşımı ve diğer usuller ile yeniden değerlendirilmesine esas karar alınmak üzere, yöneticinin veya denetçinin veya kat maliklerinin üçte birinin istemi üzerine, noter vasıtası ile yapılacak tebligat ile kat malikleri kurulu toplantıya çağrılır." [Uygulama Yönetmeliği’nin ilk hali için bkz RG 15.12.2012/28498]

$68 \boldsymbol{B} \boldsymbol{k} z$ KMK md.29 vd.

69 İnal (n 58) 106-107. 6306 sayılı Kanun m.6 hükmü çerçevesinde karar alınacak toplantı çağrısının TK Ek m.1 uyarınca fiilen oturana yapılmak veya apartman girişinde bulundurulacak ilan tahtasına asılmak suretiyle yapılamayacağı, bu şekilde yapılan çağrının 6306 sayılı Kanun kapsamında geçerli bir tebligat sayılamayacağı hususunda $\boldsymbol{b} \boldsymbol{k} z$ Yağc1 (n 58) 170-171. Yazar'a göre, “söz konusu hüküm kat mülkiyeti kanunun uygulandiğ 1 hallerde ve 'apartman yönetimine ve ortak giderlere ilişkin tebligatlar' hakkında geçerlidir. Oysa kentsel dönüşüm uygulaması, kat mülkiyeti kanununa tabi olmadığı gibi, mülkiyetin esasını ilgilendiren ve apartman yönetimi ve giderlerinin çok üzerinde öneme sahip bir konudur. Bu sebeple de söz konusu tebliğ usulünün kentsel dönüşüm konulu bir kat malikleri toplantısı bakımından uygulanmaması gerekir. Kaldı ki 6306 sayılı Kanunun riskli yapı tespitinin tebliğine dair 5/3 hükmü, tebliğe rağmen 2/3 çoğunlukla anlaşma sağlanamamasına dair $\quad 6 / f .2$ hükmü, bu kanun uyarınca tesis edilen idari işlemlere karşı dava açma süresinin tebligattan itibaren başlayacağına dair 6/f.9 hükmü dikkate alındığında, 7201 s. Tebligat Kanunun Ek m.1 hükmü uyarınca fiilen oturana ve/veya ilan tahtasına asılma suretiyle çağrı yapılmasının, kural olarak, 6306 sayıl Kanunun uygulama alanı kapsamında geçerli bir tebligat sayılamayacağı kanaatindeyiz." Fakat ne 6306 sayılı Kanun'da ne de 7201 sayılı Tebligat Kanunu’nda kentsel dönüşüm uygulamalarında KMK’de öngörülen tebligat hükümlerinden sapılacağına dair bir hüküm bulunmaktadır. Mevzuatta düzenlenmemiş olmasına karşın, ayrıksı bir tebligat usulünün benimsenmesi 
KMK'nın bu hükmü uyarınca yapılacak toplantı çağrısı önemli bir sebebin çıkması halinde, yöneticinin veya denetçinin ya da kat maliklerinden üçte birinin istemi üzerine ve toplantı için istenilen tarihten en az on beş gün önce bütün kat maliklerine imzalattırılacak bir çağrı veya bir taahhütlü mektupla, toplantı sebebi de bildirilmek şartıyla, kat malikleri kurulu her zaman toplanabilir ${ }^{70}$.

Kat mülkiyeti/irtifakı kurulmamış veya terkin edilmiş paylı mülkiyete tabi yapılar bakımından ise paydaşların toplantı yapmasına ve toplantıya çağırılması usulüne ilişkin bir düzenleme mevzuatta bulunmamaktadır. Paydaşlar arasında oybirliği sağlanamaması durumunda, paylı mülkiyete tabi bir riskli yapıya ilişkin olarak karar alınabilmesi için toplantı yapılması zorunluluğuna işaret eden açık bir hüküm 6306 sayılı Kanun ve Uygulama Yönetmeliği'nde yer almamaktadır. Mevzuatımızda bu hususta bir kural yer almadığı için, bu durumda 6306 sayılı Kanun ve Uygulama Yönetmeliği’nin lafzı ve amacı doğrultusunda hareket etmek gerekmektedir ${ }^{71}$.

Uygulama Yönetmeliği'nde toplantı usulü hakkında mülga kanun döneminde var olan usul kaldırılmış; 2/3 çoğunluktaki paydaşların karar vermesi yeterli görülmüş; muhalif paydaşlara ise alınan karara Uygulama Yönetmeliği md.15 f.2 uyarınca sonradan katılma imkânı tanınmıştır. Dolayısıyla kat mülkiyeti/irtifakı kurulmamış veya terkin edilmiş paylı mülkiyete tabi yapılar bakımından mevzuatın lafzının ve amacının 'yeter ki pay satışına ilişkin 2/3 çoğunlukla alınmış bir karar olsun' yönünde olduğu gerçeğinden hareket edilmelidir. Bu yapılar bakımından, KMK'da öngörülen usulün geçerli olmadığı; bu durumda olan taşınmazlar hakkında paydaşların dürüstlük kuralı çerçevesinde iradelerini ortaya koymalarına imkân tanınarak, en az 2/3 çoğunlukla alınan bir kararın yeterli kabul edilmesi gerektiği söylenebilecektir.

\section{RAYIÇ BEDELIN TESPIT ETTIRILMESI}

Riskli yapı tespiti kararının ardından, maliklerce alınan karara katılmayan muhalif paydaşlara ait taşınmazların değeri, satış öncesinde Sermaye Piyasası Kurulu ["SPK”] lisanslı gayrimenkul değerleme

halinde, kanun koyucu yerine geçilmesinin yanı sıra, kanun koyucunun “ivedi” kentsel dönüşüm isteğinin önüne uzun yıllar alabilen tebligat sorunu çıkabilecek; kat malikleri kurulu toplanana kadar yapının yıkımı ve kat maliklerinin mağduriyeti söz konusu olabilecektir. Zira uygulamada da uzun yargılama sürelerinin en büyük nedenlerinden birinin 'uzun süren tebligat süreçleri' olduğu bilinmektedir. Bu nedenle, kat mülkiyeti/irtifakı kurulu riskli yapılarda, KMK ve TK Ek Madde 1 hükümlerine uygun tebligatı, usulüne uygun olarak yapılmış bir tebligat olarak kabul etmenin hem mezkûr kanunun lafzına hem de 6306 sayılı Kanun’un ruhuna uygun olduğu kanaatini taşımaktayız.

70 Bu yönde $\boldsymbol{b} \boldsymbol{k} \boldsymbol{z}$ Yargitay 20 HD, E 2019/4723 K 2020/585, 10.02.2020; Yargitay 20 HD, E 2019/931 K 2019/3370, 13.05.2019; Yargitay 20 HD, E 2017/3690 K 2017/9936, 23.11.2017.

71 Bu boşluğun KMK md.29 f.2 hükmünün kıyasen uygulanması suretiyle doldurulması hem amaca uygun hem de pratik bir çözüm olacağı yönünde $\boldsymbol{b} \boldsymbol{k} z$ Yağcı (n 58) 171. 
şirketince tespit ettirilmelidir ${ }^{72} 73$. Uygulama Yönetmeliğìnde rayiç bedel tespitine konu olacak "taşınmaz" tanımlanmıştır. Buna göre taşınmaz, "22/11/2001 tarihli ve 4721 sayılı Türk Medeni Kanunu’nun 704 üncü maddesi uyarınca taşınmaz mülkiyeti kapsamma giren arazi, tapu kütüğünde ayrı sayfaya kaydedilen bağımsız ve sürekli haklar ile kat mülkiyeti kütüğ̈̈̈ne kayıtl bağımsız bölümleri” olarak tanımlanmaktadır.

Rayiç bedelin doğru tespiti, muhalif paydaşların mülkiyet hakkı bakımından büyük önem arz etmektedir. Zira, pay satışına esas alınacak rayiç değer, maliklerce SPK lisanslı değerleme kuruluşlarına tespit ettirilmiş olan taşınmazın değeri de gözetilerek Bedel Tespiti Komisyonunca belirlenmektedir ${ }^{74}$. Nitekim uygulamada, Bedel Tespit Komisyonunca belirlenen bedel ile değerleme kuruluşu tarafından saptanan bedel arasında çok da fark olmadığı görülmektedir. Bu nedenle, değerleme raporunda tespit edilen rayiç değerin, muhalif paydaşın pay satışından elde edeceği tutarın temelini oluşturacağını söylemek yanlış olmayacaktır.

Peki bu tespit ne zaman yaptırılacaktır? 6306 sayılı Kanun ve Uygulama Yönetmeliğìnde riskli yapı tespiti kararı sonrasındaki pay satışı şartlarının hangi sırayla gerçekleştirileceğine ilişkin bir düzenleme yer almamaktadır. Bu yönde bir düzenlemenin olmayışı, maliklerin bu anlamda bir usul sorunuyla karşı karşıya kalmalarını önleme ve dönüşümün hızlı şekilde gerçekleştirilmesini sağlama adına, kanun koyucunun bilinçli bir tercihi olduğu şeklinde yorumlanabilir. Buna mukabil, rayiç bedel tespitinin en az $2 / 3$ çoğunlukla pay satış kararının alınmasından sonra yapılacağı söylenebilecektir. Zira, ancak yapılacak kat malikleri toplantısından veya - kat mülkiyeti/irtifakı bulunmayan taşınmazlar açısından - en az 2/3 çoğunlukla pay satış kararının alınmasından sonra herhangi bir paydaşın alınacak karara muhalif olup olmadığı; muhalif kalan paydaş varsa da hangi paydaş(lar)ın payının satışa konu olacağı belli olacaktır. Alınan karar(lar)a muhalif kalarak paylarının satışa konu edilmesi kararlaştırılan maliklere ait taşınmazın rayiç bedeli tespit ettirilecek; sonrasında bu pay satışa konu edilebilecektir. Nitekim, Uygulama Yönetmeliğỉnin "açık artırma usulü ile satış" başlıklı 15/A maddesinde, pay satı̧sı için istenilen belgeler arasında, "(ï)çte iki çoğunlukla alınan karara katılmayan maliklere ait taşınmazların Sermaye Piyasası Kuruluna kaytth olarak faaliyet gösteren lisanslı değerleme kuruluşlarına tespit ettirilen değerine ilişkin belgeler” yer almaktadır.

Şu hâlde, en az üçte iki çoğunlukla alınan karara katılmayan malikler ve payları, ancak yapılacak kat malikleri toplantısından veya en az $2 / 3$ çoğunlukla maliklerin anlaşmasından sonra ortaya

726306 sayılı Kanun md.6 f.1: “[...] Bu çerçevede, parsellerin tevhit edilmesine, münferit veya birleştirilerek veya imar adası bazında uygulama yapılmasına, yeniden bina yaptırılmasına, payların satışına, kat karşılı̆̆ı veya hasılat paylaşımı ve diğer usuller ile yeniden değerlendirilmesine sahip oldukları hisseleri oranında paydaşların en az üçte iki çoğunluğu ile karar verilir. Bu karara katılmayanların bağımsız bölümlerine ilişkin arsa payları, Bakanlıkça rayiç değeri $\quad t$ e s $p \quad i t$ ettirilerek bu değerden az olmamak üzere anlaşma sağlayan diğer paydaşlara açık artırma usulü ile satılır [...]" Yönetmelik md.15/A f.1/c: "Riskli alanlar, rezerv yapı alanları ve riskli yapıların bulunduğu parsellerde hisseleri oranında paydaşların en az üçte iki çoğunluğu ile alınan karara katılmayan maliklerin arsa paylarının satışı için [...] c) Üçte iki çoğunlukla alınan karara katılmayan maliklere ait taşınmazların Sermaye Piyasası Kuruluna kayıtl olarak faaliyet gösteren lisansl değerleme kuruluşlarına tespit ettirilen değerine ilişkin belgeler [...] ile birlikte yazılı olarak Müdürlüğe veya Bakanlıkça yetki devri yapılması durumunda İdareye müracaatta bulunulur. Satış işleminin yapılabilmesi için yapıların yıktırılmış olmasi gerekmez."

73 Uygulamada, değerleme şirketinin lisans belgeleri raporun arkasına eklenmesi değerleme raporunun tüm sayfalarının paraflı, sonuçlar kısmının ise kaşeli ve ıslak imzalı olması istenilmektedir.

74 B $\boldsymbol{k z}$ Uygulama Yönetmeliği md.15/A/3. 
çıabilecektir. Maliklerin oy birliğiyle karar alması durumunda ne pay satışına ne de SPK lisanslı değerleme kuruluşunca yapılacak bir bedel tespitine gerek olacaktır. Maliklerce en az 2/3 çoğunlukla alınan karara katılmayan muhalif paydaşların varlığı halinde ise, bu tespit ve pay satış kararı alındıktan sonra, taşınmazların SPK lisanslı değerleme kuruluşunca bedeli tespit ettirilebilecektir.

Burada, yapılacak bedel tespitinin zamanı da önem taşımaktadır. Her ne kadar hukuken bir zorunluluk olmasa da bina yıkılmadan bedel tespitinin gerçekleştirilmesinde fayda bulunmaktadır. Zira, bedeli tespit edilecek taşınmazlar içerisinde "bağımsız bölümler" de yer almaktadır. Binanın yıkılarak, kat mülkiyeti/irtifakının terkin edilmesi halinde, bağımsız bölümler ortadan kalkacak ve rayiç bedel tespiti zorlaşabilecektir. Bu nedenle, taşınmaza ilişkin rayiç bedel tespitinin, maliklerce en az $2 / 3$ çoğunlukla karar alınmasından sonra ve/fakat bina yıkılmadan önce gerçekleştirilmesinin isabetli olacağ kanaatini taşımaktayız $^{75}$.

Öte yandan ne 6306 sayılı Kanun, ne de Uygulama Yönetmeliği’nde değerleme raporunun alınmasına ilişkin karar için ayrı bir toplantı/karar gerekip gerekmediği düzenlenmiştir. Pay satışı kararının alınmasından sonra, bu değerleme için ayrıca bir karar alınabileceği gibi; muhalif paydaşların payının satışına ve bunlara ilişkin değerleme raporu alınacağına aynı kararda da yer verilebilecektir ${ }^{76}$. Dolayısıyla değerleme raporu alınması kararı, her ne kadar 'pay satışı kararı̉nın doğal bir sonucu olsa da bu yönde ayrıca karar alınması gerektiği kanaatindeyiz.

Zira, bu değerleme raporunun alınması, maliklere ayrı bir mali külfet yükleyebilecektir. Uygulamada çoğu zaman yapıda dönüşümü sağlayacak müteahhit tarafından bu mali külfete katlanılmaktaysa da maliklerin kendilerinin de dönüşüm uygulamalarını gerçekleştirebilecekleri gözden kaçırılmamalıdır. Böyle bir durumda, genel hükümler dahilinde harekete etmek gerekecektir. Kat mülkiyeti kurulu taşınmazlar bakımından, KMK md.20'de ${ }^{77}$, - aksine bir karar alınmamışsa - kat maliklerinin ana gayrimenkulün giderlerine katılmakla yükümlü olduğunu ve ortak yer veya tesisler üzerindeki kullanma hakkından vazgeçmek veya kendi bağımsız bölümünün durumu dolayısıyla bunlardan faydalanmaya lüzum ve ihtiyaç bulunmadığını ileri sürmek suretiyle bu gider ve avans payını ödemekten kurtulamayacağını hüküm altına almıştır. Kat mülkiyeti bulunmayan taşınmazlarda ise bu sefer TMK’nın giderler ve yükümlülüklere ilişkin 694. maddesini ${ }^{78}$ uygulamanın isabetli olacağ 1 görüşündeyiz. Payı satışa konu edilecek muhalif

75 Aynı yönde bkz "Anayapının yıktırılmasından sonra dairelerin fiziksel durumlarının kantlanabilmesi mümkün olamayacağından, ortada tipik bir "delillerin kaybolması" durumu söz konusudur". Özsunay (n 11) 35. Yazar bu sakıncanın önlenmesi için, yıkımdan önce 'delil tespiti davası' açılmasını önermektedir.

76 B $\boldsymbol{k} z$ Uygulama Yönetmeliği md.15 f.2.

77 KMK md.20: "Kat maliklerinden her biri aralarında başka türlü anlaşma olmadıkça: [...] b) Anagayrimenkulün sigorta primlerine ve bütün ortak yerlerin bakım, koruma, güçlendirme ve onarım giderleri ile yönetici aylı̆̆ gibi diğer giderlere ve ortak tesislerin işletme giderlerine ve giderler için toplanacak avansa kendi arsa payı oranında; katılmakla yükümlüdür [...] Kat malikleri ortak yer veya tesisler üzerindeki kullanma hakkından vazgeçmek veya kendi bağımsız bölümünün durumu dolayısıly bunlardan faydalanmaya lüzum ve ihtiyaç bulunmadiğın ileri sürmek suretiyle bu gider ve avans payın ödemekten kaçınamaz."

78 TMK md.694: "Payl mülkiyetten doğan veya payl malı ilgilendiren yönetim giderleri, vergiler ve diğer yükümlülükler, aksine bir hüküm bulunmadıkça, paydaşlar tarafindan payları oranında karşılanır. Payına düşenden fazlasını ödemiş bulunan paydaş, diğerlerine payları oraninda rücu edebilir." 
paydaşların böyle bir mali yükümlülük altına sokulmasının adil olmayacağı düşünülebilecekse de SPK lisanslı değerleme kuruluşunca yapılacak doğru bedel tespitinde, payı satışa konu edilecek malikin de menfaati bulunmaktadır. Bu nedenle, bu hususta genel hükümlerden ayrılmayı gerektiren bir durum olmadığı kanaatindeyiz.

Rayiç bedelin tespitinin hangi değer üzerinden hesaplanacağı konusu ise üzerinde durulması gereken bir başka husustur. 6306 sayılı Kanun, pay satış kararının alınmasına yıkımdan önce de sonra da imkan tanımaktadır. Eğer yapı yıktırılmamışsa, rayiç bedel değerinin 6306 sayılı Kanun’un 6. maddesi doğrultusunda arsa payı üzerinden hesaplanması gerekecektir ${ }^{79}$. Eğer yapı yıkılmış ise de hisseye ait rayiç bedel değerinin taşınmazın toplam değerinin hisse oranına bölünmesiyle hesaplanması gerektiğini düşünüyoruz.

Nitekim, 6306 sayılı Kanun’un 6/1.maddesine göre, “üzerindeki bina yıkılarak arsa hâline gelen taşınmazlarda daha önce kurulmuş olan kat irtifakı veya kat mülkiyeti, [...] tapu müdürlüğünce resen terkin edilerek, önceki vasfı ile değerlemede bulunularak [...] malikleri adına payları oranında tescil edilir". Görüldüğü üzere, kat mülkiyeti/kat irtifakı kurulu bina yıkıldıktan sonra, maliklerin payları, "önceki vasfı ile değerlemede bulunularak" adlarına tescil edilecektir. Tescil işlemi, idare işlevine ilişkin bir faaliyettir ${ }^{80}$. Bu cümleden hareketle, kat mülkiyeti/ irtifakı kurulurken, bağımsız bölümün sahip olduğu vasıflar dikkate alınarak hesaplanan arsa payının, pay hesabına esas alınacağını; rayiç bedel hesabına konu edilecek payın ise, arsa payı esas alınarak hesaplanan ve tapuya bu şekilde tescil edilen hisse olduğunu söylemek mümkündür ${ }^{81}$.

79 Her bir bağımsız bölümün yüzölçümü, biçimi, kaçıncı katta bulunduğu, cadde veya sokağa cepheli olup olmadığı, güneşten yararlanma olanağı gibi unsurlar dikkate alınarak hesaplanan arsa payı hakkındaki açıklamalar için $\boldsymbol{b k z}$ "Satışın Konusu: Pay (Hisse)" başlı̆̆ı.

Arsa payının gerçek değeri üzerinden satışı konu edilebilmesi ve mülkiyet hakkının ihlal edilmemesi için, arsa payının doğru hesaplanmış olması gerektiğine kuşku bulunmamaktadır. Arsa payı hesabının doğru yapılmamış olması ve gerçeği yansıtmadığı ihtimalinde, arsa payı düzeltim davası açılabileceği hususunda $\boldsymbol{b} \boldsymbol{k} z$ İnal (n 58) 39. Arsa payı düzeltim davası hakkında ayrıntılı bilgi için ayrıca $\boldsymbol{b} \boldsymbol{k} z$ Etem Saba Özmen ve Berna Çakmak, '6306 Sayılı Yasa Uygulamalarında Arsa Payının Düzeltilmesi Davasına İliş̧kin Hüküm ve Sonuçlar’ İstanbul Barosu Dergisi (2013) 87(5) 725, 725-750.

80 Danıştay 14 D, E 2019/79 K 2019/189, 17.01.2019: "Davacılar tarafından 6306 sayıl Kanun kapsamında yıkılan riskli yapıda dükkan olan taşınmazlarının niteliğinin mevcut duruma göre tescil edilmesi gerektiğinden bahisle 2577 sayll Kanunun 10.maddesi uyarınca yapıldığı anlaşılan başvurunun reddine ilişkin İstanbul Valiliği Çevre ve Şehircilik İl Müdürlüğünün 20/06/2016 günlü, E:20722 sayll işleminin ilgililerin hukuksal durumunu etkileyen, kamu gücüne dayanan, tek yanl, kesin ve yürü̈tülmesi zorunlu idari işlem niteliğinde olduğu, bu işleme karşı açılan davanın idari yargı tarafindan çözümlenmesi gerektiği açıktır".

81 Riskli yapılarda maliklerce gerçekleştirilecek dönüşüm uygulamalarında, maliklerce aksi yönde yapılmış bir anlaşma yoksa "önceki vasfı ile değerlemede bulunularak" ifadesini, "önceki vasfı ile hesaplamada bulunularak" şeklinde anlamak daha doğru olacaktır. Nitekim İnal'a göre de burada, "tapu müdürlüğünce resen yapılacak işlem, kat irtifakı veya kat mülkiyetinin terkini ile, taşınmazın, malikleri adına payları oranında tescilinden ibarettir. Bu tescil sırasında değerleme veya anlaşma şartları tapuda belirtilecektir. Burada tapu memuru tarafindan tescil edilebilecek paylar ise, kat mülkiyeti sicilinde gösterilmiş olan arsa paylarnndan ibarettir. Yoksa, tapu müdürlüğünün, resen değerleme yapmak suretiyle, kat mülkiyeti sicilindeki arsa paylarından farkh bir pay tespiti ve tescili yapabilmesi mümkün değildir". İnal (n 58) 52-53.; Aksi yönde $\boldsymbol{b} \boldsymbol{k} z$ Üstün, Kentsel Dönüşüm Hukuku (1. Bası, On İki Levha Yayıncllık 2014) (n 3) 155-156; Zekeriya Kurşat, '6306 Sayılı Afet Riski Altındaki Alanların Dönüştürülmesi Hakkında Kanunun Özel Hukuk Alanındaki Etkileri' iç Melikşah Yasin ve Cenk Şahin (edr), Kentsel Dönüşüm Hukuku (2. Bası, On İki Levha Yayıncılık 2015) 40-41. 


\section{PAY SATIŞI KARARINA ILIŞKIN IHTARNAME GÖNDERILMESi}

Pay satış kararı alındıktan sonra, alınan kararın, anlaşma şartlarını içeren teklifle birlikte, karara muhalif kalan paydaş(lar)a noter vasıtasıyla veya 7201 sayılı Tebligat Kanunu [“TK”] uyarınca tebliğ edilmesi gerekmektedir. (Uygulama Yönetmeliği, Madde 15/A/1/b) Uygulama Yönetmeliği’nin bu maddesinin önceki halinde, satışa ilişkin işlemin tebliğinin maliklerin MERNİS adresine yapılacağı belirtilmekteydi. 21.06.2019 tarih ve 30808 sayılı Resmi Gazete'de yayınlanan değişiklikle birlikte, muhalif kalan paydaş(lar)a noter vasıtasıyla veya 7201 sayılı TK uyarınca tebliğ edilmesi usulü benimsenmiştir. Bu usulün belirlenmesinin, maliklere ulaşılamaması halinde nasıl tebligat yapılacağına ilişkin belirsizlik oluşturduğu; bu belirsizliğin malikten habersiz satışın yapılabilmesine imkân tanıyacağı ve mülkiyet hakkını ihlal edeceği gerekçesiyle hukuka aykırı olduğu ileri sürülmüşse de Danıştay bu iddiayı yerinde bulmamıştır ${ }^{82}$.

Uygulama Yönetmeliğiinin 15/2. maddesinde, gönderilecek tebligatta, “[...] on beş gün içinde kararın ve teklifin kabul edilmemesi halinde arsa paylarının, Bakanlıkça tespit edilecek veya ettirilecek rayiç değerden az olmamak üzere anlaşma sağlayan diğer paydaşlara açık artırma usulü ile satılacağı, paydaşlara satış gerçekleştirilemediği takdirde, [...] anlaşma sağlayan diğer paydaşlara veya yapılan anlaşmaya uyularak işlem yapılmasını kabul etmek şartıyla üçüncü şahıslara satılacağı bildirilir”.

İhtarnamede, maliklerce alınan karar ile birtakım belgelerin ve ibarelerin yer alması gerektiği belirtilmiştir. Buna göre ihtarname ekinde, karara katılmayan malikin 2/3 çoğunlukla alınan karara katılma/katılmamasına etki edecek belgeler yer almalıdır. Bu kapsamda, ihtarname ekinde, imzalı karar tutanağı, üzerinde çoğunlukça mutabakat sağlanan teklif/arsa payı karşılığı inşaat sözleşmesi ve kat paylaşım planı ile bu nitelikteki diğer belgelerin yer alması gerektiği söylenebilecektir.

Uygulamada, mevzuatta öngörülmemiş olmasına karşın, ihtarname içeriğinde bir önceki paragraftakilere ek olarak, Uygulama Yönetmeliği md.15/A f.11'de yer alan "Yapılan ilk satışta anlaşma sağlayan paydaşlara satış gerçekleştirilemediği takdirde, anlaşma sağlayan paydaşlara veya anlaşma sağlayan paydaşların kararı ile yapılan anlaşmaya uyularak işlem yapılmasını kabul etmek şartıyla üçüncü şahıslara satış yapılıncaya kadar satış işlemi tekrarlanır.” ibaresinin yer almasının idarelerce istendiği görülmektedir.

Yapılan bu tebligat sonrasında muhalif paydaş, on beş gün içerisinde $2 / 3$ çoğunluğun kabul ettiği anlaşmaya katıldığına yönelik irade beyanını - herhangi bir kayıt veya şarta bağlamaksızın ${ }^{83}$ - ortaya

82 Danıştay 6 D, E 2019/2494 K 2019/5508, 12.06.2019:“[...] (K)anun koyucu tarafindan idareye tanman düzenleme yetkisi uyarınca dava konusu Yönetmelik kurallarının öngörüldüğü, normlar hiyerarşisine uygun olarak, kamu yararı ve hizmet gerekleri doğrultusunda düzenleme yapıldığı sonucuna ulaşıldığından, yukarıda belirtilen hükümlerde hukuka aykırılık bulunmamaktadir [...]".

83 Yapılan ihtar neticesinde, muhalif paydaşın ihtirazı kayıtla anlaşmaya katılacağını beyan etmesinin, anlaşmaya katılma iradesi olarak nitelendirilemeyeceği, bu nedenle muhalif paydaşın payının sattırılmasının hukuka uygun olduğu yönünde bkz. "[...] (D)avacının ihtirazı kayıt ileri sürmesinin 2/3 çoğunluğu sağlayan paydaşlar tarafından alınan karara katılmadı̆̆ı sonucunu doğuracağı açıktır. Zira yukarıda belirtilen mevzuat hükümlerinde, hissesi azınlıkta kalanların bu 
koyarak, payının satışa çıkmasını engelleyebilir. Malik paydaş(lar) tarafından on beş gün içerisinde maliklerce alınan karara katılma iradesi sergilenmemesi halinde, malikin payına ilişkin olarak pay satı̧s süreci devam edecektir.

\section{E. YAPININ YIKILMIŞ OLMASI}

Pay satışının gerçekleştirilebilmesi için, riskli yapının yıkılmasının şart olup olmadığı üzerinde ayrıca durulması gerekmektedir. Uygulama Yönetmeliği’nin 15/A/1-ç maddesinde açıça “(s)atış işleminin yapılabilmesi için yapıların yıktırılmış olması gerekmez" hükmü yer almaktadır. Ayrıca satı̧̧ işleminin gerçekleştirilebilmesi için istenilen belgeler arasında, yapının yıkıldığına ve kat mülkiyetinin/irtifakının terkin edildiğine ilişkin bir belge de aranmamaktadır. Bu hükümlerin lafzından yola çıkarak, kural olarak, yapı yıktırılmamışken pay satışının mümkün olduğu söylenebilecektir. Buna karşın, farklı mülkiyet türleri açısından konunun ele alınması gerektiğini düşünmekteyiz.

\section{KAT MÜLKIYETIIIRTIFAKI KURULU TAŞINMAZLAR AÇISINDAN DEĞERLENDIRME}

Hatırlanacağ üzere arsa payı, kat mülkiyetinin/irtifakının kurulu olduğu yapılarda söz konusu olabilmektedir. KMK incelendiğinde, arsa payı ile kat mülkiyeti arasında ayrılmaz, sıkı bir ilişki olduğu anlaşılmaktadır ${ }^{84}$. KMK md.5/1E2'ye göre, "( $k$ )at mülkiyetinin başkasına devri veya miras yoluyla geçmesi halinde, ona bağl arsa payı da birlikte geçer; arsa payı, kat mülkiyetinden veya kat irtifakından ayr olarak devredilemeyeceği gibi, miras yoluyla da geçmez ve başka bir hakla kayıtlanamaz". Görüldüğü üzere KMK’ya göre arsa payının, kat mülkiyeti veya kat irtifakından bağımsız şekilde devri mümkün değildir. Nitekim Yargıtay kararlarında da ${ }^{85}$ arsa payı ile kat mülkiyeti arasındaki bağın önemine "Arsa paysız bağımsız bölümün tescili olanaksızdır [...]" denerek dikkat çekilmektedir.

Şu hâlde, KMK ile 6306 sayılı Kanun ve Uygulama Yönetmeliği arasında arsa payının, kat mülkiyetinden/irtifakından ayrı şekilde satışı konusunda bir farklılık-karmaşa olduğu aşikardır. 6306 sayılı Kanunun hem sonraki hem de özel kanun olmasından hareketle, 6306 sayılı Kanun'un ve Uygulama Yönetmeliği’nin düzenlemeleri ekseninde konunun çözüme kavuşturulmasının doğru olacağ 1 düşünülebilecektir. Ancak bu durumda da arsa payının satışı işleminden sonra, arsa payı maliki ile bağımsız bölüm maliki farklılaşacak; arsa payı malikinin hakkının tapu siciline tescili

yenilemeleri sürüncemede bırakmaması için en az 2/3 arsa payı çoğunluğu sağlayan diğer maliklere işlemleri yürütmesi için yetki verilmiş olup olayda 2/3 arsa payı maliki müdahil firma tarafından, davacı tarafindan ihtirazı kayıtla yapılan bu teklifi kabul edilmeyerek davacıya ait arsa payının satışına yönelik işlemlere başlanılmasında ve İstanbul Çevre ve Şehircilik İl Müdürlüğ̈̈ tarafından davacıya ait arsa payının satışa çıkarılmasına dair işlemde hukuka aykırılık bulunmadığından, dava konusu işlemin iptali yolunda verilen İdare Mahkemesi kararında hukuki isabet görülmemiştir[...]”, Danıştay 14 D, E 2018/103 K 2018/575, 14.02.2018.

84 Arsa payının kat mülkiyeti ile sınırlı olduğuna ilişkin $\boldsymbol{b} \boldsymbol{k} z$ Özmen / Şengül (n 26) 23.

85 Yargitay 14 HD, E 2004/571 K 2004/2394, 29.03.2004; Yargitay 14 HD, E 2001/8352 K 2001/8615, 10.12.2001; Yargitay 14 HD, E 1976/6278 K 1977/518, 25.01.1977. 
sorunu gündeme gelecektir ${ }^{86}$. Bu sorunun çözümü ise, yine yapının yıkılarak, kat mülkiyetinin/ irtifakının terkinine ${ }^{87}$ bağlı olacaktır.

6306 sayılı Kanunun amacının, can ve mal güvenliği üzerinde olası afetler nedeniyle var olan riskleri kaldırmak, kentsel alanların ve yapıların planlama ve şehircilik ilkelerine uygunluğunu sağlamak olduğu daha önce ifade edilmişti. Bu yüzden dönüşümün süratli bir şekilde gerçekleştirilmesinin esas olması ve pay satışı için yapının yıkılmış olma şartının aranmaması normal karşılanmalıdır. Ancak, 6306 sayılı Kanun ve Uygulama Yönetmeliği hükümleri doğrultusunda, kat mülkiyeti/ irtifakı kurulu taşınmazlarda, arsa payı satışının kat mülkiyeti/irtifakı terkin edilmeksizin tüm sonuçlarıyla gerçekleştirilmesi mümkün gözükmemektedir. Bu nedenle, kat mülkiyeti/irtifakı kurulu taşınmazlarda pay satışının gerçekleştirebilmesi için, KMK'da öngörülen kat mülkiyeti/irtifakı-arsa payı bağını koparılmaksızın, öncelikle yapının yıkılıp, kat mülkiyeti/irtifakının terkin edilmesi gerektiği kanaatini taşımaktayız. Bu terkin gerçekleştikten sonra ise, bir 'arsa payı satışı'ndan değil; 'pay satışı'ndan bahsedilebilecektir. Zira ortada kat mülkiyeti/irtifakı bulunmadığ için, ona bağlı bir arsa payından da söz edilemeyecektir ${ }^{88}$. Bu nedenle, kat mülkiyeti/irtifakı kurulu taşınmazlarda pay satışının gerçekleştirilebilmesi için, yapının yıkılmış olması bir şart olarak karşımıza çıkmaktadır.

\section{KAT MÜLKIYETI/IRTIFAKI KURULU OLMAYAN TAŞINMAZLAR AÇISINDAN DEĞERLENDIRME}

Kat mülkiyeti/irtifakının söz konusu olmadığı, paylı mülkiyete tabi riskli yapılar açısından yapının yıkılmış olup olmamasının pay satışına bir etkisi bulunmamaktadır. Zira, kat mülkiyetinin/irtifakının kurulu olmadığı paylı mülkiyete tabi taşınmazlarda, pay satışına konu edilmek istenilen pay, üzerindeki binadan bağımsız şekilde tasarruf edilebilir niteliktedir. Parsel üzerinde bulunan riskli yapının yıkılmamasının, tapuda gösterilen pay üzerinde gerçekleştirilecek tasarrufa engel niteliği yoktur. Bu nedenle, kat mülkiyeti/irtifakı kurulu olmayan riskli yapılarda, Uygulama Yönetmeliğinin

86 Nitekim KMK md.5 f.1'de "[...] arsa payı, kat mülkiyetinden veya kat irtifakından ayrı olarak devredilemeyeceği gibi..." denmekte; md.13 f.2'de “...kat mülkiyetine konu olan her bağımsız bölüm, kat mülkiyeti kütüğ̈̈nün ayrı bir sayfasına o bölüme bağh arsa payı ve anagayrimenkulün kayıtlı bulunduğu genel kütükteki pafta, ada, parsel, defter ve sayfa numaraları gösterilmek suretiyle tescil edilir[...]" denmekte; Tapu Sicil Tüzüğü md.8 f.1'de "Tapu siciline taşınmaz olarak şunlar kaydedilir: [...] Kat mülkiyetine konu olan bağımsız bölümler" denmekte; md.11'de "Ana taşınmazın bağımsız mülkiyete konu olan bölümleri, kat mülkiyeti kütüğünün ayrı sayfalarına kaydedilir.” denmekte; yine TMK md.998'de “Tapu siciline taşınmaz olarak şunlar kaydedilir:[...] Kat mülkiyetine konu olan bağımsız bölümler” denmekte, böylece arsa payı maliki ile bağımsız bölüm malikinin farklılaşmasının mümkün olmadığı gözler önüne serilmektedir.

876306 sayılı Kanun, md.6/1: “Üzerindeki bina yıkılarak arsa hâline gelen taşınmazlarda daha önce kurulmuş olan kat irtifakı veya kat mülkiyeti, ilgililerin muvafakatleri aranmaksızın Bakanlığın talebi üzerine ilgili tapu müdürlüğ̈̈nce resen terkin edilerek, önceki vasfı ile değerlemede bulunularak veya malik ile yapılan anlaşmanın şartları tapu kütüğ̈̈nde belirtilerek malikleri adına payları oranında tescil edilir."

"6306 sayılı Yasa uyarınca, kat mülkiyetinin binanın yıkılması ile sona ereceği ve terkinin açıklayıcı olacă̆ı; buna karşılık kat irtifakının binanın yıkılması ile değil kurucu terkin niteliğindeki terkinin yapılması ile sona ereceği kabul edilmelidir”. Kurşat (n 81) 41-42. Riskli yapı kararının 6306 sayılı Kanun’da belirlenmiş prosedür sonrası kesinleşmiş olmasının, kat mülkiyetini kendiliğinden sonlandırdığı; bu konuda 6306 Sayılı Kanun'un 3. maddesinde tapuya yapılan idari bildirim ve bu bildirime dayalı tapu dairesinin re’sen yapacağı terkinin artık kurucu değil bildirici nitelikte olduğu yönündeki aksi görüş için $\boldsymbol{b} \boldsymbol{k} \boldsymbol{z}$ Özmen / Çakmak (n 79) 745.

Bu hususta $\boldsymbol{b} \boldsymbol{k z}$ "Satışın konusu: pay (hisse)" başlı̆̆ı. 
15/A/1-ç maddesinde yer alan "(s)atış işleminin yapılabilmesi için yapıların yıktırılmış olması gerekmez" kuralı uyarınca yapı yıkılmaksızın pay satış işleminin gerçekleştirilebileceğini söylemek mümkündür. Bir diğer ifadeyle, anılan niteliği haiz taşınmazlarda, yapının yıkılmış olması, pay satışı için bir şart değildir.

\section{F. BAŞVURU YAPILMASI}

Pay satış için öncelikle bu istemle pay satışı işlemini gerçekleştirmeye Uygulama Yönetmeliğỉnin 15/A/1. maddesi uyarınca yetkili, Altyapı ve Kentsel Dönüşüm Müdürlüğüne; Çevre ve Şehircilik İl Müdürlüğüne veya yetki devri bulunan hallerde belediyelere başvurulması gerekmektedir.

Uygulama Yönetmeliğinnde pay satışına ilişkin başvurunun kim tarafından yapılacağına ilişkin bir düzenleme bulunmamaktadır. Paydaşlar dilerse aralarından birini veya müteahhit firma yetkilisini bu konuda yetkilendirebilecekleri gibi; genel hükümlerdeki temsil ilişkisi çerçevesinde tek paydaşın veya malikin başvurusunun da ortak yararın korunması kapsamında geçerli kabul edilmesi gerekmektedir ${ }^{89}$. Şu hâlde, muhalif azınlığın payının satışı için $2 / 3$ çoğunlukta yer alan paydaşların herhangi biri veya bu paydaşlar tarafından vekil olarak tayin edilen kişi tarafından Uygulama Yönetmeliği md.15/A/1'de sayılan belgeler ile ilgili idareye yazılı olarak başvuruda bulunulması yeterlidir. Bu başvuru, "(i)lgililer, haklarında idari davaya konu olabilecek bir işlem veya eylemin yapılması için idari makamlara başvurabilirler" şeklindeki IYYUK md.10 kapsamında gerçekleştirilen bir başvuru niteliğindedir.

Başvuru ekini oluşturacak belgeler, imzalı karar tutanağı, üzerinde çoğunluk tarafından mutabakat sağlanan arsa payı karşllığ inşaat sözleşmesi örneği, anlaşan paydaşlar tarafından müteahhit şirkete verilen vekaletnameler, muhalif paydaş(lar)a gönderilen ihtarname, rayiç bedel değerleme raporu olarak belirtilmiştir [Uygulama Yönetmeliği md.15/A/1].

Başvurunun zamanı açısından ise Uygulama Yönetmeliği’nde bir süre öngörülmediğinden, şartlar sağlandıktan sonra, dilendiği zaman başvuruda bulunulabilecektir. Dolayısıyla başvuru yapılmadığı takdirde, riskli yapının uygulamaya tabi tutulması ve pay satışı işlemi sürüncemede kalabilecektir.

Yapılan başvurunun geri alınıp alınmayacağı ise bu noktada üzerinde durulması gereken bir başka konudur. Burada, başvuruyu yapan kişi ve temsil kabiliyeti göz önünde bulundurulmalıdır. Paydaşlardan birinin yaptığı başvurunun, ortak yarar gereği yalnızca başvuruyu yapan paydaşın iradesiyle geri çekilmesi mümkün olmadığ gibi; başvuru yapma konusunda yetkilendirilmiş kişinin de başvurunun geri çekilmesi konusunda ayrıca yetkilendirilmedikçe pay satışı başvurusunu geri alamayacağının kabulü gerekmektedir. Şu hâlde, pay satış kararını alan, bu yönde irade sergileyen en az 2/3 çoğunluğu sağlayan aynı maliklerin, pay satış işlemi gerçekleşene kadar, 6306 sayılı Kanun kapsamında yeni bir karar alarak pay satışına ilişkin başvurularını geri almaları mümkündür ${ }^{90}$.

89 Etem Sabâ Özmen ve Gülşah Sinem Aydın, ‘6306 Sayılı Kanun Uyarınca Paylı Mülkiyet Sürecinde Paylaşma Davasına (İzale-i Şuyu) İlişkin Hüküm ve Sonuçlar’ Legal Hukuk Dergisi (2018) (188) 35, 60.

90 Aksi yönde $\boldsymbol{b} k \boldsymbol{z}$ İnal (n 58) 157; Özmen / Şengül (n 26) 127-128: “[...] Geçerli bir karar almaya yönelik irade beyanı 
Zira, burada İYUK md.10 kapsamında yapılmış bir başvuru ve bu idari başvurunun geri alınması söz konusudur. Söz konusu madde uyarınca, ilgililer haklarında bir idari işlem veya eylem tesis edilmesi amacıyla idareye başvurma hakkına sahiptir. Bu başvuruyu yapan kişi ya da kişilerin, yapmış oldukları başvuruyu, hukuki sonuçları doğmadan önce geri çekebilecekleri hususunda duraksama bulunmamaktadır ${ }^{91}$. Kurul halinde alınan kararlar neticesinde yapılan başvurularda, kurulun bir tüzel kişiliğin organı sıfatı bulunmakta ise, kişiliği temsilen kurulun kim veya kimlerden oluştuğu herhangi bir önem ifade etmemektedir. Ancak pay satış kararını alan malikler topluluğunda olduğu gibi, her bir iradenin ayrı ayrı birleşmek suretiyle hukuki sonuç doğurduğu durumlarda, topluluğu oluşturan katılımcıların kişilikleri önem arz etmektedir. Bu durumda, en az 2/3 çoğunlukla pay satışına karar alan maliklerin her birisinin iradesi birleşerek, pay satışına ilişkin usulün işletilmesi amacıyla idareye başvuru yapılmaktadır. Dolayısıyla başvuruyu yapan malik veya kanunî temsilcinin yapılan başvuruyu geri çekebilmesi için, karara katılan tüm maliklerin iradesinin bu yönde sergilenmiş olması şarttır.

\section{PAY SATIŞININ USULÜ}

6306 sayılı Kanun kapsamında pay satışı için yukarıda yer verilen şartlar sağlandıktan sonra, dönüşüm uygulamalarının gerçekleştirilebilmesi için idare aracılığıyla payın satışı söz konusu olacaktır. Bu satışa ilişkin usul de Uygulama Yönetmeliği’nde gösterilmiştir. Aşağıda bu usul, konunun anlaşılmasını kolaylaştırmak adına, satış öncesi satışa hazırlık aşaması ile satış aşaması olarak, iki aşamada ele alınacaktır.

\section{A. HAZIRLIK AŞAMASI}

Pay satışı işleminin gerçekleştirebilesi için, öncesinde idare tarafından gerçekleştirilmesi gereken iş ve işlemler bulunmaktadır. Pay satışı usulünün birer parçası olarak, bu iş ve işlemlerin - mümkün olduğunca - kronolojik olarak ele alınması gerekmektedir.

\section{BAŞVURUNUN DEĞERLENDIRILMESI VE TAPU KÜTÜĞÜNE ŞERH VERILMESi}

Pay satışı için yapılan başvurunun ne süre içerisinde ve ne şekilde değerlendirileceğine ilişkin bir düzenleme mevzuatta bulunmamaktadır. Öncelikle ifade etmek gerekir ki, bu konunun Uygulama Yönetmeliğinde düzenlenmesi faydalı olacaktır. Başvuru üzerine, satışa yetkili idare tarafından, başvuru ve ekinde yer alan belgelerin, pay satış şartlarının sağlanıp sağlanmadığı yönünden inceleneceği söylenebilecektir. Nitekim, maliklerce alınan karara muhalif kalan malikin pay satışı kararı, imzalanan kat malikleri toplantısında kabul edilen sözleşmenin kendi içinde çelişkiler içerdiği

niceliği ne ise, aynı veya daha fazla bir niceliğe sahip ortak malik irade beyanıla karardan dönme veya fesih mümkündür."

91 "[...] (İ)stek üzerine emekliye ayrilabilme bir hak olarak tanındığından, makul bir tarih belirtilmek suretiyle yapılan isteğe bağl emeklilik talepleri yönünden, ilgililerin emekli olmak istedikleri tarihten önce bu taleplerinden vazgeçebileceklerinin kabulü gerekir", Danıştay 11 D, E 2001/3220 k 2004/3925, 06.10.2004; Aynı yönde bkz Danıştay 11 D, E 2007/8864 K2008/665, 30.01.2008; Danıștay 5 D, E 1999/2302 K 1999/2444, 09.09.1999. 
gerekçesiyle idari yargı yerince iptal edilmiştir ${ }^{92}$. Bu karardan hareketle, pay satışını gerçekleştirmeye yetkili idarenin, pay satış şartlarının gerçekleştirilip gerçekleştirilmediğine ilişkin yapacağ değerlendirme ve vereceği kararın, yapılacak pay satışı işleminin hukuka uygunluğuna doğrudan etki edeceğini söylemek mümkündür.

Öte yandan, pay satış başvurusu üzerine idarece yapılacak değerlendirmenin kapsam ve içeriği, idarenin sorumluluğuna da etki edecek niteliktedir. İdarece yapılacak değerlendirmenin, pay satış dosyası içerisinde yer alan belgelerin hukuka uygunluğunu denetlemeyi de ihtiva ettiği kabul edilirse; - bir üst paragrafta bahsi geçen yargı kararında olduğu gibi - pay satış şartlarının hukuka uygun şekilde sağlanmamasına karşın, idarece başvurunun kabul edilerek payın satılması nedeniyle payı satılan malik(ler)in uğradığı/ uğrayacağı zararlardan dolayı idarenin sorumluluğu gündeme gelebilecektir. İdarece yapılacak değerlendirmenin kapsamının, Uygulama Yönetmeliğininin 15/A maddesinde yer alan bilgi ve belgelerin varlığını 'şeklen' kontrol etmekten ibaret olduğu söylenirse; pay satış şartlarının hukuka aykırı şekilde ve/ fakat şeklen sağlanmış olması ve idarenin bu denetimi gerçekleştirmiş olması nedeniyle, pay satışının gerçekleştirilmesinden idarenin sorumluluğunun bulunmadığı söylenebilecektir.

Bu iki yaklaşım tarzından ilkinin kabul edilmesi daha doğru olacaktır. Zira, pay satış işlemi, idari faaliyet neticesinde gerçekleşmektedir. Maliklerce pay satışı için gerekli olan şartların sağlanması, pay satışı için yeterli olmamaktadır. Kanun koyucu, bu şartların sağlanması neticesinde pay satışının idarece gerçekleştirilmesini öngörmüştür. İdarece pay satışının gerçekleştirilebilmesi içinse, pay satış şartlarının hukuka uygun şekilde sağlandığının idarece tespiti gerekmektedir. Bu nedenle, pay satışı için idareye yapılacak başvurunun, başvuru ekinde yer alan belgelerin içeriğini de kapsayacak şekilde idarece şartların sağlanıp sağlanmadığı yönünden değerlendirilmesi gerekmektedir.

Pay satış başvuru dosyası üzerinden yapılan incelemede; başvuruda eksiklik bulunması veya şartlarını sağlamadığına kanaat getirilmesi halinde, başvuru reddedilecektir. Bu eksikliklerin, pay satış usulünün ilerleyen aşamalarında (açık artırma aşaması gibi) fark edilmesi veya ortaya çıkması durumunda, - pay satış kararı verilip mülkiyet el değiştirene kadar - pay satış işlemleri durdurularak, başvuru yine reddedilmelidir. Ret kararı, idari davaya konu edilebilir, kesin ve yürütülebilir nitelikte bir idari işlemdir. Öte yandan, bir üst başlıkta da ifade edildiği üzere, pay satışı için yapılan başvuru

92 İstanbul BİM 6 İDD, E 2018/1159 K 2018/1019, 06.09.2018: “Olayda, dava dosyasinda bulunan bilgi ve belgelerin birlikte değerlendirilmesinden, davacının imzalamadığı iddia edilen sözleşmede yıkılan taşınmaz yerine yapılacak yeni taşınmazda 8 adet konut 2 adet işyeri yapılacağı bilgisinin yer aldığı ancak söz konusu taşınmaz için hazırlanan projede bağımsız bölüm olmayan mağaza katlarının çiziminin yapıldığı, yeni taşınmazın konut mu yoksa başka bir amaçla kullamılacak işyeri mi (alısveriş merkezi vb) olduğu hususunun belli olmadığı, kat malikleri toplantısında 157 ay kiralama karşıllğı inşaat yapım sözleşmesinin kabulüne karar verildiği ancak sözleșme içeriğinde 8 adet konut 2 adet işyeri olmak üzere 10 adet bağımsız bölüm inşa edileceği hükmünün yer aldığı, sözleşmede maliklerin arsa paylarının ve hisselerinin belirlenmeyerek boş bırakıldığı, bağımsız bölüm maliklerine hangi şartlarda bağımsız bölüm verileceği bilgisine yer verilmediği görülmektedir. Bu durumda; davacının imzalamadığı kat malikleri toplantısında kabul edilen sözleşmenin kendi içinde çelişkiler içerdiği, bu haliyle 6306 sayılı Kanun ile ilgili Yönetmeliğin amacına ve ruhuna uygun olarak maliklerin haklarının korunmasına yönelik yeterli şartlara haiz olmadığı, sözleşmede bağımsı bölüm maliklerine hangi şartlarda bağımsız bölüm verileceği bilgisine yer verilmediği gibi maliklerin arsa paylarının ve hisselerinin belirlenmeyerek boş bırakıldı̆̆ı görüldü̈̆̈̈nden, davacının Anayasa ile güvence altına alınan mülkiyet hakkının devrine neden olacak hissesinin satışına ilişkin dava konusu işlemde hukuka uyarlık bulunmadığı sonucuna varılmıştır". 
IYYUK m.10 kapsamındadır. Bu nedenle, yapılan başvurunun otuz gün içerisinde neticelendirilmemesi halinde, bu süre sonunda da başvurunun zımnen reddedildiği sonucu ortaya çıkacaktır.

İdarece yapılacak değerlendirme neticesinde, pay satışına ilişkin şartların sağlandığı sonucuna ulaşılırsa, Uygulama Yönetmeliği md.15/A f. uyarınca, satışı yapılacak payın tapu kütüğünün beyanlar hanesine, 6306 sayılı Kanun’a göre satış işlemine tabi olduğu ve satışa veya taşınmazın devrini gerektiren benzeri bir işleme tabi tutulamayacağı yönünde belirtme yapılması ilgili tapu müdürlüğünden yazılı olarak istenecektir. Böylelikle, iyiniyetli üçüncü kişilerin sicile güvenerek ${ }^{93}$ hak elde etmeleri engellenebilecektir ${ }^{94}$.

\section{BEDEL TESPITI VE SATIŞ KOMISYONUNUN BELIRLENMESI}

Satışı yapılacak arsa paylarının rayiç değerini tespit etmek ve sonrasında satış işlemini gerçekleştirmek üzere, yetkili idare bünyesinde, biri başkan ikisi üye olmak üzere en az üç kişiden oluşan Bedel Tespit Komisyonu ve Satış Komisyonu teşkil olunmaktadır. Bedel tespiti ve payın satışına ilişkin işlemler, bu komisyonlar tarafından yürütülmektedir.

Ancak mevzuatta, komisyonların üyelerinde aranacak nitelikler bakımından herhangi bir düzenleme bulunmamaktadır. $\mathrm{Bu}$ da komisyonu görevlendirecek makama, komisyonu oluşturacak kişileri belirleme konusunda oldukça geniş takdir yetkisi bahşetmektedir. Sahip olunan bu takdir yetkisinin, yürütülen faaliyetin gerekleri doğrultusunda kullanılmasına dikkat edilmelidir. Özellikle bedel tespitinin, uzmanlığı ve teknik bilgiyi gerektirdiğine şüphe yoktur. Her ne kadar öncesinde maliklerce SPK lisanslı değerlendirme kuruluşundan alınmış bir bedel tespit raporu varsa da, bu rapor, Bedel Tespit Komisyonunu bağlayıcı nitelik taşımamaktadır. Bu nedenle Bedel Tespiti Komisyonu üyelerinin, bu tespiti yapabilecek yeterliliğe sahip kişilerden teşkili, satışa esas alınacak bedelin 6306 sayılı Kanun’un öngördüğü 'rayiç bedel'i yansıtmasına ve mülkiyet hakkına doğrudan etkisi bulunmaktadır. Bu nedenle, Uygulama Yönetmeliği'nde bedel tespiti komisyonu üyelerinin niteliklerine ve görevlendirmelerine ilişkin düzenleme yapılmasının isabetli olacağı kanaatini taşımaktayız ${ }^{95}$.

\section{BEDELIN BELIRLENMESI}

Satışı yapılacak payın bedeli, 'rayiç bedel' olarak belirlenmiştir ${ }^{96}$. Rayiç bedelin kim tarafından tespit edileceği belirlenmiş olmakla birlikte; nasıl belirleneceğine ilişkin düzenleme mevzuatta yer

93 Yargitay 1 HD, E 2005/13101 K 2006/680, 06.02.2006 çerçevesinde bu yönde “[...] Bir ayni hak tapu kütüğüne yolsuz olarak tescil edilmiş ise bunu bilen veya bilmesi gereken üçüncü kişi söz konusu yolsuz tescile dayanarak yeni veya başka bir hak iktisap edemez. Ancak, tapu kütüğündeki sicile iyi niyetle dayanarak mülkiyet veya başka bir ayn, hak kazanan üçüncü kişinin bu kazanımı kütükteki sicil yolsuz olsa da korunur. Tapu kütüğündeki yolsuz tescilden sonra ikinci ve üçüncü el durumunda bulunan yeni maliklerin iyi niyeti yönünden yeterli araştırma yapılmaksızın verilen kararın bozulması gerekir. Kötü niyet iddiasının def'i olmayıp itiraz olması sebebiyle, iddia ve savunmanın genişletilmesi yasağına tabi olmaksızın her zaman ileri sürülmesi mümkündür [...]" denmektedir.

94 Aynı yönde bkz Onur Kaplan, İdare Hukuku Yönünden Afet Riski Altındaki Alanların Kentsel Dönüşüm Süreci (1. Bası, On İki Levha Yayıncılık 2017) 162.

95 Örneğin, teknik değerlendirme gerektiren riskli yapı tespitlerine karşı yapılacak itirazları değerlendirmek üzere kurulacak teknik heyetlerin teşkiline ilişkin düzenlemeye Uygulama Yönetmeliği md.9'da yer verilmiştir.

96 6306 sayılı Kanun md.6, Uygulama Yönetmeliği md.15/A/3, md.15/A/7, md.15/A/8, md.15/A/9, md.15/A/13. 
almamaktadır ${ }^{97}$. Uygulama Yönetmeliği’nin 15/A/3. maddesine göre rayiç bedel, paydaşlarca SPK’ya kayıtlı olarak faaliyet gösteren lisanslı değerleme kuruluşlarına tespit ettirilmiş olan taşınmazın değeri de gözetilerek Bedel Tespiti Komisyonunca belirlenecektir. Bir diğer ifadeyle, satışa konu edilecek payın rayiç bedeli, idarece belirlenmektedir.

Uygulamada idare bünyesinde kurulan Bedel Tespit Komisyonu’nun, payın bedelinin belirlenmesi için taşınmazın bulunduğu alana görevlileri göndererek, yerinde inceleme/değerleme yaptığı bilinmektedir. Buna karşın yine uygulamada SPK lisanslı değerleme kuruluşu tarafından tespit edilen değer ile Bedel Tespit Komisyonu tarafından tespit edilen değer arasında çok ufak farklllıklar olduğu görülmektedir. Uygulama Yönetmeliğìnde de rayiç değerin SPK lisanslı değerleme kuruluşunun raporu "gözetilerek" tespit edileceği ifade edilerek, adeta bu raporun esas alınması gerektiği telkin edilmektedir. Ancak maliklerce alınan değerleme raporu, rayiç bedel tespiti yapacak idare açısından bağlayıcı değildir.

İdare tarafından belirlenen rayiç bedel tespitine ilişkin kararın, kesin ve yürütülebilir nitelikte bir işlem olup olmadığı üzerinde ise ayrıca durulması gerekmektedir. Bilindiği üzere, idari yargı yerlerinde dava konusu edilen idari işlemlerin kesin ve yürütülebilir işlem olması zorunludur. Kesin ve yürütülebilir nitelikte olmayan işlemlere karşı açılan davaların ise reddine karar verilmektedir ${ }^{98}$. "Kesin ve yürütülmesi zorunlu, idari davaya konu edilebilecek işlemler, idarenin kamu gücüne dayanarak, tek yanlı irade beyanıla tesis ettikleri, hukuk düzeninde değişiklik yapan başka bir deyişle ilgililerin hukukunu etkileyen işlemlerdir ${ }^{299}$.

Rayiç bedel tespitine ilişkin karar, başkaca bir makamın değerlendirme veya onayına ihtiyaç duymaksızın, idarece belirlenen tarihte gerçekleştirilecek pay satışına esas alınmakta ve satılacak payın asgari bedelini göstermektedir. Payın, ilk ihalede satılmaması halinde, pay satışı gerçekleşene kadar satış işlemi tekrar edilmekte; ancak yeni bir rayiç bedel hesabı yapılmamaktadır. İdarece belirlenen bedelin, rayiç bedelden fazla belirlenmesi, ilk artırımda payı satın almak isteyen paydaşların; düşük belirlenmesi ise, payı satılan malikin hukuki durumuna olumsuz etki etmektedir. Şu hâlde, Bedel Tespiti Komisyonunca belirlenen ve maliklere tebliğ edilen rayiç bedel tespiti kararının hem payı satılacak malik hem de payı satın alacaklar açısından hukuki durumu etkilediği; bu yönüyle kesin ve yürütülebilir nitelik taşıdığı söylenebilecektir.

\section{SATIŞ TARIHININ BELIRLENMESI VE PAYDAŞLARA TEBLIGAT YAPILMASI}

Rayiç bedel tespit edildikten sonra idare, satışın yapılacağı yeri ve zamanı, 2/3 çoğunlukla anlaşan paydaşlara ve müteahhit firmanın adreslerine taahhütlü posta yoluyla veya TK’ya göre tebliğ edecektir. Uygulama Yönetmeliği’nin 15/A/4. maddesinde, "(s)atışıın yapılacağı yer ve zaman satışı izlemek üzere arsa payı satılacak maliklere de bildirilir. Ancak, arsa payı satılacak maliklere tebligat yapılamamış olması veya bu maliklerin satışa izleyici olarak katılmaması satışın geçerliliğine etki etmez ve giyaplarında yapılan satış işlemi geçerli olur" hükmü yer almaktadır.

97 Uygulama alanlarında bedel tespitine ilişkin kurallar için $\boldsymbol{b} \boldsymbol{k} z$ Uygulama Yönetmeliği md.12.

98 Bu yönde bir örnek için $\boldsymbol{b k z}$ Danıştay 12 İDD, E 2004/4077 K 2005/1353, 13.04.2005.

99 Danıştay 14 İDD, E 2015/11430 K 2018/396, 06.02.2018 Danıştay Dergisi (2018) (148) 382-384. 
Uygulama Yönetmeliğinnin bu hükmü, kendi içerisinde çelişkili görünmektedir. Satışın yapılacağı yer ve zamanın, satışı izlemek üzere payı satılacak maliklere de bildirileceği söylendikten sonra, payı satılacak paydaşlara tebligat yapılamamış olmasının satışın geçerliliğine etki etmeyeceği ifade edilmiştir.

Uygulama Yönetmeliğine bakıldığında, 'bildirim' ve 'tebligat' ifadelerine de ayrı ayrı yer verildiği görülmektedir. Yönetmeliğin lafzından hareketle, idarece yapılması zorunlu olanın 'bildirim' olduğu ve her türlü vasita (whatsapp, sms, e-posta vb.) kullanılarak gerçekleştirilebileceği; yapılması zorunlu olmayanın ise 'tebligat' olduğu düşünülebilecektir. Ancak, payı satılacak maliklere tebligat dışındaki vasitalarla 'bildirim’in yapıldığı ve muhatabına ulaştığının belirlenmesi oldukça zordur. $\mathrm{Bu}$ nedenle, payı satılacak maliklere idarece yapılacak 'bildirim'in, esas itibariyle tebligat yoluyla yapılması gerektiği; bu tebligat yapılmaksızın gerçekleştirilecek satıss işleminin hukuka uygun bir satış olmayacağı söylenebilir ${ }^{100}$.

Nitekim uygulamada idareler satış kararının muhalif paydaşlara da tebliğ edilmesini sağlamakta ve buna önem göstermektedir. Ayrıca, satış tarihinin - paydaşların şehir içi / şehir dışında ikamet etme durumlarına göre - muhtemel tebligat süreleri dikkate alınarak saptandığı görülmektedir. Böylece, payı satılacak olması sebebiyle mülkiyet hakkına müdahale edilen maliklere, satışın hukuka uygun şekilde gerçekleștirilip gerçekleştirilmediğini gözlemleme; satış sırasında herhangi bir hukuka aykırı iş veya işlem gördügünde ise hukuki yollara başvurma imkânı sağlanmaktadır. Satış kararın paydaşlara tebliği ile birlikte yazılı bildirim yapılmış sayılacak [Anayasa md.125 f.3/6306 sayılı Kanun md.6/9] ve dava açma süresi işlemeye başlayacaktır.

\section{B. SATIŞ AŞAMASI}

Satışa dair hazırlık aşaması tamamlandıktan sonra sırada satış aşaması vardır. Satışın ne şekilde yapılacağı Uygulama Yönetmeliğỉnin 15/A. maddesinde belirtilmiştir.

\section{SATIŞA KATILACAKLARIN TESPITI}

İdarece belirlenen ve maliklere tebliğ edilen satışın yapılacağı 1 yer ve zamanda, satışa katılma hakkı olanlar hazır bulunmak zorundadırlar. Yapılacak ilk satışa en az 2/3 çoğunluk ile anlaşan paydaşlar dışında herhangi biri katılamayacaktır. Satışa katılanların kimliği bu doğrultuda Satış Komisyonu tarafından kontrol edilerek bir tutanak ile kayıt altına alınmaktadır. Bu aşamada, satışa katılamayacak kişilerin varlığı halinde, durum tutanak altına alınarak; bu kişilerin satışa katılmasının

100 Ancak uygulamada payı satışa konu edilecek maliklerin, satışı geciktirmek adına tebligat adreslerini yurt dışına taşıdıkları görülmektedir. Böyle bir durumda, idarece yapılacak bildirimin hukuka uygunluğu konusunda yapılacak değerlendirmede, adresin taşınma zamanı ile payı satışa konu edilecek malikin 'dürüstlük kuralı' çerçevesinde hareket edip etmediği göz önünde bulundurularak, elverişli araçlarla yapılacak 'bildirim’in yeterli kabul edilmesinin, 6306 sayllı Kanun'un amacı ve Uygulama Yönetmeliği’nin lafzına uygun olduğu kabul edilebilecektir. Fakat yukarıda da ifade edildiği üzere, böyle bir durumda payı satılacak maliklere ‘bildirim’in yapıldığının ortaya konulması bir başka zorluk olarak karşımıza çıkacaktır. 
önüne geçilmelidir. Aksi takdirde, satış işlemi hukuka aykırı olacaktır. Nitekim Danıştay, en az 2/3 çoğunlukla anlaşma sağlayan maliklerle kat karşllığı inşaat sözleşmesi imzalayan yüklenicinin ${ }^{101}$ ve $2 / 3$ çoğunluk ile anlaşan maliklerden birinin payını, anlaşma sonrasında ve/fakat pay satışı öncesinde satın alan kişinin ${ }^{102}$, paydaşlara yapılacak ilk satışa katılamayacaklarını ifade etmiş ve bu kişilere yapılan satışı iptal etmiştir. İdarece belirlenen yer ve zamanda hazır bulunmayan maliklerin ilk satışa katılma hakları düşecektir.

\section{AÇIK ARTIRMANIN YAPILMASI}

Katılımcı durumunu gösteren tutanağın tanziminden sonra Satış Komisyonu Başkanınca, satışa çıkarılan arsa paylarına ilişkin bilgiler satışa katılanlara bildirilir ve satış işlemi başlatılır. Satış Komisyon Başkanı, rayiç bedelin altında olmamak üzere satışa katılan paydaşlardan, sözlü olarak pey sürmelerini ister. Sürülen peyler arttırma tutanağına yazılarak, karşısı pey sahibi tarafından imzalanır. Arttırma işlemine devam etmeyecek katılımcıların keyfiyeti, arttırma tutanağına yazması ve imzalaması zorunludur. Satışa tek bir katılımcının dahil olması halinde, rayiç değerinden az olmamak üzere bu katılımcının vereceği teklif geçerli kabul edilir.

\section{BEDELIN ÖDENMESI VE TAPUYA TESCIL}

Yapılan satış işlemi sonunda, tespit edilen rayiç bedelden az olmamak üzere, en yüksek bedeli teklif eden katılımcıya satış yapılması karara bağlanarak, bu katılımcıdan satış bedelini yedi gün içerisinde banka nezdinde açtırılacak vadeli hesaba yatırması istenir. Bu süre içerisinde satı̧̧ bedeli yatırılmaz ise, malikin satın alma hakkı düşecektir. Belirlenen sürede satış bedelinin yatırılmasından sonra, satış işlemi, tapuda yeni paydaş adına tescil yapılmak üzere, ilgili tapu müdürlüğüne bildirilir. Tapu müdürlüğünce tescil işlemi tamamlandıktan sonra, yeni tapu

101 Danıştay 14 D, E 2015/8136 K 2017/3582, 30.05.2017: “...(H)isse satışının gerçekleştiği açık artırmaya sadece üçte iki çoğunluk ile anlaşan mülkiyet hakkına sahip paydaşların katılabileceği hükme bağlandığından, taşınmaz satış vaadi ve kat karşıllğ̆ inşaat sözleşmesiyle yapılacak işi üstlenen yüklenici şirketin bu paydaşlar adına açık artırmaya katılarak satışı yapılan hisseleri satın almasıla sonuçlanan satışa ilişkin dava konusu işlemde hukuka uyarlık, Mahkemece verilen davanın reddi yolundaki kararda da hukuki isabet bulunmamaktadır".

102 Danıştay 14 D, E 2016/7079 K 2017/436, 01.02.2017:“Uyuşmazlikta; yukarıda belirtilen mevzuat uyarınca toplanılarak riskli yapının bulunduğu parselde yapılacak uygulamalara ilişkin alınan 02/07/2014 tarihli kararın altında imzası bulunan paydaşlar arasında Şükrü Sincar’n olmadığı, aksine $2 / 3$ çoğunluğu sağlayan paydaşların yeni yapılacak uygulama için müteahhitlik firması Ş.S. İnşaat ile anlaştığı görülmüş, taşınmaza ilişkin tapu kayıtlarının incelenmesinden ise paydaşlardan İ. B.’nın payının bir kısmını 16.12.2015 tarihinde Ș.S.'a satmak suretiyle devrettiği ve Ș. S.in bunun üzerine 07.01.2016 günü açık artırma suretiyle yapılan ihaleye katılımının sağlandı̆̆ı ve ihale sonucunda davacıların paylarının müteahhit Ş. S.á satışının yapıldığı görülmüştür.

Öte yandan, paydaşlardan tarafindan, 16.12.2015 tarihinde yapılan tapu tescil işleminin iptal edilerek (Şuf'a hakkı dolayısıyla) satışa konu payın tapuda kendi adına tescilinin sağlanması istemiyle müteahhit Şükrü Sincar’a karşı açılan davada, [...] 3.Asliye Hukuk Mahkemesinin 06/10/2016 tarih, E:2015/709, K:2016/452 sayıl kararlyla, davanin kabul edildiği anlaşılmıştır.

Bu durumda; 2/3 çoğunluk ile anlaşan paydaşlar arasında olmadığı, 16.12.2015 tarihinde satın aldı̆̆ı pay nedeniyle ihaleye katıldiğı, ancak yukarıda belirtilen verilen karar üzerine paydaş sıfatın kaybettiği sabit olan müteahhit Ș.S.a 07.01.2016 tarihinde yapılan açık artırma sonucunda yapılan dava konusu satış işleminde hukuka uyarlı, temyize konu İdare Mahkemesi kararında ise hukuki isabet bulunmamaktadr". 
kaydı idareye gönderilir ve idarece durum payı satılan ilgiliye bildirilir. Payı satılan malik, açık artırmaya katılmamışsa, pay satışını bu bildirimle öğrenmekte; dava açma süresi bu anda başlamaktadır.

Pay satış süreci, pay satış kararı verilmesiyle birlikte tamamlanmakta; pay satış bedelinin ödenmesi ve tescille mülkiyet yeni malike devrolunmaktadır. Bu noktadan sonra, aynı taşınmaza ilişkin pay satış usulünün tekrar işletilmesine olanak bulunmamaktadır ${ }^{103}$.

En yüksek bedeli teklif eden malikin, belirlenen süre içerisinde satış bedelini yatırmaması halinde ise, pey süren diğer katılımcılara sırasıyla bildirimde bulunulur ve satış bedelini yatıran katılımcıya satış yapılır. Satışa tek bir katılımcının dahil olması halinde, rayiç değerinden az olmamak üzere bu katılımcının vereceği teklif geçerli kabul edilir. Satış bedelinin yatırılmasından sonra, satış işlemi, tapuda yeni paydaş adına tescil yapılmak üzere, ilgili tapu müdürlügüne bildirilir. Tapu müdürlüğünce tescil işlemi tamamlandıktan sonra, yeni tapu kaydı idareye gönderilir ve idarece durum payı satılan ilgiliye bildirilir.

\section{SATIŞIN TEKRARLANMASI VE ÜÇÜNCÜ KIŞILERIN KATILIMI}

İlk satış işleminde satılacak hissenin anlaşma sağlayan paydaşlarca alınmak istenmemesi durumunda yeniden yapılacak satış işleminin yeri ve hangi tarih ve saatte yapılacağı belirlenerek tutanağa bağlanır. Bu tutanağın bir örneği satış için huzurda bulunan paydaşlara verilir. Satışı yapılacak hisseye ilişkin bilgiler ile satışın yapılacağı yer, tarih ve saat idare yayın araçlarıyla ve ilan panosuna asılacak yazı ile ilan edilir.

103 Ankara BİM 5. İDD, E 2019/1009 K 2020/206, 05.03.2020: “Uyuşmazlık konusu olayda; davacının Ankara İli A3 İlçesi, A1 Mah. 23521 Ada ve 4 numaralı parselde yer alan taşınmazın hissedarı olduğu, anılan taşınmazın 6306 sayıl Afet Riski Altındaki Alanların Dönüştürülmesi Hakkında Kanun kapsamında riskli yapı olarak tespitinin yapıldığı, bu kararın yargı sürecinden de geçerek kesinleştiği, sonrasında maliklerin üçte iki çoğunluğunun yeniden yapım konusunda anlaştığ ve Altındağ 3. Noterliğinin 24.12.2012 tarih ve 28736 yevmiye no lu düzenleme şeklinde gayrimenkul satış vaadi ve kat karşılığı inşaat sözleşmesi düzenledikleri, karara katılmayan malik K4'ye ait hissenin satışının 15.10.2015 tarihinde gerçekleştirildiği, [...] sonrasında satış işleminin tapuda tescil edildiği, daha sonra maliklerden birisi tarafindan A3 Belediye Başkanlı̆̆ı'na verilen dilekçe ile söz konusu ada parsele ilişkin imar durumu sorulması üzerine ilgili belediyece adı geçen malike "imar durumunda değişiklikler olduğu ve özellikle bina yüksekliğin serbest olarak değiştiği” yönünde cevap verilmesi üzerine, yapılan imar planı değişikliği sebebiyle sözleşmenin yenilenmesi gerekliliği kapsamında maliklerin üçte $i k i$ çoğunluğunun yeniden inşaat yapımı konusunda 2. kez anlaştığı ve müteahhitle yeni bir gayrimenkul satış vaadi ve kat karşılığı inşaat sözleşmesi düzenledikleri, davacının ilk sözleşmeyi imzaladiğı ancak dava konusu satış işlemine konu olan ikinci sözleşmeyi imzalamadı̆̆ı, öte yandan Altındağ 3. Noterliğinin 24.12.2012 tarih ve 28736 yevmiye no lu düzenleme şeklinde gayrimenkul satış vaadi ve kat karşılı̆̆ inşaat sözleşmesinin ayakta olduğu anlaşılmaktadır. Olayda, 6306 sayılı Yasa ve Uygulama yönetmeliği kapsamında riskli yapı olduğu belirlenen taşınmazların yıkılacă̆l, yıkım sonrasında arsa haline dönüşen taşınmazın parsel malikleri tarafından değerlendirilmesinin esas olduğu, bu kapsamda taşınmazda yeniden bina yaptırılması hususunda parsel maliklerinin en üz üçte iki çoğunluk ile karar verebilecekleri, karara katılmayan hisse sahiplerine karara katılmaları yönünde 15 gün süre verileceği, aksi takdirde arsa paylarının değeri tespit edilerek diğer arsa sahiplerine açık arttırma yolu ile satılacağı açık olmakla birlikte bu sürecin bir kez mümkün olduğu, yapının imar durumunda sonradan meydana gelen değişiklik nedeniyle bir kısım malik ile müteahhit arasında imzalanan yeni sözleşmenin özel hukuk sözleşmesi niteliğinde olduğu ve artık 6306 sayılı Yasa ve Uygulama yönetmeliğindeki hükümlerin uygulanamayacağı, yeni sözleşmeyi imzalamayarak üçte birlik kısımda kalan maliklerin hisselerinin 6306 sayılı Kanun kapsamında idarece satışa çıkarılamayacă̆ı, dolayısıla ikinci sözleşmeyi imzalamayan davacının hissesinin 2/3 kararı oluşturan maliklere satışına dair dava konusu işlemde hukuka ve mevzuata uyarlık bulunmadığı sonucuna varılmıştır”. 
Tekrar yapılacak satış işlemlerine yine en az $2 / 3$ çoğunluk ile anlaşan paydaşlar ve satıştan önce 2/3 çoğunluk ile alınan kararı kabul edeceklerini ve 2/3 çoğunluk ile alınan karar doğrultusunda yapılan sözleşmeyi ve yapılacak uygulamanın gerektirdiği diğer belgeleri imzalayacaklarını yazılı olarak beyan eden ve satışı yapılacak arsa payının rayiç değerinin \%10’u oranında nakit teminat veren üçüncü kişiler katılabilir.

İkinci satışa katılmak isteyen üçüncü kişilerin verecekleri nakit teminatın ilgili muhasebe birimine yatırılması zorunludur. Yapılacak satış neticesinde satış ihalesi üzerinde kalmayanların teminatları ise hemen geri verilir. Satış ihalesi üzerinde kalan üçüncü şahsın teminatı ise satış bedelinin yatırılmasından ve tapuda yeni paydaş adına tescil işleminden sonra, bu şahsın yedi gün içinde $2 / 3$ çoğunluk ile alınan karar doğrultusunda yapılan sözleşmeyi ve yapılacak uygulamanın gerektirdiği diğer belgeleri anlaşan diğer malikler gibi şartsız ve şerhsiz olarak imzalayarak idareye vermesinden sonra iade edilir. Eğer bu üçüncü kişi satış bedelini yatırmaz ise teminatı Hazine’ye gelir kaydedilir ve Uygulama Yönetmeliği md.15/A/8 uyarınca yeniden satış yapılır. Dolayısıyla, açık artırmada payı satan alan yeni paydaşın karara katılması için Uygulama Yönetmeliği birtakım zorlamalar/teşvikler geliştirmiştir.

Satış bu sefer de gerçekleşmez ise satış gerçekleşinceye kadar her satış işleminin sonunda yapılacak diğer satışın yeri, tarihi ve saati Uygulama Yönetmeliği’nin 15/A/12.maddesine göre belirlenerek ilan edilir.

\section{PAY SATIŞININ SONUÇLARI}

Payı satışının gerçekleşmesiyle mülkiyet el değiştirmekle beraber, payı satışa konu edilen malikin payı dolayısıyla sahip olduğu yükümlülükler sonlanmamaktadır. Kanun koyucu, pay satışı sonucunda, eski malikin payı üzerindeki mükellefiyetlerine ilişkin düzenleme getirmiştir. Aşağıda, pay satışı sonucunda ortaya çıkan bu yükümlülükler üzerinde durulacaktır.

\section{A. BEDELE BLOKE KONMASI}

Satışı yapılacak payın üzerinde ipotek, ihtiyati haciz, haciz, intifa hakkı, oturma hakkı gibi hakların bulunması halinde ${ }^{104}$, satışın akabinde, satış bedelinin yatırıldığı banka hesabına, malike ödeme yapılmaması için Satış Komisyonu tarafından bloke bildiriminde bulunulur ve bu doğrultuda hesaba bloke konur ${ }^{105}$. Eski paydaş/borçlu hesabına pay satışından gelen bedelin yattığı, Uygulama Yönetmeliği'nin 15/A/5. maddesi doğrultusunda ipotek, haciz ve intifa hakkı gibi hakların alacaklısına veya ilgili icra müdürlügüne veya mahkemeye bildirilir. Satış bedelinin, belirtilen hak sahiplerine ödenmesi ile ilgili iş ve işlemler ise ilgili mevzuata göre ve ilgililerince yürütülmektedir.

1046306 sayılı Kanun md.6 f.1 uyarınca taşınmazların sicilinde bulunan taşınmazın niteliği, ayni ve şahsi haklar ile temlik hakkını kısıtlayan veya yasaklayan her türlü şerh, hisseler üzerinde devam eder.

Uygulama Yönetmeliği md.15/A f.5 uyarınca satışı yapılacak payın üzerinde ipotek, ihtiyati haciz, haciz ve intifa hakkı gibi hakların bulunması satış işlemine engel teşkil etmez.

105 Özmen / Şengül (n 26) 444. 
Alacaklılar tatmin edildikten sonra tapu kaydındaki haklar ve şerhler İdarenin talebi üzerine ilgili tapu müdürlüğ̈ünce resen terkin edilmektedir.

\section{B. HAKLARIN BEDEL ÜZERINDE DEVAM ETMESi}

6306 sayılı Kanun ve Uygulama Yönetmeliği’nde satışı yapılacak payın üzerinde ipotek, ihtiyati haciz, haciz ve intifa hakkı gibi hakların bulunmasının satış işlemine engel teşkil etmeyeceği; belirtilen hakların satış sonrasında satış bedeli üzerinde devam edeceği düzenlenmiştir ${ }^{106}$. Görüleceği üzere, satışı yapılacak payın üzerindeki haklar numerus clausus sayılmamış; "[...] intifa hakkı gibi [...]" denerek payın üzerinde bulunabilecek bütün haklar maddenin kapsamına alınmıştır. Ne var ki akla, pay üzerindeki - örneğin - oturma hakkının satış bedeli üzerinde nasıl devam edeceği sorusu gelmektedir ${ }^{107}$.

Kanaatimizce kanun koyucunun bu konudaki düzenlemesinin anlaşılması için, TMK’nın “İntifa hakkı sahibinin durumu” başlıklı 700. maddesinin incelenmesi gerekmektedir ${ }^{108}$. Söz konusu hükümde satış yoluyla paylaşmada intifa hakkının, buna ilişkin paya düşecek bedel üzerinde devam edeceği öngörülmüştür ${ }^{109}$. Nasıl ki TMK md.700'de intifa borçlusu-yükümlüsü olmayan paydaşların korunması amaçlanmışsa, 6306 sayılı Kanun ve Uygulama Yönetmeliği'nin ilgili maddelerinde de "hakların satış sonrasında satış bedeli üzerinde devam edeceğinin” düzenlenmesinin, payın satışının önündeki engelleri kaldırmak olduğu düşünülmektedir. Böylece, muhalif paydaş ile üçüncü kişi arasında kurulabilecek muvazaalı anlaşmanın etkisini göstermesi engellenebilecek; üzerinde şerh/ hak bulunan bir pay satışının zorlukları giderilebilecek ve pay üzerindeki haklardan, bunların doğmasından hiçbir sorumluluğu olmayan üçüncü kişilerin etkilenmesinin önüne geçilebilecektir.

\section{PAY SATIŞINA KARŞI BAŞVURU YOLLARI}

6306 sayılı Kanun’un 6/9.maddesine göre, “Bu Kanun uyarınca tesis edilen idari işlemlere karşı teblĭ̆ tarihinden itibaren otuz gün içinde 6/1/1982 tarihli ve 2577 sayılı İdari Yargılama Usulü Kanunu

106 Uygulama Yönetmeliği md.15 f.10 uyarınca 6306 sayılı Kanun kapsamındaki yapıların yıktırılmasından sonra bu taşınmazların sicilinde bulunan ayni ve şahsi haklar ile temlik hakkını kısıtlayan veya yasaklayan her türlü şerh, hisseler üzerinde devam eder.

6306 sayılı Kanun md.6 f.1'de yer alan "hisseler üzerinde devam eder" şeklindeki düzenlemenin, ancak binanın yeniden yaptırılması durumunda anlam ifade edeceği yönünde $\quad \boldsymbol{b} \boldsymbol{k} z$ İnal (n 58) 121.

107 Sınırlı ayni hak ve şerhlerin paylı mülkiyet payında varlıklarını mutlak bir şekilde sürdürmelerinin mümkün olmadığı, ancak nitelikleri ile bağdaştığı ölçüde bunun söz konusu olabileceği yönünde $\boldsymbol{b} \boldsymbol{k} z$ Özmen / Şengül (n 26) $214-215$.

108 Bu hususta $\boldsymbol{b} \boldsymbol{k z}$ Abdulkadir Arpacı, 'Müşterek Mülkiyette Pay Üzerinde İntifa Hakkı Kurulmasının Diğer Paydaşlara Etkisi’ Marmara Üniversitesi Hukuk Fakültesi Hukuk Araştırmaları Dergisi (2014) 20(1) 981, 985.

109 Satışın paya dayalı intifa ile yükümlü olarak yapılması halinde, kural olarak ihale bedelinin bu nedenle düşük satış rakamına yol açacağının hayatın olağan akışına ve günlük yaşam tecrübelerinin gereği olacağı ve intifa hakkının yükümlüsü olmayan ve bu konuda hiçbir şekilde irade beyanı bulunmayan paydaşların, pay üzerinde kurumuş bir intifa hakkının getirdiği külfete katlanmalarının hiçbir mantıkla izah edilemeyeceği yönünde $\boldsymbol{b} \boldsymbol{k} \boldsymbol{z}$ Etem Saba Özmen ve Melek Bilgin Yüce, 'MK “Madde 700” Hükmünce Pay Üzerindeki İntifa Haklarının Paylı Halin Giderilmesi Davalarına İlişkin Hukuki Sonuçlar’ İstanbul Barosu Dergisi (2007) 81(3) 949, 965; Yargitay İBGK E 1/ K 3, 14.03.1960; Yargitay 14 HD, E 2014/12215 K 2015/4089, 14.04.2015; E 2014/13943 K 2015/9164, 19.10.2015 ve E 2017/3490 K 2018/1061, 15.02.2018. 
uyarınca dava açılabilir”. Görüldüğü üzere kanun koyucu, 6306 sayılı Kanun kapsamında tesis edilen idari işlemlere karşı yargı yolunu düzenlemiş; süresini ise idari yargıda genel dava açma süresi olan altmış gün yerine, otuz güz olarak belirlemiştir. Bu hükümden hareketle öncelikle vurgulanması gereken husus, dava konusu edilebilecek olan işlemler, 6306 sayılı Kanun'dan kaynaklı 'idari işlem'lerdir. Bir diğer ifadeyle, kesin ve yürütülebilir nitelikte olan işlemler dava konusu edilebilecektir. Aynı sonuca İYUK'tan hareketle de ulaşmak mümkündür. Bu durumda pay satış usulü kapsamında idarece gerçekleştirilen, pay satış başvurusunun reddi, bedel tespiti, satış ilanı ve pay satışı gibi kararların idari yargıda dava konusu edilebileceğini söylemek mümkündür.

Bu hükümden çıkan bir diğer sonuç ise, 6306 sayılı Kanun kapsamında tesis edilen ve/fakat kesin ve yürütülebilir nitelikte olmayan - bedel tespit komisyonunun belirlenmesi gibi - işlemlere karşı herhangi bir başvuru yolu olmadığıdır. Bu işlemlerin hukuka uygunluğu, - maliklerce, pay satışı şartlarının sağlanmasına yönelik tesis edilen iş ve işlemlerinde olduğu gibi ${ }^{110}$ - ancak dava konusu olabilecek idari işlemlerle birlikte denetlenebilecektir.

Yine bu hükümden hareketle akla gelen bir diğer soru da, 6306 sayılı Kanun uyarınca tesis edilen idari işlemlere karşı otuz gün içinde dava açılabileceğinin açıkça düzenlenmesinin, bu işlemlere karşı idari başvuru yolunun kapatıldığı anlamına mı geldiğidir. Bir diğer ifadeyle, bu düzenleme, IYYUK m.11'de düzenlenen itiraz yolunu dışlamakta mıdır, yoksa IYYUK'ta gösterilen genel dava açma süresinden farklı bir dava açma süresi göstermek için mi ihdas edilmiştir? Bu yorumlardan ikincisinin amaçlandığını söylemek mümkündür. Zira mevzuatta, idari başvuru yoluna gidilemeyeceğine ilişkin açık bir yasak bulunmadığı gibi111; bu kararların 'kesin' olduğuna yönelik bir düzenleme de yer almamaktadır. Bu nedenle 6306 sayılı Kanun’un 6/9.maddesinin idari başvuru yollarını dışladığını söylemek mümkün değildir. Şu hâlde, pay satışına ilişkin işlemlere karşı hukuki başvuru yolları, idari başvuru yolu ve yargısal başvuru yolu olarak iki ayrı başlıkta ele alınmalıdır.

\section{A. IDARI BAȘVURU YOLU}

Pay satış usulü kapsamında gerçekleştirilen idari işlemlere karşı mevzuatta özel bir başvuru yolu öngörülmediği gibi; bu işlemlere karşı idari başvuru yapılmasını engelleyen bir hükümde bulunmamaktadır. İYUK md.1l'e göre "(i)lgililer tarafindan idari dava açılmadan önce, idari işlemin kaldırılması, geri alınması, değiştirilmesi veya yeni bir işlem yapılması üst makamdan, üst

110 Maliklerce tesis edilen işlemlerin, doğrudan idari yargıda dava konusu edilmesine olanak bulunmamaktadır. Ancak, bu iş ve işlemlerin hukuka uygunluğu/aykırılı̆̆ı, pay satış usulü kapsamında tesis edilen idari işlemlerin sıhhatine doğrudan etki etmektedir. Ayrıca, idarece pay satı̧sı şartlarının sağlanıp sağlanmadığı satış öncesinde denetlenmektedir ( $\mathrm{Bu}$ hususta ayrıca $\boldsymbol{b} \boldsymbol{k z}$ "Başvurunun Değerlendirilmesi ve Tapu Kütüğüne Şerh Verilmesi" başlığı.). Bu nedenle, maliklerce pay satış şartlarının sağlanmasına yönelik olarak tesis edilen hukuka aykırı nitelikteki işlemlerin, idari yargıda dava konusu edilebilir işlemlerle birlikte yargı denetimine tabi tutulabileceğini söylemek yanlış olmayacaktır. Bu husustaki bir karar için bkz İstanbul BİM 6 İDD, E 2018/1159 K 2018/1019, 06.09.2018.

111 Kanun koyucu, "16/5/2012 tarihli ve 6306 sayll Afet Riski Altındaki Alanların Dönüştürülmesi Hakkında Kanun uyarınca alınan Cumhurbaşkanı kararları"nı IYYU md.20/A/1'de saymak suretiyle ivedi yargılama usulü kapsamına almış ve 6306 sayılı Kanun kapsamında yer alan bu idari işlemler için itiraz yolunu kapamıştır. Zira, aynı maddenin 2.fikrasında "İvedi yargılama usulünde [...] Bu Kanunun 11 inci maddesi hükümleri uygulanmaz" hükmü yer almaktadır. 
makam yoksa işlemi yapmış olan makamdan, idari dava açma süresi içinde istenebilir. Bu başvurma, işlemeye başlamış olan idari dava açma süresini durdurur.” Buna göre, pay satış usulü kapsamında gerçekleştirilen idari işlemlerin hukuka aykırı şekilde tesis edildiğini düşünen malik, bu işlemlerin değiştirilmesi, kaldırılması veya geri alınması amacıyla üst makama başvurabilecektir. Bu başvuru, ihtiyari niteliktedir.

Buradaki üst makam işlemi tesis eden idareye göre değişkenlik gösterebilecektir. Uygulama Yönetmeliği’ne göre pay satışına ilişkin işlemler, Müdürlükçe ${ }^{112}$ veya Bakanlıkça yetki devri yapılması durumunda İdare ${ }^{113}$ tarafından gerçekleștirilebilmektedir. Buna göre idari işlemlerin, Altyapı ve Kentsel Dönüşüm Müdürlügü̉nce gerçekleştirilmesi halinde, Altyapı ve Kentsel Dönüşüm Hizmetleri Genel Müdürlüğüne; Çevre ve Şehircilik İl Müdürlüğü’nce gerçekleştirilmesi halinde Valiliğe; belediye veya büyükşehir belediyesi veya il özel idarelerince gerçekleştirilmesi halinde ise üst makam bulunmaması nedeniyle bu idarelere itiraz yapılabilecektir. İtirazın doğru makama yapılması, işlemeye başlayan dava açma süresini durdurması açısından önemli olmakla beraber, itirazın yapılması pay satışına ilişkin işlemleri durdurmayacaktır. İtirazın açık veya zımnen reddi halinde ise dava yoluna gidilmesi mümkündür.

Bu noktada üzerinde durulması gereken bir diğer husus ise, itirazın ne süre içerisinde yapılacağıdır. 6306 sayılı Kanun'un 6/9.maddesinde, 6306 sayılı Kanun kapsamında tesis edilen idari işlemlere karşı dava açma süresinin otuz gün olarak belirlendiği yukarıda ifade edilmişti. İYUK md.11'de, üst makama başvurunun, “[...] idari dava açma süresi içinde” yapılabileceği düzenlenmiştir. Bu cümleden olmak üzere, 6306 sayılı Kanun kapsamında tesis edilen idari işlemlere karşı üst makama başvuru yoluna gidilmek istenilmesi halinde, bu başvurunun otuz gün içerisinde yapılması gerekecektir.

\section{B. YARGISAL BAŞVURU YOLU}

Pay satışı usulü kapsamında gerçekleştirilen idari işlemlere karşı otuz gün içinde idari yargı yoluna gidilebileceği Kanun'da açıkça düzenlenmiştir. 6306 sayılı Kanun’un 6/9.maddesinde bu sürenin "tebliğ tarihinden itibaren” itibaren başlayacağı da hüküm altına alınmıştır. Aslında bu ifade, "(i)dari işlemlere karşı açılacak davalarda süre, yazılı bildirim tarihinden başlar” [Anayasa md.125/3] şeklindeki Anayasa hükmünün bir tezahürüdür. Dolayısıyla, pay satış usulü kapsamında gerçekleştirilen idari işlemler için öngörülen otuz günlük dava açma süresi, bu işlemlerin yazılı bildirimiyle başlayacaktır.

Uygulama Yönetmeliği'nin 15/A/10.maddesine göre, “(s)atış bedelinin yatırılmasından sonra, satış işlemi, tapuda yeni malik adına tescil yapılmak üzere, ilgili tapu müdürlüğüne bildirilir. Tapu müdürlüğ̈̈nce tescil işlemi tamamlandıktan sonra, yeni tapu kaydı Müdürlüğe veya İdareye

112 Uygulama Yönetmeliği, md.3/1: “Bu Yönetmelikte geçen; d)Müdürlük: Altyapı ve Kentsel Dönüşüm Müdürlüğü olan illerde bu Müdürlüğü, diğer illerde ise Çevre ve Şehircilik Ill Müdürlüğünü [...] ifade eder".

113 Uygulama Yönetmeliği, md.3/1: “Bu Yönetmelikte geçen;

b)İdare: Belediye ve mücavir alan sınırları içinde belediyeleri, bu sınırlar dışında il özel idarelerini, büyükşehirlerde büyükşehir belediyelerini, Bakanlık tarafından yetkilendirilmesi hâlinde büyükşehir belediyesi sınırları içindeki ilçe belediyelerini, ifade eder". 
gönderilir ve Müdürlük veya İdarece durum payı satılan ilgiliye bildirilir”. Görüldüğü üzere, 6306 sayılı Kanun'un 6/9.maddesi uyarınca dava açma süresinin başlangıcı olarak kabul edilen yazılı bildirim, pay satış işlemi açısından "tapu müdürlü̈̆ünce tescil işlemi tamamlandiktan sonra" gerçekleştirilmekte; dava açma süresi de bu andan itibaren başlamaktadır. Ancak payı satışa konu edilen malikin, pay satış kararını tebliğden önce öğrenmesi halinde ${ }^{114}$, bu karara karşı dava açabilmesi mümkündür ${ }^{115}$.

Bu noktada üzerinde durulması gereken bir diğer husus ise, pay satış başvurusuyla başlayan satış usulü içerisinde tesis edilen idari işlemlerin ayrı ayrı dava konusu edilip edilemeyeceğidir. Bu usul içerisinde yer alan - rayiç bedel tespiti gibi - kesin ve yürütülebilir nitelikte bulunan işlemler, ayrılabilir işlem kuramı ${ }^{116}$ gereğince, sonuç işlem olan pay satışı kararından önce iptal davasına konusu edilebilecekleri kabul edilmelidir. Gerçekten de bir işlemi oluşturmak üzere bir araya gelmiş bulunan çok sayıdaki işlemi bir bütünlük içinde ele almak, onları nihai işlemin bir parçası, unsuru olarak görmek ve sadece sonuç işlemle dava konusu edilebileceğini kabul etmek etkili bir yargısal denetimin önüne geçebilecektir. Her bir işlemin tek tek ele alınarak, hukuki yapıları, etkileri bakımından bir ayrıma tabi tutmak mümkündür. İşte bu fonksiyonu 'ayrılabilir işlem kavramı' ifa etmektedir ${ }^{117}$. Şu halde, pay satış başvurusu neticesinde, payı satışa konu edilecek veya payı satın alacak malik(ler)in ${ }^{118}$, yalnızca rayiç bedel tespitinin - veya ihale kararının - hukuka aykırılığını ileri sürmeleri ve bu kararı otuz gün içinde iptal davasına konu etmeleri mümkün olmakla beraber ${ }^{119}$; Bedel Tespit Komisyonu tarafından tesis edilen hatalı rayiç bedel

114 Payı satışa konu edilen malik, payın satılacağı açık artırmaya izleyici olarak katılabilmektedir. (Uygulama Yönetmeliği md.15/A/4)

115 Ancak, tescil gerçekleşmeden pay satış kararına dava açılması halinde, davanın konusuz kalması tehlikesi söz konusu olabilecektir. Zira, yapılan satış işlemi sonunda, en yüksek bedeli teklif eden katılımcıya satış yapılmasına karar verilmekte ve satış bedelini yedi gün içerisinde banka nezdinde açtırılacak vadeli hesaba yatırması istenmektedir. Bu süre içerisinde satış bedeli yatırılmaz ise pey süren diğer katılımcılara sırasıyla bildirimde bulunularak, satış bedelini yatıran katılımcıya satış yapılmaktadır. (Uygulama Yönetmeliği md.15/A/8) En yüksek bedeli teklif eden katılımcının, satı̧ bedelini yatırmaması ihtimal dahilindedir. Bu durumda ilk satış kararı idarece iptal edilerek, sırasıyla en yüksek bedeli yatıran katılımcılara satış yapılmaktadır. Hiçbir katılımcı tarafından bedelin ödenmemesi halinde ise, yeni bir satış günü belirlenerek satış işlemi tekrarlanmaktadır. (Uygulama Yönetmeliği md.15/A/12) Pay satış kararına karşı tescil gerçekleşmeden önce dava açılması ve yukarıda yer verilen olasılıklardan birinin ortaya çıması durumunda, satış kararı iptal edileceği için açılmış bulunan dava konusuz kalacak; diğer katılımcılara dair alınacak yeni satış kararının da dava konusu edilmesi gerekecektir.

116 Ayrılabilir işlem kuramına göre, yer aldıkları idari süreç ve statülerden bağımsız olarak farklı birtakım hukuki sonuçlar yaratabilen idari işlemlerin, söz konusu statü ve süreçten ayrılarak iptal davasına konu olmaları mümkündür. Celal Erkut, İptal Davasının Konusunu Oluşturma Bakımından İdari Işslemin Kimliği (Danıştay Matbaası 1990) 130.

117 Murat Sezginer, İptal Davasının Uygulama Alanı Bakımından Ayrılabilir İslem Kuramı (1. Bası, Yetkin Yayıncllı 2000) 58.

118 Rayiç bedel tespiti kararı hem payı satılacak hem de payı satın almak isteyen malikin menfaatini ihlal edebilecek niteliktedir. Bu hususta ayrıca $\boldsymbol{b} \boldsymbol{k z}$ "Bedelin Belirlenmesi" başlığımız.

1196183 sayıl Kanun uyarınca amme alacağının tahsil usulü kapsamında gerçekleştirilecek taşınmaz satışı öncesinde, ihaleden ayrılabilir nitelikteki idari işlemlerin ayrıca dava konusu edilebileceği hususundaki benzer değerlendirmeler için bkz. Gül Üstün, İdare Hukuku Boyutuyla 6183 Sayıl Amme Alacaklarının Tahsil Usulü Hakkında Kanun Uygulamalarında Görev Sorunu, (1.Bası, On İki Levha Yayıncilık 2013) 205-206.

Uygulama Yönetmeliği md.15/A/4 kapsamında, maliklere yapılacak tebligatta, satışın yapılacağı yer ve zaman bilgisinin yer alması gerektiği düzenlenmiştir. Ancak uygulamada Bedel Tespit Komisyonu tarafından saptanan pay bedelinin de satıs yer ve tarihiyle birlikte tebliğ edildiği görülmektedir. Bu durumda, itiraz veya dava yoluna başvurma süresinin bu 
tespit işleminin, pay satış kararıyla birlikte davaya konu edilmesi ve hukuka aykırılık iddiasının bu işlemle birlikte ileri sürülmesi de mümkündür ${ }^{120}$. Rayiç bedel tespitine karşı iptal davası açılmış olması, pay satışı kararına karşı dava açılmasına (iptal ve/veya tam yargı davası) engel değildir. Her iki işleme de ayrı ayrı dava açılmış olması ihtimalinde, bu davaların bağlantılı davalar olarak nitelendirilmesi gerekmektedir ${ }^{121}$. Öte yandan, pay satış usulü kapsamında tesis edilen idari işlemlere karşı dava açılmış olması, - davada yürütmenin durdurulması kararı alınmadıkça - pay satış sürecini durdurmayacaktır.

Payı satışa konu edilecek maliklerin, pay rayiç bedelinin hatalı şekilde belirlendiği iddiasıyla açtığı davada, pay satışının idarece belirlenen değerden gerçekleştirildiği ve/fakat mahkemece saptanan rayiç değerin daha yüksek olduğu tespit edilirse, idarenin tazmin yükümlülüğü gündeme gelecektir.

\section{SONUÇ YERINE}

6306 sayılı Kanun’un yürürlüğünden bu yana yaklaşık on yıl geçmiş olmasına karşın ne uygulamada ne de yargı kararlarında Kanun'un uygulanmasına ilişkin tam anlamıyla bir istikrar sağlanmıştır. Bu durum, Kanun kapsamında yer alan ve bu çalışmanın konusunu oluşturan pay satışı müessesi açısından da geçerlidir. Bunda, pay satışına dayanak teşkil eden mevzuatın

tarihten başlayacağına kuşku bulunmamaktadır. Bedel Tespit Komisyonunca belirlenen rayiç bedelin maliklere tebliğ edilmemesi halinde ise, bu süre bedelin öğrenilmesi ananından başlayacaktır.

120 Uyuşmazlık Mahkemesi de böyle bir davanın idari yargı yerinde görülmesi gerektiğini ifade etmiştir. "(D)avacılar vekili tarafından idari yargı yerinde, müvekkillerinin hisselerinin satışı için tespit edilen bedelin düşük olduğundan bahisle söz konusu değer tespitine yönelik işlemin iptali istemiyle; [...] dava açıldığı anlaşılmaktadır. [...] Konuya ilişkin mevzuat hükümleri ile somut olay birlikte değerlendirildiğinde; davacıların hisseli kat maliki oldukları taşınmazın bulunduğu Sitenin 6306 sayıl Afet Riski Altındaki Alanların Dönüştürülmesi Hakkında Kanun uyarınca riskli yapı tespit edilerek yıkıldığı; davacılar tarafından, taşınmazın değerinin tespiti ve ihaleyle satışı sırasında davalı idarenin mevzuata aykırı iş ve işlemlerinin bulunduğu iddiasıla zarara uğradıklarından bahisle, işlemin iptali ve tazminat istemiyle açılan davanın, 2577 sayılı İdari Yargılama Usulü Kanunu’nun 2. maddesi hükmü ve 6306 sayılı Yasanın 6/9 maddesindeki düzenleme gereğince idari yargı yerinde görülmesi gerektiği sonucuna varılmıştır”, Uyuşmazlık Mahkemesi HB, E 2019/585 K 2019/739, 25.11.2019; Aksi yönde isabetsiz bir karar için $\boldsymbol{b k z}$ “[...] (K)at maliklerince 2/3 oranında oy çokluğuyla karar alındığı, paydaşlardan anlaşma sağlayamayan maliklerin $1 / 3$ oranındaki arsa paylarının satışı işlemlerine başlanıldığ 1 , bu amaçla davalı idare tarafından her bir hissedar için ayrı ayrı Tahmin Edilen Bedel Tespit Raporu düzenlenmek suretiyle, davacıların söz konusu arsadaki toplam 12/320 oranına (74,437-m2) isabet eden hisselerinin Bedel Tespiti ve Satış Komisyonu'nca 22.09.2014 tarihinde, günün alım satım rayiçlerine göre tespit edilen $m 2$ birim fiyatı 7.000,00-TL bedel üzerinden ihaleye çıkarıldığı ve 23.09.2014 tarihinde açık arttırma usulüyle anlaşma sağlayan paydaşlara satışının yapıldığı, görülmekte olan davanın ise davacıların hisselerinin satışı için tespit edilen bedelin düşük olduğundan bahisle söz konusu değer tespitine yönelik işlemin iptali istemiyle açıldı̆̆ı anlaşılmaktadır. [...]

Olayda, davacıların yapısının riskli olduğunun belirlenmesi sonrasında davacıların çoğunluk kararına katılmaması üzerine paylarının satışına karar verildiği, bu satış işlemine karşı açılan davanın İstanbul 9. İdare Mahkemesinin 31.12 .2014 tarih ve E:2014/711, K:2014/2517 sayılı kararı ile reddedildiği anlaşılmıştır. Davacıların bu davada ise paylarının m2 birim fiyatı 7.000,00-TL bedel üzerinden ihaleye çıkarılarak satıldığ $1, m 2$ birim değerinin daha yüksek olduğu iddiasına ilişkindir. Bu durumda, idari işlem mahiyetinde olan satış işleminin davaya konu edilerek reddedilmesi sonrasında yapılan ihalede bedelin düşük olduğuna, taşınmazın daha yüksek değerde olduğuna dair itirazın ihaleye yönelik bedele ilişkin olması nedeniyle Adli Yargının görev alanına girdiği sonucuna ulaşılmıştır”, İstanbul BİM 4 İDD, E 2017/706 K 2017/434, 23.05.2017.

121 Bağlantılı davalar hakkında bkz Gül Üstün, 2577 Sayılı İdari Yargılama Usulü Kanununda Bağlantılı Davalar ve Aynı Dilekçeyle Dava Açılabilecek Haller (1. Bası, On İki Levha Yayıncılık 2018). 
lafzının karışık olmasının rolü büyüktür. Mevzuatı eline alan bir kişinin - hatta hukukçunun-, en başta satışın konusunu payın mı, hissenin mi yoksa arsa payının mı oluşturduğunu ilk bakışta anlaması mümkün gözükmemektedir. Öte yandan, mevzuatta sık sık değişiklik yapılması da pay satışına ilişkin uygulamanın ve yargı kararlarının istikrar kazanmasının önüne geçmektedir. Yeni hükümlerin getiriliş amacının anlaşılmasının ve idare ile yargı organının mevcut uygulama alışkanlıklarından sıyrılarak bu değişikliklere uyum sağlamasının zaman alması, hatta bu uyum sağlanmaksın yeni bir değişiklikle karşı karşıya kalınması, pay satışı müessesesine ilişkin istikrarlı bir uygulama ve içtihadın oluşmasını engelleyen faktörlerden bazılarıdır. Bu durumun değişmesi de pek mümkün gözükmemektedir. Zira, mevzuat içerisinde hala, Bedel Tespit Komisyonu ve Pay Satış Komisyonunun teşkili ve görevlendirilmesi, idarece rayiç bedel tespitinin belirlenmesi usulü, payı satışa konu edilecek maliklere yapılacak 'bildirim', pay satı̧ıı için yapılan başvurunun idarece değerlendirilmesi gibi konularda düzenleme eksikliğinin varlığından söz edilebilir. Bu eksikliklerin, kanun koyucunun ve idarenin, - toplantı yapılması ve maliklerce rayiç bedel tespit zamanı gibi konulardaki - bilinçli sessizliği olarak yorumlanması mümkün değildir. Tüm bu hususların, 6306 sayılı Kanun’un uygulanmasını göstermek üzere çıkarılan Uygulama Yönetmeliği’nde açıklı̆̆a kavuşturulması gerekmektedir.

Pay satışına ilişkin olarak mevzuatta var olan bu eksiklikler ile mevzuatın yazımındaki özensizliklerin, hukuki ihtilafların doğmasına yol açması kuvvetle muhtemeldir. Nitekim uygulamada bu durum müşahede edilmektedir. 6306 sayılı Kanun'da düzenlenen pay satış müessesesinin, TMK ve KMK’nın temel prensipleriyle çatışabildiği ve mülkiyet hakkını doğrudan etkilediği hususuyla birlikte düşünüldügünde, herhangi bir hukuki ihtilafın doğumunda mevzuatın ne şekilde yorumlanacağ konusu büyük önem arz etmektedir. Bu çalışmada, 6306 sayılı Kanun kapsamında riskli yapılarda pay (hisse) satı̧sı konusundaki belirsizlikler ile uygulama ve yargı kararlarındaki farklılıklar üzerinden, birtakım çözüm önerileri getirilmeye, hukuki çerçeve çizilmeye çalışılmıştır. Ancak, riskli yapılarda pay satışına ilişkin sürecin, pay satış şartlarının sağlanmasına ilişkin kısmı, maliklerce gerçekleştirilen işlemlerden oluşmaktadır. Maliklerin, sözleşme serbestisi ilkesi ve mülkiyet haklarının beraberinde getirdiği yetkiler çerçevesinde çok farklı anlaşmalar akdetmeleri mümkündür. Buna ek olarak, pay satışına konu olacak hisselerin bulunduğu taşınmazlar, imar hukukunun arazi esaslı olması nedeniyle farklı imar rejimine tabi olmaktadırlar. Bu anlamda, pay satışına ilişkin ortaya çıkması muhtemel sorunların her birinin eksiksiz şekilde tespiti mümkün değildir. Aslında buna gerek de yoktur. Burada önemli olan, ortaya çıkan hukuki ihtilafın çözümünde nasıl bir yaklaşım sergileneceğidir. 6306 sayılı Kanun ve Uygulama Yönetmeliği, 6306 sayılı Kanun’un amacı göz önünde bulundurularak yorumlanmalıdır. Zira, 6306 sayılı Kanun, afet riski altındaki yapılarda ve alanlarda hızlı şekilde dönüşümü sağlayabilmek adına genel hükümlerden (TMK ve KMK) farklı düzenlemeler getirmiş; pay satışı müessesi de bu amaca ulaşmanın bir aracı olarak öngörülmüştür. Bu doğrultuda, araya yargı makamı girmeksizin, idari faaliyet neticesinde pay satışının yapılmasına imkân tanınmıştır. Bu nedenle, kentsel dönüşüm olgusu ve pay satışı müessesesi, riskli yapı malikleri arasındaki bir hukuki ihtilafa indirgenemez. Konunun, afet riski altındaki yapıların 'sağlıklı ve dengeli bir çevrede yaşama hakki’ kapsamında dönüştürülerek kamu düzeninin korunmasına ilişkin bir boyutunun bulunduğu unutulmamalıdır. Bu nedenle, pay satış müessesesine ilişkin olarak ortaya çıkabilecek 
hukuki problemlerin çözümünde, 6306 sayılı Kanun ve pay satışı müessesesinin amacının göz önünde bulundurulması şarttır. 6306 sayılı Kanun gereğince muhalif paydaşların paylarının satılacak olmasının mülkiyet hakkına etki ettiğine kuşku yoktur. Ancak, riskli yapı niteliğindeki binada kentsel dönüşümü talep eden nitelikli çoğunluğa sahip maliklerin de mülkiyet ve sağlıklı çevrede yaşama haklarının korunması gerektiği unutulmamalıdır.

\section{KAYNAKÇA}

Akipek JG, Akıntürk T ve Ateş D, Eşya Hukuku (2. Bası, Beta 2018).

Arpacı A, 'Müşterek Mülkiyette Pay Üzerinde İntifa Hakkı Kurulmasının Diğer Paydaşlara Etkisi' Marmara Üniversitesi Hukuk Fakültesi Hukuk Araştırmaları Dergisi (2014) 20(1) 981-988.

Ayanoğlu T, Yapı Hukukunun Genel Esasları (1. Bası, Vedat Kitapçılık 2014).

Çetiner B, 'Kentsel Dönüşüme İlişkin Yargıtay 18. Hukuk Dairesinin 04.11.2015 Tarihli Kararına İlişkin İnceleme ve Değerlendirmeler' İstanbul Üniversitesi Hukuk Fakültesi Mecmuası (2016) 74(1) 233-240.

Demirkol S ve Bereket Baş Z, 'Kentsel Dönüşümün, 6306 Sayılı Yasa Kapsamında Hak ve Özgürlükler Açısından Ele Alınması' (2013) (108) Türkiye Barolar Birliği Dergisi 23-70.

Erkut C, İptal Davasının Konusunu Oluşturma Bakımından İdari İşlemin Kimliği (Danıştay Matbaası 1990).

Germeç ME, Kat Mülkiyeti Hukuku (10. Bası, Seçkin Yayıncılık 2021).

Gürsel E, Kentsel Dönüşüm (1. Bası, Adalet Yayınları 2018).

İnal E, Kentsel Dönüşüm Hukukunda Riskli Yapı (1. Bası, On İki Levha Yayıncılık 2017).

Kaplan O, İdare Hukuku Yönünden Afet Riski Altındaki Alanların Kentsel Dönüşüm Süreci (1. Bası, On İki Levha Yayıncillk 2017).

Karadabağ H, Mülkiyet Hakkı Çerçevesinde Kentsel Dönüşüm (1. Bası, Legal Yayıncılık 2020).

Koroğlu Ö, İmar Hukukunda Yapı Kavramı ve Temel Yapı Belgeleri (1. Bası, On İki Levha Yayıncılık 2017).

Kulaklı E, 'Türkiye’de Kentsel Dönüşüm Rejimini Ortaya Çıkaran Nedenler, Uygulaması ve Özel Hukuk Alanına Bazı Etkileri’ in Furkan Beşel, Fatih Yardımcıoğlu ve Hakkı Bağcı (eds), Uluslararası Politik, Ekonomik ve Sosyal Araştırmalar Kongresi ICPESS 2017 Bildiri Özetleri Kitabı (Kaşköprü Yayınları 2017).

Kurşat Z, '6306 Sayılı Afet Riski Altındaki Alanların Dönüştürülmesi Hakkında Kanunun Özel Hukuk Alanındaki Etkileri' iç Melikşah Yasin ve Cenk Şahin (edr), Kentsel Dönüşüm Hukuku (2. Bası, On İki Levha Yayıncılık 2015).

Oğuzman MK, Seliçi Ö ve Oktay Özdemir S, Eşya Hukuku (18. Bası, Filiz Yayıncılık 2015).

Oy O ve Nazik S, Kentsel Dönüşüm Kapsamında Rezerv Yapı Alanı - Riskli Alan ve Riskli Yapılar (1. Bası, Beta 2014).

Öngören G, Kentsel Dönüşüm Hukuku (Öngören Hukuk Yayınları 2013).

Öz T, 'Kentsel Dönüşüm Kanunu Çerçevesinde Yapı Maliklerinin Üçte İki Çoğunlukla Alacakları Kararın İçeriğinin Amaca Göre Sınırlanabilmesi’ İstanbul Kültür Üniversitesi Hukuk Fakültesi Dergisi (2016) 15(1) 391-402.

Özmen ES ve Ayar A, 'Kentsel Dönüşüm Uygulamalarında Eski Arsa Payından Paylı Mülkiyete ve Yeni Arsa Payına Uzanan Süreçte Yanılgılar’ Türkiye Barolar Birliği Dergisi (2021) (156) 107-134.

Özmen ES ve Aydın GS, ‘6306 Sayılı Kanun Uyarınca Paylı Mülkiyet Sürecinde Paylaşma Davasına (İzale-i Şuyu) İlişkin Hüküm ve Sonuçlar’ Legal Hukuk Dergisi (2018) (188) 35-76.

Özmen ES ve Çakmak B, ‘6306 Sayılı Yasa Uygulamalarında Arsa Payının Düzeltilmesi Davasına İlişkin Hüküm ve Sonuçlar’ İstanbul Barosu Dergisi (2013) 87(5) 725-750. 
Özmen ES ve Şengül M, Kentsel Dönüşümde Kat Mülkiyeti Uygulamaları ile Sinırlı Ayni Haklar ve Şerhler (1.Bası, On İki Levha Yayıncılık 2018).

Özmen ES ve Yüce MB, 'MK “Madde 700” Hükmünce Pay Üzerindeki İntifa Haklarının Paylı Halin Giderilmesi Davalarına İlişkin Hukuki Sonuçlar’ İstanbul Barosu Dergisi (2007) 81(3) 949-970.

Özsunay E, ‘6306 Sayılı Kanun ve Kentsel Dönüşüm Uygulamalarına İlişkin Düşünceler’ İstanbul Barosu Dergisi (2014) 88(6) 15-51.

Sancakdar O, İmar Hukuku (1. Bası, SBNET Uzaktan Eğitim ve Yayıncılık 2020).

Sezginer M, İptal Davasının Uygulama Alanı Bakımından Ayrılabilir İşlem Kuramı (1. Bası, Yetkin Yayıncılık 2000).

Şimşek S, Türkiye’de Kentsel Dönüşüm Uygulamaları (4. Bası, Seçkin Yayıncılık 2016).

Türk Hukuk Kurumu, Türk Hukuk Lügatı (1. Bası, Başbakanlık Basımevi 1991) (129).

Üstün G, 2577 Sayılı İdari Yargılama Usulü Kanununda Bağlantılı Davalar ve Aynı Dilekçeyle Dava Açılabilecek Haller (1. Bası, On İki Levha Yayıncılık 2018).

Üstün G, Kentsel Dönüşüm Hukuku (1. Bası, On İki Levha Yayıncılık 2014).

Üstün G., İdare Hukuku Boyutuyla 6183 Sayılı Amme Alacaklarının Tahsil Usulü Hakkında Kanun Uygulamalarında Görev Sorunu (1.Bası, On İki Levha Yayıncılık 2013).

Yağcı K, 'Kat Mülkiyetine Tabi Binaların Kentsel Dönüşüm Çerçevesinde Yıkılıp Yeniden Yaptırılmasında Aranacak Karar Nisabı’ iç Tufan Öğüz ve Baki İlkay Engin (edr), Medeni Hukuk Alanındaki Güncel Yargıtay Kararlarının Değerlendirilmesi Sempozyumları Cilt 1 Eşya Hukuku (1. Bası, On İki Levha Yayıncilık 2016).

Yasin M, 'Kentsel Dönüşüm Uygulamalarının Hukuki Boyutu' Türkiye Barolar Birliği Dergisi (2005) 18(60) 105-137.

Yaşar HN, İmar Hukuku (1. Bası, Filiz Kitabevi 2008).

Yazıcı G, Yargı Kararları Işığında Kentsel Dönüşüm, Riskli Yapılar ve Yargısal Denetim (1. Bası, Seçkin Kitabevi 2018).

Yıldırım R, ‘İdareye Taşınmaz Mal Kazandıran Bedelsiz Terk, Devir ve Temlikler’ KTO Karatay Üniversitesi Hukuk Fakültesi Dergisi (2016) 1(2) 13-22. 